\title{
ROENTGENOLOGIC DIAGNOSIS OF THE CANCER IN THE MAXILLARY SINUS
}

\author{
By \\ SHIGEAKI AIHARA \\ Department of Oto-Rhino-Laryngology, Chiba University, \\ School of Medicine (Director: Prof. T. Kitamura)
}

Roentgenograms of 30 cases of the operated maxillary cancer are compared with the histological findings in the large section preparates. Results as follows :

1) The maxillary sinus. The dense shadows with the bright portions and discontinuous contours of the sinus walls are the pathogmotical findings. The destruction of the posterior wall and the pterygoid process are visualized by means of the axial views, Rhese's technic and horizontal or sagittal tomography.

2) The almost similar findings are found in the ethmoid portion.

3) The sphenoidal sinus has to be examined by means of the axial views and the frontal tomography.

4) The dense shadows sometimes were found in the frontal sinus, but no invasion of the cancer in this series.

5) The nasolacrimal duct was visualized through the injection of $40 \%$ moljodol $(0.3 \mathrm{cc})$. Its abnormality revealed the invasion of the cancer in the anterior superior portion of the nasal cavity.

6) The arteriography of the external carotid reveals the destruction of the bony walls according to the dislocation of the stem and its branches.

The existence of the cancer in the maxillary sinus today is easily diagnosed, but the destruction of the bony wall and its grade may be only dem. onstrated through the adequate technic according to each wall of the sinus, so that the necessary and complete diagnosis will be only successful by means of some films, taken by adequate technics to the cases.

\section{上顎癌 の $\mathrm{X}$ 線診 断}

千葉大学医学部㷅奥㸶㬋科学教空 (主任: 北村武教授)

$\begin{array}{lll}\text { 相 原 } & \text { 坮 明 } \\ \text { 故 }\end{array}$
目次
1 緒言
II文献的考察
A）単純撮影その他
B）その悪性腫焬への応用
C) 断周 撮影
D）外頸動脈造影撮影

III研究方法
A) 単純撮影
B) 断層撮影

C) 误道造影撮影

D）外頸動脈造影撮影

N 研究成䊼
A）手術 - 摘出唀本 ・大切片標本所見
B）単純撮影と手術所見との比較
1) 後頭前頭撮影
2) 後頭㖽撮易
3) 軸位撮影
4) Rhese 氏法撮影
C）断層撮影々手術所見との比較 
1) 前頭断層撮影

2) 矢状断層撮影

3)水平断㬝撮影

D）涙道造影撮影と手術所見との比較

E）外顠動脈造影撮影と手術所見との比較 V，総括並びに考按
A)上顎洞陰影
B）上旗洞骨壁
C) その他の副舅洞
D）鮙腔内各部
E）翼状突起と煩骨
F）外頸動脈と上䫛润各壁の関係

V1 結 語

主要参考交献

付国

\section{I. 緒訔}

上顎癌の診断には従来病歴，宜鏡検查の他に X 楾写 真，更には試験的開洞術等が用いられ，診断の確定には 試跧切除による組織学的検査を必要としていた，近年， 超音波診断法等の新技術の導入並びに諸種診断法の進步 により，上頡癌の診断は次第に容易且つ確実となつて来 たが，その中に占める X 線診断法の位固は依然として 大きいものがあり，特にその准展範围の決定には欠かせ ないものである．X 線診断法の耳鼻咽喉科領域への庆 用の初期においては，上顎癌の診断に用いられたものは 後頭前頭・後頭顗撮影であり，その後軸位・斜位撮影等 の案出があり，更に第二次世界大戦直前での断層撮影法 の実用化から，戦後でのそれの目覚ましい普及まで進步 は絶点間ない，現在，上顎癌の診断に一般に用いられて いるものは後頭前頭 ・後頭匵撮影に加えて前頭断層撮影 である、しかし，これ等の撮影法では番鏡検查で知り難 い上顎洞媵壁及びその附近への腫廈の侵翼状態を観察し 難く, 近年 $\mathrm{X}$ 線以外の彭断法の 導入上は別に $\mathrm{X}$ 線写 真利用によるこの方面の開拓が各地で試みられており， 所層撮影法では矢状・水平・回芸・斜位浙㞗等種々の撮 影法の発表が行われ，又，外頸動脈撮影法のこの領域へ の応用る報告されているが，多くは断片的なものであ る.そこで私は更めて上顎癌の X 線䛦断法を体系化す

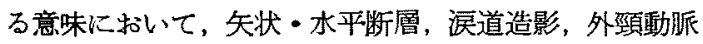
造影撮影をる加えた諸種 X 線撮影法の応用に上る上䫑 癌の竛断法に就いて研究を行い，些がの知見を得たので ここに報告する。

\section{II. 文献的考察}

A) 単純撮影その他

舅副鼻腔領域への $\mathrm{X}$ 線の応用は既に X 線の発見さ れた 1896 年に Scheier が頭部の射創患者に側位撮影法 を用いたのに始る。その後 Meyer (1898) は上顎肉腫 の大きさを側位撮影を用いて詳細に測定し，Winkler (1902) も側位撮影を用いた研究を行つている，次で Haegeler (1904) は矢状位撮影法を考案発表したが，同 年 Goldmann は矢状位撮影法に就いて更に詳しい報告 をしており，彼等は側位撮影では左右の鼻副鼻腔が重る ために左右の観察が不十分であるのに対して，矢状位撮 影では左右が別々に描出される利点のある事を指摘して いる．この二つの撮影法は時代の释過と共にその研究が 盛えとなり，撮影法の改善之 X 線機械の改良により次 第に鮮明な像が得られるょらになつて, 病的変化の診断 に大きな洒值を持つて来た．即ち Goldmann と Killian (1907) が副鼻洞炎にこの撮影法を応用し，健側と比べ て患側の陰影增強を指摘している。 その後も Coakley (1906), Caldwell (1907), Albrecht (1908), Peyser (1909) 等の研究があり，彼等は一様に副鼻洞资の診断 には X 線写真は重要な補助的診断法であると云つてお り, Peyser の如きは疑いむなく必須の診断法であると 述べている。

蝶形洞は 側面撮影で鮮明に描出されていたが，左右 陰影が重つて了5欠点があつた。この事は後に Haike (1911) あ指摘している通りである。そこで Küttner (1908) は矢状位撮影で蝶形洞を描出しよ5として屍体 を使つて水銀を洞内に注入して撮影した処，洞底は水平 陰影として半然と現れたが，率中隔と交文しており襒骨 洞とも重り，しかもこの方法では生体に応用する事は不 能であり，Albrecht（1908） あ矫状位撮影での蝶形洞 の描出は不能であると述べている，処が，Siebenmann (1907) は小フイルムを口内に挿入，頭頂より X 線を投 射する軸位撮影法を発表し蝶形洞の観察を行い，Spiess

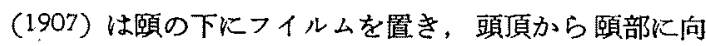

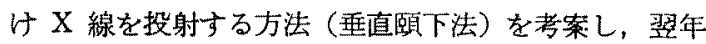
には Pfeiffer が Spiess の方法と逆の方向からの X 線 投射の方法（願下垂直法）を行い，両法の比較を行つて いる．即ち，前者では蝶形洞前部と下顎骨が重るので下 顎骨を前万に描出せねばならず，後者ではフイルムと蝶 形洞の距離が大きくなるので像が拡大されると述べてい る.この撮影法は頭蓋底及じ蝶形洞の観察法として相些 な価值が認められた。しかし，当時は X 線装惪やその 
附属品が余り進歩していないために十分な効果を示す事 か゚できなかつた，かくて，Pfahler (1921) と Knick (1923) が口腔内力セツテを考案し，蝶形洞の鮮明な影 潒を得るに至つた，我国でる松井・義江が注目し，義江 （1940）と橋本（1940）が夫々独自の口腔内力セッテを 考案し，蝶形洞炎の診断に応用して相当の効果を挙げて いる.Pfeiffer (1916) によれば蝶形洞描出を目的に考 案された軸位撮影法もその後の研究により全副門洞の描 出が可能であり，洞の前後及び左右方向の拡り並びに壁 の観察が可能で, 特に前頭洞の観察では後頭前頭撮影で 欠損しているょうに見觉る洞をこの方法で観察でさると 述べている.

一方, Rhese (1910) は節骨蜂桌と蝶形洞観察を目的 として斜位法を試み，Pfahler（1917）は別に上凝洞観 察のための斜位法を考案し，洞前・下壁の観察，特に䅈 からの感染の疑いのある場合の観察に適し，又蝶形洞の 陰影を眼窝の軟部組織を通して投影できると云つてい る：更に Coalwin（1925）も独自の斜位法を用いて視 神経管の計測を行つている.

この他, 'Waters (1915) は既に Caldwell と killian 飞よつて始められた後頭前頭撮影法の変法として頭位の 僅かな変化火より各副番洞への側頭骨錐体部隆影の重鲳 による除影の不鮮明化を除く事に成功した。

又, Sicard (1922) は沃度油を上䫑癌患者の上顎洞に 注入亡，造影剂の使用に上る腫婸の映像把握を初的て試 みた，更に Fraser (1926) る同様な試みを行い，同年 そProetzは置換法の利用による副番洞への造影威の注 入を行っている.

涙道に造影剂を初めて注入したのは Ewing (1909) で, その後 Aubaret (1911)・Szily (1914)・ Gaugelen (1918) - Campbell (1922) ・ 早野 (1922) 等が各種の造 影剂を注入し，その狭窄・摭張・走行異常等の発見に努 めた.リピオドールの発見後は Hoeve (1925)・Stedefeld (1927) • 中村 (1928) • Unterberger (1931) • 武藤 (1932) ・ 畑 (1935) - Spackmann (1938) 等多くの研究 がなされれていが，本村 (1958) は40\%モルヨドール を注入し，種々の鼻副鼻腔疾患に扣ける涙道の状態尤調

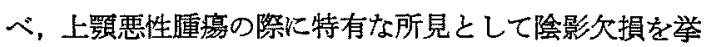
げ，大多数に执いて狭窄・内方王排が見られたと報告し ている.

B）その悪性腫疸への応用

上顎覀性腫瘕の研究に X 線を初めて応用したのは前 述の如く meyer (1898) であるが，彼は上顎肉腫の大
きざ側位撮影法を用いて測定したに過きない，その 後，上顛悪性腫場への応用は Graupner (1912)•Passow (1925) 等によつて行われている. Houser (1933) は上

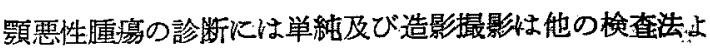
り以上に重要であると云っており，Pfahler (1940) 性 上顎癌の X 線所見として, 奥副鼻腔の陰影堌強・骨影 の㹡大と崩壊・造影剂による軟部組織の不規則輪厗を举 げ，前述の諸種撮影法の組合をによる診断法を推势して いる.

本城 (1940) は後頭前頭 撮影での上顎隆起の 影像を TM 線之呼び，悪性腫境の際にはとれの消失が：見られ 診断上重要な示針となると述ぺている.吉川（1941）は 上頭洞壁は X 線に上り切線的に投影される時最す鲜明 に描出されるとし， Rhese の始めた 斜位法で上哿洞側 後壁が切線的に投影されるので，この方法はこの部の観 察に適していると述べ，又彼は尰厦に上り陰影增強をき たした上顎洞影像は盾晹の侵算が進み骨融解をきたすと 明澄化すると云う。これに就いては山本 (1947) も同様 の見解を持つているが，この場合骨融解があつても煩部 腯脹の見られるものでは陰影が增強すると彼は付け加え ている. Gilmore (1956) は上顎 悪性 腫痬の陰影瀑度 はポリープより濃く，骨腫より淡いと云つているが， Gordon (1955) は陰影の 濃度からそれが悪性腫痬によ るものか炎症によるものかは不明であると述へ，更に彼 は Graham (1951) が悪性腫瘍では一側性の洞陰影增 強を示すと云つている事と，Haas (1951) が上顎覀性庫 㿋の際に前頭洞に骨粗鬆や硬化が多く見られると云つて いる事を否定している.

一方，山本（1956）は上顎悪性腫㔠患者儿上頡洞造影 撮影を行い，特改的な陰影を得たと述べ，浅井 (1958)・ 服部 (1962) も上顎癌の早期診断に同撮影が重要な意義 を持っとしている.

\section{C) 断層撮影}

断層撮影を最初に試みたのは Bocage (1921) で, 深 部 X 線照射量の測定に利用した。しかし，実際的な応 用はV Vallebona (1930) が頭蓋の X 線的研究化用い, 単 粁撮影で見られる陰影の重畳を除く事に成功した事を壦 矢とする、しかる，これが耳鼻咽喉科領域における最初 のものである．以来，断層撮影は主に頭部・咽喉・胸部 に执いて研究が行われて括り，鼻副鼻腔領域に执いては More (1938) は䇫骨洞の, Cone (1939) は副鼻洞子球 後性視神経炎の関係汇関する，Epstein (1942) は蝶形 洞の研究に断層撮影を用いている. Holvey (1944) は 
成人屍体の断面之断層写真を比較し，その所見の一致す る事を詳細仁述，更に上顎演・副番洞炎に応用し，洞 壁の輪颜が他の撮影方法より明膫に示され，診断上極め て有意義であり，特に上顎腫晹の拹りを知る上には断層 撮影がよりい方法であると推等している，第二次世界 大戦終了後, 鼻副窃腔領域に打方断層撮影の研究は 益々盛んとなり，Reynaud (1949)・Prevedi (1950)・ Stanislow (1953) • Psenner (1953) - Carini (1954) • Sichel (1957) その他によつて行われているが, Dargent (1948) - Ennuyer (1951) ・ Baclesse (1952) は夫々上顎 腫場の診断と治療計画の上で断層撮影は必須のものであ るとしている. 又, Boschet (1954) は副鼻洞の系統的 断層撮影の必要性を強調し, 診断には眼窩縁を基淮に少 くとも四層の断層写真が必要であると述べている，我国 でもこの頃から鼻副鼻腔疾患特に上頡腫瘍への断層撮影 の応用が活發となり，野中（1953）は断層撮影で頭部各 断面の形態学的所見を説明し，松田・笹尾 (1954) は上 顠癌仙応用し, 骨久損の判定は容易であり, 尰瘍の侵蝕 程度をより明確に知り得，これにより手術法・手術範围 の決定に資する所大であるとしている，更に，高須賀 (1957)・太田 (1958) は単純撮影で恃困難な翼状突起及

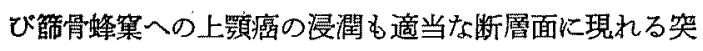
起輪廓の不鮮明及び䗋窂壁・隔壁の崩猡像により診断が 容易になると述べている，鼻副鼻腔領域への断層撮影は その創始期上り前頭・矢状断盾面の研究が行われている が，大多数は前頭面のるのであつた。 所が，これでは描 出困難な上顎洞後壁・翼口蓋窝附近の 描出に関する研 究が次第に行われるよらになつた。即ち, 浅井・太田 (1958)，Dodd ・網野・太田 (1959), 服部 (1962) 等は 矢状断層撮影を行い，左右雨側を同一面に描出できな い欠点はあるが，前後方向特に上项洞前・後壁, 翼状突

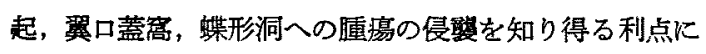
触れている，一方，片桐 (1954)・浜崎（1961）は回転 横断撮影を，佐藤 (1960) は水平断層撮影を行い，上顎 浭场の水平面的拡り特に上顎洞後壁 - 翼状突起 - 蝶形洞 の状態を知り，吉井 (1961) は斜角断層撮影を行い, 上 䫑洞視後壁の影像を鮮明に描出した。

\section{D) 外頸動脈造影撮影}

血管造影は 1923 年以来動物を用いて幾つかの 研究が 行われていたが，人間への応用は Moniz (1927) が脳 血管に行つたのが最初であり, 彼は当時の造影㓣が脳障 害をきたすのでヨードナトリウムを用いた所，これは造 影力は強いが局所障畫る強く，次で彼（1931）はトロト
ラストを用いた。この造影郕は副作用もなくょり早ぐ血 管系を通過するために，Löhr (1932)・Tönnis (1933) 等を始め一般に使用されるようになつた。しかし， Eckström（1838）がトロトラストによる血管周囲の肉 芽腫形成例を報告したのに始り同様の報告が相次いだの で, Hämmerli (1939) はてエチルトリヨードステフリ ンを用い，その毒性の殆どない事を証明し，その後尃ら これが用いられる上らになり，現在に至るもそれと同類 の各種の有機ヨード製㸤が賞用されている.

脳血管即ち内頸動脈造影は脳内矣患の䛦断に必須のむ のとして数十年前より日常に行われているが，畺副鼻腔 領域の血管即ち主に外頸動脈造影は未だ殆ど行われてな く，交献上僅かに数例淿過ぎい. Schrudde (1957) は上颚洞附近の腫湯患者にウログラフインを用いて本法 を行い，上顎洞後方に批ける血管に富んだ腫瘍の診断

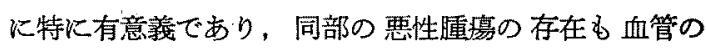
走行異常から知り得ると報告して扣り，Scheunemann （1957）は屍体に本法を用い，外頸動脈領域の 変異は他 部血管領域のそれよりる少い事を述へ，生体にる応用し て経皮的注入法も可能であると語つている，更に，彼 (1958) は浅側頭動脈及び 顔面動脈の個々の造影法を発 表した. Arslan (1959) は鼻部の膠原病患者に本法を行 い，㓵動脈末端が「mousetail」様の特殊陰影を示す事 を指摘している.

\section{III. 研究方法}

昭和 36 年 1 月から 37 年 12 月までの二年間に 千莱大 学医学部附属病院で 連熄摘出術を行つた上顎癌患者 30 例保, 術前次の X 線撮影法を施行し，その X 線写真 所見々手術・摘出構本・大切片 標本 所見々比較 検討乙 た. X 線撮影装圈は東芝故射線株式会社製 DRX 81 型 を使用した。

\section{A) 単純撮影}

1) 後頭前頭撮影 $\left(62_{\mathrm{K}} \mathrm{V}_{\mathbf{P}}, 100 \mathrm{~mA}, 1.0\right.$ sec., 距離 $100 \mathrm{~cm}$, ブッキーブレンデ使用)

2) 後頭頃撮影 $\left(66_{\mathrm{K}} \mathrm{V}_{\mathrm{P}}, 100 \mathrm{~mA}, 1.5 \mathrm{sec}\right.$., 距離 100 $\mathrm{cm}$, ブッキーブレンデ使用)

3）軸位撮影（頤下垂直法）（64 K $\mathrm{V}_{\mathrm{P}}, 200 \mathrm{~mA}, 1.5$ sec., 距離 $100 \mathrm{~cm}$,リスフォルムブレンデ使用)

4）斜位撮影（Rhese 氏法）（66KVP $, 100 \mathrm{~mA}, 1.5$ sec., 距離 $100 \mathrm{~cm}$, ブッキーブレンデ使用)

B) 断層撮影

1) 前頭断層撮影 $\left(6 \mathrm{~K}_{\mathrm{K}} \mathrm{V}_{\mathrm{P}}, 100 \mathrm{~mA}, 3.0 \mathrm{sec}\right.$., 移動角 度 $45^{\circ}$, 距離 $100 \mathrm{~cm}$, ブッキーブレンデ使用) 
腹臥位で独逸水平面をフイルムに垂直にし，次の四面 で撮影した。

1 面：2 面より $1.0 \mathrm{~cm}$ 前方の面. 眼简前部・前篣骨 蜂䆵前部・上顎洞前部・鼻腔前部・鼻涙管・荬 槽突起前部を通る。

2 面：外眼角を通る面. 眼䈑中央部・前節骨蜂笨後

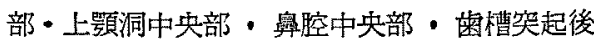
部・煩骨前部を通る。

3 面： 2 面上り $1.5 \mathrm{~cm}$ 後方の面. 眼窝後部・後節骨 蜂笨・上顎洞後部・鼻腔後部・ 口蓋後部・煩骨 後部を通る。

4 面：外眼角と外耳道前緑を結ぶ線上で後 $1 / 3$ を通 る面. 蝶形洞・率腔最後部・翼状突起を通る.

2) 矢状断層撮影 $\left(6 \mathrm{O}_{\mathrm{K}} \mathrm{VP}, 100 \mathrm{~mA}, 2.0 \mathrm{sec}\right.$., 移動角 度 $45^{\circ}$, 距離 $100 \mathrm{~cm}$, ブッキーブレンデ使用)

腹臥位で頭部矢状面をフイルムに平行に患側を下にし て次の四面で撮影した。

1 面：患側外眼角を通る面．煩骨を通る。

2 面：患側眼窝中央を通る面．上顎洞中央部・翼状 突起を通る。

3 面：患側内眼角を通る面. 䦾骨蜂巢・蝶形洞・鼻 腔を通る。

4 面： 健側眼窝中央を通る面.

3）水平断層撮影 $\left(74_{\mathrm{K}} \mathrm{V}_{\mathbf{P}}, 100 \mathrm{~mA}, 2.0 \mathrm{sec}\right.$., 移動角 度 $45^{\circ}$, 距離 $100 \mathrm{~cm}$, ブッキーブレンデ使用)

腹臥位で顔面を前方に出し独勉水平面をフイルムに平 行にして次の四面で撮影した。

1 面：鼻腔底部を通る面. 上頻洞下部・鼻腔最下部・ 翼状突起下部老通る。

2 面： 1 面と 4 面間の下 $1 / 3$ を通る面. 上䋶洞中央 部・奥腔下部・翼状突起中央部・煩骨最下部を 通る。

3面： 1 面と 4 面間の上 $1 / 3$ を通る面. 上顎洞中央 部・鼻腔中央部・翼状㔖起上部・煩骨下部を通 る。

4 面：眼䈑下縁を通る面. 上顎洞上部・番腔上部・ 煩骨中央部・穊骨蜂黛下部・蝶形洞下部を通 る.

C) 洰道 造影撮影 [ $64_{K} V_{P}$ (側面 $60 \mathrm{KVP}$ ), 100 $\mathrm{mA}, 1.0 \mathrm{sec}$ (側面 $0.8 \mathrm{sec}$ ), 距離 $100 \mathrm{~cm}$, ブッ キーブレンデ使用了

$40 \%$ モルヨトール0.3cc 注入器を用いて下滬点よ り注入し，正面及び側面撮影を行つた。
D) 外頸動脈造影撮影 [74 $4_{K} V_{P}$ (側面 $70_{K} V_{P}$ ), $100 \mathrm{~mA}, 1.0 \mathrm{sec}$., 距離 $100 \mathrm{~cm}$, リスフォルムフ。 レンデ使用]

腄瘖摘出術に際し予め露出した外頸動脈起始部より末 端へ $1 \sim 2 \mathrm{~cm}$, 㒀れた部位に, 長さ $4.0 \mathrm{~cm}$, 内径 $0.8 \mathrm{~mm}$ の注入針を刺入，76\%ウログラフイン $10 \mathrm{cc}$ をできるだ け早い速度で注入し，正面及び側面撮影を行つた。

\section{IV 研 究成績}

A) 手術 - 摘出 標本 - 大切片標本 所見（以下手術 所見々略寸）（表 1)

上顎洞各壁は主に大切片標本所見に頼り，足りない所 を摘出標本所見で補つた，表中（H）は骨と欠損のある

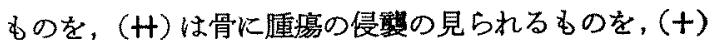

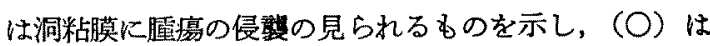
以下全て侵裂のない事を示す

節骨蜂集は主に摘出標本所見により，手術所見で補足 した（H）は腫瘍の侵警の著しいものを（十）はそれ の軽いものを示寸．蝶形洞・前頭洞は専ら手術所見に賴 り，(H) は洞骨壁の久損の好るものを示す

梨状孔縁・下鼻介・中奥介・淚道・鼻底は摘出標本所 見により（卅）は骨崩壊の見られるるのを（）は）骨

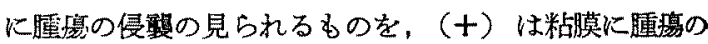

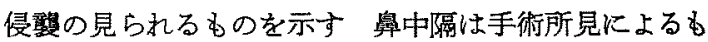
のである。

翼状突起・煩骨は主に摘出標本所見に頼り，手術所見 で補つた，翼状突起では（十）は腫堭の侵警の見られる

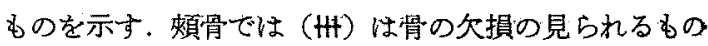

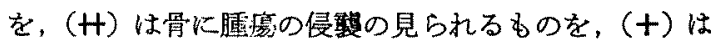
周辺骨に庫瘍の侵襲の見られるものを示す。

眼球除去では（十）が除去を示し，（O）は除去しな い事を示寸。

B）単純撮影所見と手術所見との比較

1) 後頭前頭撮影 (表 2)

（一）は骨・軟部陰影飞断絶・消失のあるるのあるい は含気腔陰影の透明化を，(世列）は骨・軟部陰影の厚化 高度なものを（H）はそれの中等度なものを，(十は それの軽度なるのを（土）はそれの疑わしいるのを，

（○）は正常所見を示す 不規則性は（O）と（一）を雨 極端とし，各例での両端の差を以て示した．対眎として 対側を使用した，他の撮影法においても同様である。な 拈，前頭洞の項の斜線は洞不在を示す

a)上頸洞陰影

不規則性 3 が 1 例, 2 が 9 例, 1 が17 例， 0 が 3 例で， 
表 1 手術・摘出標本・租穖所見

\begin{tabular}{|c|c|c|c|c|c|c|c|c|c|c|c|c|c|c|c|c|c|c|c|c|c|c|c|}
\hline \multirow{2}{*}{$\begin{array}{c}\text { 症 } \\
\text { 番号 }\end{array}$} & \multicolumn{2}{|c|}{ (9) } & \multirow{2}{*}{ 性 } & \multirow{2}{*}{$\begin{array}{l}\text { 年 } \\
\text { 令 }\end{array}$} & \multirow{2}{*}{$\begin{array}{l}\text { 患 } \\
\text { 側 }\end{array}$} & \multicolumn{2}{|c|}{ 上 } & 䫴 & 洞 & \multicolumn{2}{|c|}{ （壁） } & \multirow{2}{*}{ 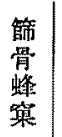 } & \multirow{2}{*}{$\begin{array}{l}\text { 蝶 } \\
\text { 形 } \\
\text { 洞 }\end{array}$} & \multirow{2}{*}{$\begin{array}{l}\text { 前 } \\
\text { 頭 } \\
\text { 洞 }\end{array}$} & \multirow{2}{*}{$\begin{array}{l}\text { 梨 } \\
\text { 桨 } \\
\text { 孔 } \\
\text { 粶 }\end{array}$} & \multirow{2}{*}{$\begin{array}{l}\text { 下 } \\
\text { 番 } \\
\text { 介 }\end{array}$} & \multirow{2}{*}{$\begin{array}{l}\text { 中 } \\
\text { 䱣 } \\
\text { 介 }\end{array}$} & \multirow{2}{*}{$\mid \begin{array}{c}\text { 學 } \\
\text { 源 } \\
\text { 管 }\end{array}$} & \multirow{2}{*}{$\mid \begin{array}{l}\text { 番 } \\
\text { 底 }\end{array}$} & \multirow{2}{*}{$\begin{array}{l}\text { 骨 } \\
\text { 中 } \\
\text { 隔 }\end{array}$} & \multirow{2}{*}{$\begin{array}{l}\text { 琶 } \\
\text { 桨 } \\
\text { 笑 } \\
\text { 起 }\end{array}$} & \multirow{2}{*}{$\begin{array}{l}\text { 頝 } \\
\text { 骨 }\end{array}$} & \multirow{2}{*}{$\begin{array}{l}\text { 眼 } \\
\text { 球 } \\
\text { 除 } \\
\text { 去 }\end{array}$} \\
\hline & 多 & 名 & & & & 上 & 下 & 内 & 外 & 前 & 後 & & & & & & & & & & & & \\
\hline 1 & I & $\mathrm{U}$ & $\hat{o}$ & 40 & $\mathrm{R}$ & $H$ & 10 & $\mathrm{HH}$ & $H$ & $H$ & $H$ & $H$ & 0 & 0 & $\mathrm{HH}$ & HI & + & Ht & $H$ & 0 & 0 & 0 & 0 \\
\hline 2 & $\mathrm{H}$ & & q & 53 & L & tI & 0 & $H$ & $H$ & $H$ & H & 0 & 0 & 0 & $H$ & $H$ & + & $H$ & + & 0 & 0 & $H$ & 0 \\
\hline 3 & $\mathrm{M}$ & & $q$ & 62 & $\mathrm{~L}$ & 0 & $\mathrm{HH}$ & 0 & $H$ & 0 & $\mathrm{HH}$ & 0 & 0 & 0 & 0 & 0 & 0 & 0 & $\mathrm{HH}$ & 0 & + & 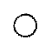 & 0 \\
\hline 4 & $\mathrm{H}$ & $\mathrm{K}$ & $\hat{\mathrm{d}}$ & 50 & $\mathrm{R}$ & $\mathrm{HH}$ & $\mathrm{HH}$ & $H$ & $\mathrm{HH}$ & $\mathrm{HH}$ & $H$ & $t$ & 0 & 0 & $H$ & $H$ & $H$ & 0 & $H$ & 0 & + & H & 0 \\
\hline 5 & $\mathbf{M}$ & $O$ & $\delta$ & 58 & L & H & $\mathrm{H}$ & $\mathrm{H}$ & $H$ & $\mathrm{HH}$ & $H$ & $H$ & 0 & 0 & $H$ & $H$ & $H$ & $\mathrm{HH}$ & $\mathrm{H}$ & 0 & 0 & $H$ & + \\
\hline 6 & $\mathrm{O}$ & $\mathrm{M}$ & $\hat{\delta}$ & 49 & L & mf & 0 & $\mathrm{HH}$ & $H$ & $\mathrm{HH}$ & $H$ & + & 0 & 0 & $\mathrm{HH}$ & $H$ & + & + & $H$ & 0 & 0 & + & + \\
\hline 7 & $\mathbf{H}$ & $\mathrm{S}$ & $\hat{\delta}$ & 61 & $\mathrm{R}$ & 0 & H & $\mathrm{HH}$ & $H$ & 0 & $\mathrm{HH}$ & $t$ & 0 & 0 & $H$ & $H$ & $H$ & + & $\mathrm{H}$ & 0 & + & $H$ & 0 \\
\hline 8 & $T$ & $\mathrm{~N}$ & 3 & 60 & $\mathrm{R}$ & $\mathrm{mt}$ & + & $H$ & $H$ & H & $\mathrm{H}$ & $H$ & 0 & 0 & + & 0 & 0 & 0 & + & 0 & 0 & H & + \\
\hline 9 & $\mathrm{~T}$ & I & $q$ & 70 & $\mathrm{R}$ & $\mathrm{H}$ & $H$ & $\mathrm{HH}$ & $H$ & W & $\mathrm{HH}$ & + & 0 & 0 & + & 0 & $H$ & 0 & 0 & 0 & 0 & & 0 \\
\hline 10 & $\mathrm{M}$ & $\mathrm{N}$ & $\hat{\delta}$ & 61 & $\mathrm{~L}$ & $H$ & $H$ & $\mathrm{HH}$ & $\mathrm{HH}$ & H & $H$ & $H$ & 0 & 0 & $H$ & $\mathrm{HH}$ & + & Ht & $H$ & 0 & 0 & H & + \\
\hline 11 & $\mathrm{M}$ & & 8 & 58 & $\mathrm{R}$ & $\mathrm{Ht}$ & 0 & mt & $H$ & m & $H$ & $H$ & 0 & 0 & $H$ & H & H & $\mathrm{HH}$ & $t$ & 0 & 0 & & 0 \\
\hline 12 & $\mathrm{C}$ & & $\hat{z}$ & 7 & L & H & $H$ & $H$ & $H$ & $H$ & $H$ & $H$ & 0 & 0 & $H$ & $\mathrm{HH}$ & $H$ & $\mathrm{HH}$ & $H$ & 0 & + & & 0 \\
\hline 13 & $\mathrm{~K}$ & $\mathrm{Y}$ & 9 & 59 & $\mathrm{~L}$ & $\mathrm{Ht}$ & 0 & $\mathrm{HH}$ & 0 & H & $\mathrm{HH}$ & + & 0 & 0 & $\mathrm{HH}$ & $H$ & $\mathrm{Ht}$ & + & $\mathrm{H}$ & 0 & 0 & + & + \\
\hline 14 & $z$ & $E$ & $\delta$ & 70 & L & $\mathrm{Ht}$ & $H$ & $\mathrm{HH}$ & $H$ & $\mathrm{HH}$ & $\mathrm{H}$ & 0 & 0 & 0 & $H$ & + & + & $H$ & $\mathrm{H}$ & 0 & 0 & & 0 \\
\hline 15 & $\mathrm{M}$ & I & q & 46 & $\mathrm{R}$ & $H$ & $\mathrm{HH}$ & $\mathrm{HH}$ & $H$ & $\mathrm{HH}$ & $\mathrm{HH}$ & $H$ & $\mathrm{HH}$ & 0 & $H$ & $H$ & 0 & + & + & 0 & + & tt & + \\
\hline 16 & $\mathrm{E}$ & $\mathrm{O}$ & $\hat{o}$ & 55 & $\mathrm{~L}$ & 0 & 0 & $H$ & $H$ & $H$ & $H$ & 0 & 0 & 0 & 0 & 0 & 0 & 0 & 0 & 0 & 0 & H & 0 \\
\hline 17 & $\mathrm{TH}$ & $\mathrm{Ko}$ & $q$ & 43 & $\mathrm{~L}$ & $t$ & 0 & $H$ & 0 & $H$ & W & $H$ & 0 & 0 & $H$ & $H$ & H & + & $H$ & 0 & 0 & & 0 \\
\hline 18 & & $\mathrm{O}$ & $q$ & 63 & L & 冊 & H & $H$ & $H$ & $\mathrm{HH}$ & $\mathrm{H}$ & + & 0 & 0 & $\mathrm{H}$ & $\mathrm{HH}$ & W & $H$ & \# & 0 & 0 & + & + \\
\hline 19 & $\mathbf{S}$ & $\mathrm{H}$ & ๆ & 64 & $\mathrm{R}$ & $H$ & $H$ & $H$ & $H$ & $\mathrm{H}$ & WH & + & 0 & 0 & $H$ & $H$ & + & $H$ & + & 0 & 0 & $H$ & + \\
\hline 20 & $\mathbf{S}$ & $\mathrm{M}$ & $\hat{b}$ & 41 & $\mathrm{~L}$ & $H$ & $\mathrm{H}$ & $\mathrm{H}$ & H & $\mathrm{H}$ & $\mathrm{HH}$ & $H$ & 0 & 0 & $\mathrm{HH}$ & $\mathrm{Ht}$ & $H$ & $\frac{1}{t}$ & 0 & 0 & 0 & $T$ & 0 \\
\hline 21 & & & $\hat{o}$ & 28 & $\mathrm{~L}$ & $H$ & $\mathrm{H}$ & $H$ & $H$ & H & $\mathrm{H}$ & + & 0 & 0 & + & 0 & 0 & 0 & 0 & 0 & 0 & $\mathrm{HH}$ & 0 \\
\hline 22 & $\mathrm{TH}$ & $\mathrm{Ka}$ & $\delta$ & 28 & 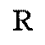 & $H$ & $\mathrm{HH}$ & $\mathrm{HH}$ & $\mathrm{HH}$ & $H$ & $\mathrm{H}$ & + & 0 & 0 & $H$ & $H$ & 0 & $\mathrm{HH}$ & $\mathrm{HH}$ & 0 & 0 & $H$ & + \\
\hline 23 & $\mathrm{~S}$ & $\mathrm{~S}$ & $\hat{\partial}$ & 79 & $\mathrm{~L}$ & $H$ & $H$ & $\mathrm{HH}$ & $H$ & \# & $H$ & + & 0 & 0 & $H$ & $H$ & + & $\mathrm{HH}$ & $H$ & 0 & 0 & 0 & 0 \\
\hline 24 & $\mathrm{~K}$ & $\mathrm{~A}$ & $q$ & 55 & $\mathrm{~L}$ & $H$ & $H$ & $\mathrm{HH}$ & $H$ & $H$ & $H$ & $t$ & 0 & 0 & $\mathrm{Ht}$ & $\mathrm{HH}$ & + & $\mathrm{HH}$ & $H$ & 0 & 0 & + & 0 \\
\hline 25 & I & $\mathrm{M}$ & $\hat{b}$ & 59 & $\mathrm{~L}$ & 0 & $\mathrm{HH}$ & $H$ & $H$ & $H$ & $\mathrm{HH}$ & 0 & 0 & 10 & + & + & + & 0 & 0 & 0 & 0 & $t$ & 0 \\
\hline 26 & $\mathrm{TH}$ & $\mathrm{Ki}$ & $\delta$ & 53 & $\mathbf{R}$ & $H$ & H & $H$ & $H$ & H & H & 0 & 0 & 0 & $t$ & + & 0 & + & + & 0 & 0 & $H$ & 0 \\
\hline 27 & $\mathrm{~K}$ & $\mathrm{~S}$ & $\delta$ & 57 & $\mathrm{R}$ & $\mathrm{HI}$ & 0 & $\mathrm{Ht}$ & $\mathrm{HH}$ & $\mathrm{HH}$ & $\mathrm{HH}$ & + & 0 & 0 & $\mathrm{HH}$ & $\mathrm{Ht}$ & $\mathrm{H}$ & $\mathrm{HH}$ & \pm & 0 & 0 & $H$ & 0 \\
\hline 28 & $\mathrm{Y}$ & W & $q$ & 48 & - & $H$ & 0 & $H$ & $\mathrm{HH}$ & W & $\mathrm{HH}$ & 0 & 0 & 0 & $H$ & + & + & 0 & + & 0 & 0 & H & 0 \\
\hline 29 & & $N$ & q & 67 & $\mathrm{~K}$ & \# & $H$ & $\mathrm{HH}$ & $H$ & $H$ & H & $H$ & 0 & 10 & $H$ & $H$ & $H$ & $\mathrm{HH}$ & $H$ & 0 & 0 & m & + \\
\hline 30 & & $\mathbf{M}$ & $\delta$ & 37 & $\mathrm{~L}$ & HH & 0 & $H$ & $H$ & $H$ & H & + & 0 & 10 & + & + & $H$ & 0 & 0 & 0 & 0 & $t$ & + \\
\hline
\end{tabular}

大多数の例が不規則性を示す。

b）上顎洞上壁 (表 12)

正常例 4 例全てが $\mathrm{X}$ 楾上軽度乃至中等度厚化を，骨 侵遙例 6 例全てが軽度 乃至高度厚化を示し，骨欠損例 20 例中 10 例が断絶・消失を示すか，他の 10 例は中等 度 乃至高度厚化を示す 両所見の一致率は 16/30であ る。な挔，表中太染の中が両所見の一致を示す（以下 の表むこれに同し.) c) 上顎洞下壁 (表 14)

正常例 10 例中 4.例が $\mathrm{X}$ 線上も正常所見を示寸が，6 例は軽度か中等度厚化を示しており，粘膜侵融例 1 例が 中等度厚化を，骨侵零例 5 例全てが軽度乃至中等度厚化 を示し，骨欠損例 14 例中 10 例は断絶・消失を示すが， 4 例は軽度 乃至高度厚化を示す一教率は20/30であ る. 
表 2 後頭 前頭 撮 影 所 見

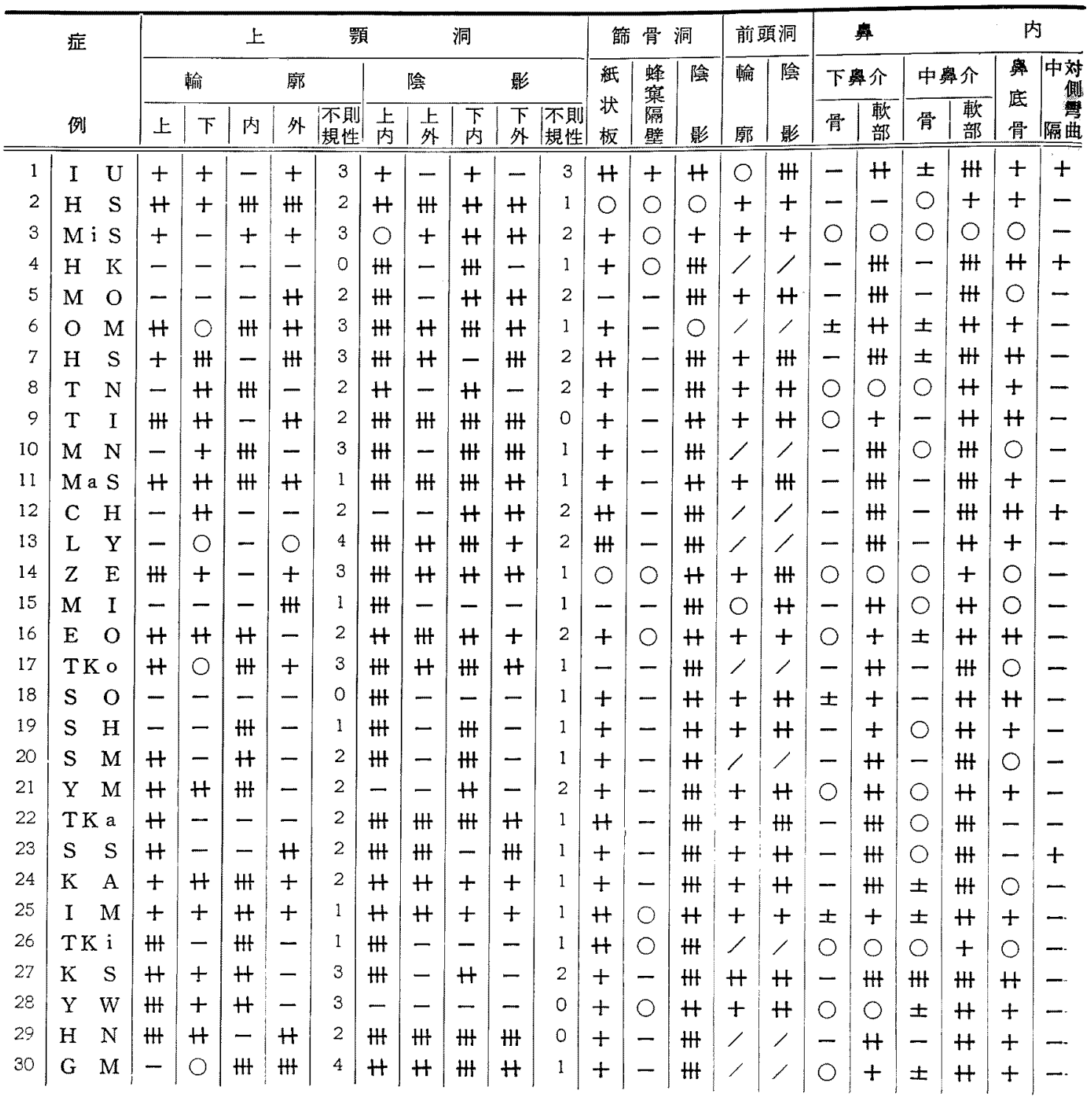

\section{d）上顎洞内壁 (表 16)}

正常例 1 例が軽度厚化を，骨侵薢例 5 例全てが中等度 乃至高度厚化を示し，骨欠損例 24 例中 13 例が断絶・消 失を示すが，11 例は中等度 乃至高度愿化を示す一致 率は18/30である。

e）上靧洞外壁 (表 18)

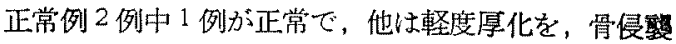
例 9 例全てが軽度乃至高度厚化を示し，骨欠損例 19 例
中 13 例は断絶・消失を示すが，6例は俥度乃至高度厚 化を示す 一致率は23/30で，他壁より高率である。 又, 各壁陰影の不規則性は30 例中 28 例で認められる。

f）紙状板と笠骨䗋黛との関係（表 24）

節骨蜂杲正常例 7 例中 2 例が $\mathrm{X}$ 線上紙状板正常で， 5 例は軽度 万至高度厚化を, 軽度侵翼例 13 例全てが軽: 度乃至高度厚化を示し，高度侵篦例 10 例中 7 例が軽度 乃至高度厚化を示し，3例は断絶・消失を示す，一致率 
表 3 後頭䫄撮影 所見

\begin{tabular}{|c|c|c|c|c|c|c|c|c|c|c|c|c|c|c|c|c|}
\hline & \multirow{3}{*}{$\begin{array}{l}\text { 症 } \\
\text { 例 }\end{array}$} & \multicolumn{5}{|c|}{5} & \multicolumn{2}{|c|}{ 䅡 } & \multicolumn{3}{|c|}{ 洞 } & & \multirow{3}{*}{$\begin{array}{l}\text { 㭔 } \\
\text { 状 } \\
\text { 板 }\end{array}$} & \multicolumn{2}{|c|}{ 前頭洞 } & \multirow{3}{*}{$\begin{array}{l}\text { 臮 } \\
\text { 内 } \\
\text { 陰 } \\
\text { 影 }\end{array}$} \\
\hline & & \multicolumn{2}{|r|}{ 輸 } & \multicolumn{3}{|c|}{ 廓 } & \multicolumn{2}{|c|}{ 陵 } & \multicolumn{3}{|c|}{ 影 } & \multirow{2}{*}{ 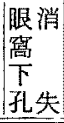 } & & 翰 & & \\
\hline & & 上 & 下 & 内 & 外 & $\begin{array}{l}\text { 不則 } \\
\text { 規性 }\end{array}$ & 上 & 卡 & $\begin{array}{c}\text { 下 } \\
\text { 内 }\end{array}$ & $\begin{array}{l}\mathrm{T} \\
\text { 外 }\end{array}$ & $\begin{array}{l}\text { 不則 } \\
\text { 規性 }\end{array}$ & & & 遊 & 影 & \\
\hline 1 & I $\quad \mathrm{U}$ & $H$ & 柬牙 & - & + & 3 & + & $H$ & $H$ & + & 1 & $H$ & $H$ & $H$ & $H$ & 4 \\
\hline 2 & $\mathrm{H} \quad \mathrm{S}$ & H & 嘖牙 & $\mathrm{HH}$ & $H$ & 0 & $\mathrm{HH}$ & $H$ & $H$ & $H$ & 1 & + & 0 & 8 & + & \\
\hline 3 & $\mathrm{Mi} \mathrm{S}$ & + & 菌牙 & + & + & 0 & 0 & $H$ & 0 & $H$ & 2 & 0 & + & 0 & + & \\
\hline 4 & $\mathrm{H} \quad \mathrm{K}$ & - & - & - & - & 0 & $H$ & $H$ & $\mathrm{Ht}$ & $H$ & 1 & + & + & $\gamma$ & $\gamma$ & t \\
\hline 5 & $\mathrm{M} \quad \mathrm{O}$ & - & 㥰牙 & - & $H$ & 2 & $H$ & $H$ & $\mathrm{Ht}$ & $H$ & 0 & H & - & $t$ & $H$ & H \\
\hline 6 & $\mathrm{O} \quad \mathrm{M}$ & - & 0 & - & $H$ & 4 & $H$ & $H$ & H & $H$ & 1 & \pm & + & $t$ & $H$ & H \\
\hline 7 & $\mathrm{H} \quad \mathrm{S}$ & + & $\mathrm{HH}$ & 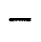 & $H$ & 3 & $\mathrm{Ht}$ & $H$ & $H$ & $\mathrm{Ht}$ & 1 & 0 & 11 & 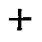 & $m$ & $\mathrm{HI}$ \\
\hline 8 & $\mathrm{~T} \quad \mathrm{~N}$ & - & $H$ & $\mathrm{Ht}$ & - & 2 & $H$ & - & $H$ & $H$ & 2 & + & 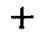 & + & $H$ & $H$ \\
\hline 9 & $T$ & H & $H$ & - & $H$ & 2 & H & \# & $H$ & $H$ & 1 & \pm & + & + & + & $H$ \\
\hline 10 & $\mathrm{MN}$ & - & 宷牙 & - & - & 0 & $H$ & $\mathrm{HH}$ & $\mathrm{H}$ & $H$ & 1 & $t$ & - & $t$ & $t$ & $\mathrm{Ht}$ \\
\hline 11 & $\mathrm{MaS}$ & $H$ & 嶓牙 & - & $H$ & 2 & $H$ & $H$ & $H$ & $H$ & 1 & $H$ & $t$ & $H$ & $H$ & $H$ \\
\hline 12 & C $\mathrm{H}$ & - & $H$ & - & - & 2 & H & HH & $H$ & H & 0 & \pm & + & $\gamma$ & 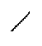 & $H$ \\
\hline 13 & K Y & $H$ & 0 & - & + & 4 & $H$ & $H$ & $\mathrm{Ht}$ & $\pi$ & 1 & s & 1 & 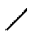 & 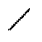 & m \\
\hline 14 & $E$ & - & 歯牙 & - & - & 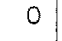 & $H$ & $H$ & $H$ & $H$ & 1 & + & 0 & $T$ & + & 0 \\
\hline 15 & M I & - & - & - & $\mathrm{HH}$ & 1 & $H$ & $H$ & $\mathrm{HH}$ & $H$ & 4 & $H$ & - & 0 & 0 & $H$ \\
\hline 16 & E O & $H$ & $H$ & $\mathrm{Ht}$ & - & 1 & $H t$ & $H$ & H & $H$ & 1 & \pm & + & + & $H$ & + \\
\hline 17 & T K o & $H$ & 0 & $H$ & 0 & 2 & $\mathrm{Ht}$ & $H$ & $H$ & $H$ & 1 & 0 & 0 & I & $Y$ & $H$ \\
\hline 18 & $\mathrm{~S} O$ & - & - & - & $\mathrm{H}$ & 1 & Ht & $t$ & $H$ & - & 2 & $H$ & $H$ & + & $H$ & + \\
\hline 19 & $\mathrm{H}$ & - & - & $H$ & - & 1 & H & H & $\mathrm{Ht}$ & - & 1 & $T$ & I & 1 & $\pi$ & $T$ \\
\hline 20 & S M & $H$ & - & - & - & 2 & $H$ & $\mathrm{HH}$ & $\mathrm{HH}$ & $H$ & t & \pm & - & 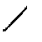 & $Y$ & $H$ \\
\hline 21 & Y $\quad \mathrm{M}$ & $H$ & 料牙 & $H$ & - & 2 & $H$ & $\mathrm{Ht}$ & H & $H$ & 1 & $t$ & $t$ & $t$ & $H$ & $H$ \\
\hline 22 & T K a & - & 歯牙 & - & - & 0 & $\mathrm{H}$ & $\mathrm{HH}$ & $\mathrm{HH}$ & $\mathrm{HH}$ & 0 & $H$ & $t+$ & 0 & $\mathrm{HH}$ & $H$ \\
\hline 23 & $S \quad S$ & - & $H$ & - & $H$ & 2 & $H$ & $H$ & $H$ & $H$ & 1 & + & $H$ & + & $H$ & $H$ \\
\hline 24 & K A & H & $H$ & - & + & 3 & $H$ & $\mathrm{HH}$ & $\mathrm{HH}$ & H & t & \pm & $t$ & $t$ & 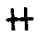 & $H$ \\
\hline 25 & I $\mathrm{M}$ & + & - & + & + & 3 & $H$ & $H$ & $\mathrm{HH}$ & H & 1 & 0 & $t$ & $t$ & + & + \\
\hline 26 & T K i & $H$ & - & - & - & 1 & $H$ & $\mathrm{Ht}$ & $H$ & $H$ & 1 & \pm & $H$ & $\nearrow$ & I & 0 \\
\hline 27 & & - & 歯牙 & $H$ & - & 2 & + & $\mathrm{Ht}$ & H & $H$ & 2 & \pm & + & 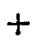 & + & $H$ \\
\hline 28 & $\mathrm{Y} \quad \mathrm{W}$ & - & + & $H$ & - & 3. & $\mathrm{HH}$ & + & $\mathrm{HH}$ & - & 3 & + & + & t & + & $t$ \\
\hline 29 & $\mathrm{H} \quad \mathrm{N}$ & - & + & - & - & 3 & $H$ & $H$ & $H$ & $H$ & 0 & $H$ & $t$ & ノ & $\gamma$ & $H$ \\
\hline 30 & G $\quad M$ & - & 造牙 & $\mathrm{HH}$ & $H$ & 1 & $H$ & $\mathrm{HH}$ & H & $H$ & 1 & + & + & 1 & I & $H$ \\
\hline
\end{tabular}

は25/30である。

g）篩骨蜂穼とその隔壁との関係（表 25）

節骨蜂窂正常例 7 例全てが $\mathrm{X}$ 線上隔壁正常で, 軽度 侵期例 13 例中 12 例は断絶・消失を示すが，1例は正常 で，高度侵繁例 10 例中 1 例加愿化を示し，9例は断絶・ 消失を示す，一致率は29/30 の高率である。なお，解骨 洞陰影は大多数例で增強が見られる。 h) 前 頭 洞

前頭洞への侵臵は全例で諗められないが，X線上輸澵 は20 例中 17 例で軽度，1 例で中等度唇化を示し，陰影 は全例で增強し，しかも軽度增強はその中ろ例に過ぎな W.

i）下翼介骨 (表 27)

正常例 5 例全てが $\mathrm{X}$ 線上も正常で，軟部侵䫓例 5 例 
表 4 軸位振影所見

\begin{tabular}{|c|c|c|c|c|c|c|c|}
\hline \multirow{2}{*}{\multicolumn{2}{|c|}{$\begin{array}{l}\text { 症 } \\
\text { 例 } \\
\end{array}$}} & \multirow{2}{*}{$\begin{array}{l}\text { 上後 } \\
\text { 敫碚 }\end{array}$} & \multicolumn{2}{|c|}{ 蚌 形 洞 } & \multicolumn{2}{|c|}{ 翼状突起 } & \multirow{2}{*}{$\begin{array}{l}\text { 煩 } \\
\text { 骨 } \\
\text { 隐 } \\
\text { 影 } \\
\end{array}$} \\
\hline & & & $\begin{array}{l}\text { 鐱 } \\
\text { 郸 }\end{array}$ & 峌 & 形 & 陰 & \\
\hline 1 & $\mathbf{I} \mathbf{U}$ & $H$ & 0 & + & 0 & + & 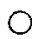 \\
\hline 2 & $\mathrm{H} \quad \mathrm{S}$ & H & + & + & 0 & $\pi$ & $H$ \\
\hline 3 & $M$ i $S$ & $m$ & + & $H$ & 0 & $H$ & U \\
\hline 4 & $\begin{array}{ll}\mathrm{H} & \mathrm{K}\end{array}$ & - & + & $H$ & - & - & 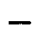 \\
\hline 5 & $\begin{array}{ll}M & O\end{array}$ & $H$ & H & $\pi$ & 0 & H & m \\
\hline 6 & $\begin{array}{ll}O & M\end{array}$ & $\pi$ & H & $H$ & 0 & H & \# \\
\hline 7 & $\mathrm{H} \quad \mathrm{S}$ & - & H & m & 0 & $\pi$ & H \\
\hline 8 & $\begin{array}{ll}\mathrm{T} & \mathrm{N}\end{array}$ & 下顎骨 & H & H & 0 & HI & - \\
\hline 9 & $\mathrm{~T} I$ & $H$ & 0 & + & 0 & $t$ & H \\
\hline 10 & $\begin{array}{ll}M & \mathrm{~N}\end{array}$ & 下顎骨 & $H$ & H & 0 & $H$ & 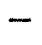 \\
\hline 11 & Ma S & \# & $H$ & H & 0 & $\mathrm{H}$ & H \\
\hline 12 & $\mathrm{C} \quad \mathrm{H}$ & $T$ & $H$ & $H$ & - & $H$ & 册 \\
\hline 13 & $\mathrm{~K} \quad \mathrm{Y}$ & 下顎骨 & $H$ & $\mathrm{H}$ & 0 & $t$ & H \\
\hline 14 & $Z E$ & H & + & + & 0 & H & + \\
\hline 15 & M I & - & - & H & - & - & H \\
\hline 16 & E O & $\mathrm{HH}$ & + & $H$ & 0 & $H$ & $H$ \\
\hline 17 & TKo & $\mathrm{HH}$ & H & H & 0 & H & + \\
\hline 18 & $S O$ & $H$ & + & $H$ & 0 & + & $H$ \\
\hline 19 & $\mathrm{~S} \quad \mathrm{H}$ & - & + & $H$ & 0 & $H$ & $H$ \\
\hline 20 & $\mathrm{~S} \quad \mathrm{M}$ & - & $H$ & $\mathrm{~m}$ & 0 & $H$ & + \\
\hline 21 & $\mathrm{Y} \quad \mathrm{M}$ & - & $H$ & $H$ & 0 & + & - \\
\hline 22 & T K a & 下顎骨 & $H$ & $H$ & 0 & $H$ & - \\
\hline 23 & $\mathbf{S} \mathrm{S}$ & + & $H$ & H & 0 & + & + \\
\hline 24 & $\mathrm{~K} A$ & + & + & . & 0 & + & + \\
\hline 25 & I $M$ & H & + & $H$ & 0 & $H$ & $H$ \\
\hline 26 & $\mathrm{TK} \mathrm{i}$ & 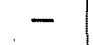 & $H$ & H & 0 & H & 世 \\
\hline 27 & $\mathrm{~K} S$ & H & $H$ & $H$ & 0 & H & $H$ \\
\hline 28 & $\mathrm{Y} \quad \mathrm{W}$ & - & 0 & + & 0 & $H$ & - \\
\hline 29 & $\mathrm{H} \quad \mathrm{N}$ & - & $H$ & m & 0 & + & $H$ \\
\hline 30 & G $\quad \mathrm{M}$ & $H$ & $H$ & $H$ & 0 & $H$ & 11 \\
\hline
\end{tabular}

中4 例が正常で，1 例は骨下端消失を，骨侵盤例 12 例 全てが骨消失を示し，骨崩壊例 8 例中 6 例は骨消失を示 すが，2 例は骨下端消失を示す一致率は 27/30であ る.

\section{j）中奥介骨}

正常例 7 例中 6 例が $X$ 線上も正常で，1 例佉骨下端 消失を，軟部侵蟹例 10 例中 5 例が正常で，他の 5 例は 骨下端消失を，骨侵襲例 7 例中 2 例が骨下端消失を，5 例は骨消失を示し，骨崩壊例 6 例全てが骨消失を示す。 一致率は $24 / 30$ である。
表 5 レーゼ氏法撮影所見

\begin{tabular}{|c|c|c|c|c|c|c|c|c|c|c|c|c|c|c|}
\hline & 症 & & & & 上 & & & & & 桜 & & & & \\
\hline & & & & 錀 & & 暆 & & 陰 & 舎 & & 影 & & 輪 & 陰 \\
\hline & 例 & & 上 & 下 & $\begin{array}{l}\text { 梨 } \\
\text { 桨 } \\
\text { 孔 } \\
\end{array}$ & 往 & $\begin{array}{l}\text { 不 } \\
\text { 規 } \\
\text { 邲 } \\
\text { 性 }\end{array}$ & $\begin{array}{c} \\
1 \\
\text { 前 } \\
\end{array}$ & 後 & 前 & 後 & $\begin{array}{l}\text { 不 } \\
\text { 替 } \\
\text { 則 } \\
\text { 性 } \\
\end{array}$ & 窝离 & 影 \\
\hline 8 & & & - & + & $H$ & -1 & 2 & $H$ & $\mathrm{HH}$ & $H$ & W & 1 & 0 & 0 \\
\hline 9 & & I & $H$ & $H$ & $H$ & $t+$ & 0 & $H$ & $\mathrm{HH}$ & $H$ & $\mathrm{HH}$ & 1 & 0 & 10 \\
\hline 10 & $\mathbf{M}$ & $N$ & - & $H$ & - & & 2 & $H$ & $\mathrm{HH}$ & $H$ & $\mathrm{HH}$ & 1 & $H$ & + \\
\hline 11 & $\mathrm{M}$ & $\mathrm{S}$ & - & + & $\mathrm{HH}$ & TT & 3 & + & $H$ & $\mathrm{HH}$ & $\mathrm{HI}$ & 2 & 0 & 10 \\
\hline 12 & & $\mathrm{H}$ & - & $H$ & - & 丹 & 2 & $H$ & $\mathrm{H}$ & $H$ & $\mathrm{H}$ & 1 & 0 & + \\
\hline 13 & $\mathrm{~K}$ & $\mathrm{Y}$ & - & $H$ & - & - & 2 & tH & $\mathrm{HH}$ & - & $H$ & 2 & + & + \\
\hline 1 & $Z$ & $\mathrm{E}$ & HH & Ht & $\mathrm{HH}$ & & 2 & $H$ & $\mathrm{tt}$ & $H$ & $\mathrm{Ht}$ & 1 & 0 & 10 \\
\hline 15 & $\mathbf{M}$ & 1 & $1-$ & - & $H$ & & 2 & HI & - & $H$ & - & 2 & $H$ & $H$ \\
\hline 16 & & $\mathrm{O}$ & + & $H$ & + & 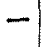 & 3 & $H$ & - & $H$ & $\mathrm{HH}$ & 2 & + & + \\
\hline 17 & $\mathrm{TI}$ & 0 & $H$ & $H$ & + & - & 3 & $H$ & $H$ & $H$ & $H$ & 1 & $H$ & + \\
\hline 18 & S & $\mathrm{O}$ & - & - & - & - & 0 & $H$ & $\mathrm{HH}$ & $\mathrm{H}$ & $\mathrm{Ht}$ & 1 & + & $H$ \\
\hline 19 & 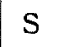 & 11 & I & $H$ & $H$ & & 2 & + & + & $\mathrm{Ht}$ & $\mathrm{H}$ & 2 & 0 & + \\
\hline 20 & $\mathrm{~S}$ & $\mathrm{M}$ & $H$ & - & - & & 1 & $\mathrm{HI}$ & $\mathrm{HH}$ & - & - & 1 & 10 & 10 \\
\hline 21. & & $\mathrm{M}$ & $H$ & - & $H$ & & 2 & \pm & $H$ & $H$ & $\mathrm{HH}$ & 2 & + & + \\
\hline 22 & $T H$ & $\mathrm{a}$ & - & - & - & - & 0 & +1 & $\mathrm{H}$ & H & $\mathrm{Ht}$ & ${ }^{2}$ & $H$ & $H$ \\
\hline 23 & $\mathrm{~S}$ & & - & - & - & & 1 & $H$ & $\mathrm{HH}$ & $H$ & $\mathrm{HH}$ & 0 & 0 & + \\
\hline 24 & & $\mathrm{~A}^{\prime}$ & $H$ & $H$ & - & & 2 & $\mathrm{HH}$ & $\mathrm{HH}$ & $\mathrm{HH}$ & $\mathrm{H}$ & I & 0 & + \\
\hline 25 & & & $H$ & - & 0 & & 4 & $H$ & $H$ & $H$ & $\mathrm{HH}$ & 1 & 0 & 0 \\
\hline 26 & $\mathrm{TH}$ & & $H$ & - & $\mathrm{HH}$ & - & 2 & H & $\mathrm{H}$ & $\mathrm{HH}$ & $\mathrm{HH}$ & 0 & 0 & 0 \\
\hline 0 & & $\mathrm{~S}$ & $H^{\prime}$ & + & - & & 3 & H & $\mathrm{Ht}$ & $\mathrm{Ht}$ & $H$ & 1 & $H$ & + \\
\hline 28 & & W & - & + & $H$ & & 3 & $H$ & $\mathrm{HH}$ & 0 & $\mathrm{Ht}$ & 3 & 0 & 10 \\
\hline 29 & & $\mathbf{N}$ & - & $H$ & - & & 2 & $\mathrm{HH}$ & $\mathrm{H}$ & $H$ & $H$ & 1 & + & $H$ \\
\hline 30 & & $\mathrm{M}$ & $H$ & + & $H$ & & 3 & $H$ & $H$ & $\mathrm{HH}$ & $\mathrm{HH}$ & 1 & $0 \mid$ & $t$ \\
\hline
\end{tabular}

k）鼻 底 骨 (表 29)

正常例 7 例中 2 例が $\mathrm{X}$ 線上む正常であるが，4 例は 軽度乃至高度厚化を，軟部侵垶例 8 例中 6 例が軽度乃至 高度厚化を示士が：2 例は正常で，骨侵裂例 7 例中 4 例 が軽度乃至高度厚化を示すが，3 例は正常で，骨欠損例 9 例中 2 例が断絶・消失を示寸のみで， 3 例は正常で， 4 例は軽度乃至高度厚化を示す一致率は 14/30 と低率 である。

1)鼻中雬

鼻中隔の対側への禁典は30 例中 4 例に見られ，いず れも上顎洞内壁への尰湯の侵蔓の著しい例である。

2）後頭碩撮影（表 3 )

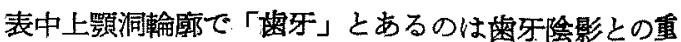
置による下壁の読影不能を示す，眼简下孔消失の項で快 
表 6 前 頭 断 層 撮影所見

\begin{tabular}{|c|c|c|c|c|c|c|c|c|c|c|c|c|c|c|c|c|c|c|c|c|c|c|c|c|c|c|c|c|}
\hline \multirow{3}{*}{\multicolumn{2}{|c|}{$\begin{array}{l}\text { 症 } \\
\text { 例 }\end{array}$}} & \multirow{3}{*}{$\begin{array}{l}\text { 断 } \\
\text { 图 } \\
\text { 面 }\end{array}$} & \multicolumn{5}{|c|}{ 上 } & \multicolumn{2}{|c|}{ 顎 } & & \multicolumn{3}{|c|}{ 洞 } & \multicolumn{3}{|c|}{ 篩＼cjkstart骨＼cjkstart洞 } & \multicolumn{2}{|c|}{ 蝶形洞 } & \multicolumn{3}{|c|}{ 率 } & & \multicolumn{3}{|c|}{ 内 } & \multicolumn{2}{|c|}{ 翼状笑起 } & \multirow{3}{*}{\begin{tabular}{|l} 
蝢 \\
骨 \\
陰 \\
影
\end{tabular}} \\
\hline & & & & 輪 & & & & & 陰 & & & 影 & & & & & & & 下悬 & 介 & 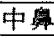 & & & 悬中 & & & & \\
\hline & & & 上 & 下 & 内 & 外 & 替 & 内 & 93 & & 内 & 外 & 嫢 & $\begin{array}{l}\text { 枤 } \\
\text { 板 }\end{array}$ & $\begin{array}{l}\text { 蜂 } \\
\text { 隔 } \\
\text { 壁 }\end{array}$ & 影 & 廓 & 影 & 骨 & 軟 & 骨 & 部 | & $\begin{array}{c}\text { 底 } \\
\text { 骨 }\end{array}$ & 骨 & $\begin{array}{l}\text { 対 } \\
\text { 側 } \\
\text { 栔 } \\
\text { 典 }\end{array}$ & 態 & & \\
\hline 1 & $\mathrm{U}$ & $\begin{array}{l}1 \\
2 \\
3 \\
4 \\
\end{array}$ & $\left|\begin{array}{l}+ \\
+ \\
0 \\
y\end{array}\right|$ & $\begin{array}{l}1 \\
+ \\
+\end{array}$ & $\frac{H}{y}$ & $\begin{array}{l}+ \\
+ \\
+\end{array}$ & 4 & $\begin{array}{l}\text { H } \\
\text { H } \\
H\end{array}$ & \begin{tabular}{l|l}
+ \\
+ \\
+ \\
+
\end{tabular} & $\begin{array}{l}+ \\
+ \\
+1\end{array}$ & \begin{tabular}{|l}
+4 \\
+4 \\
$H$
\end{tabular} & \begin{tabular}{l|}
$+\#$ \\
+ \\
+ \\
\end{tabular} & 2 & $t$ & $\bar{z}$ & $\begin{array}{l}\text { H } \\
\text { H } \\
\text { H }\end{array}$ & $\frac{1}{6}$ & $\frac{1}{1}$ & $\frac{1}{1}$ & $\begin{array}{l}+ \\
+ \\
+ \\
\text { H }\end{array}$ & \begin{tabular}{|l|} 
\pm \\
\pm \\
\pm \\
\end{tabular} & 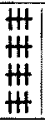 & $\begin{array}{l} \\
0 \\
+ \\
+\end{array}$ & \pm & $\begin{array}{l}+ \\
+ \\
+ \\
+\end{array}$ & & $\frac{1}{1}$ & , \\
\hline 2 & $\mathrm{~S}$ & $\begin{array}{l}1 \\
2 \\
3 \\
4 \\
\end{array}$ & $\mid \begin{array}{l}\# \\
-1\end{array}$ & $\mid \begin{array}{l}1 \\
+ \\
+ \\
\end{array}$ & 無 & 曲 & 3 & H & $\begin{array}{l}+4 \\
+ \\
+\end{array}$ & + & 开 & $\begin{array}{l}+ \\
+ \\
H \\
\end{array}$ & 2 & $\begin{array}{l}0 \\
0 \\
0\end{array}$ & $\begin{array}{l}0 \\
0 \\
0\end{array}$ & $\begin{array}{l}0 \\
+ \\
0\end{array}$ & $\frac{1}{6}$ & $\frac{1}{4}$ & 17 & $\begin{array}{l}+ \\
+ \\
+ \\
+\end{array}$ & $\left|\begin{array}{l}9 \\
0 \\
0 \\
1\end{array}\right|$ & $\begin{array}{l}+ \\
+ \\
+ \\
+\end{array}$ & $\begin{array}{l}0 \\
0 \\
+ \\
+\end{array} \mid$ & $\begin{array}{l}0 \\
0 \\
0\end{array}$ & $\begin{array}{l}0 \\
0 \\
0 \\
0\end{array}$ & & & $\begin{array}{l}+ \\
+ \\
+\end{array}$ \\
\hline 3 & $\stackrel{\mathrm{M}}{\mathrm{i}}$ & $\begin{array}{l}1 \\
2 \\
3 \\
4 \\
\end{array}$ & $\left|\begin{array}{l}0 \\
H \\
H\end{array}\right|$ & 莽 & $\begin{array}{l}+ \\
+ \\
+\end{array}$ & $\begin{array}{l}+ \\
+ \\
+ \\
H\end{array}$ & 3 & $\begin{array}{l}+ \\
+ \\
+\end{array}$ & $t+$ & $\begin{array}{l}+ \\
+ \\
+ \\
+\end{array}$ & $\begin{array}{l}\text { H } \\
+ \\
+ \\
+1\end{array}$ & \begin{tabular}{l|} 
册 \\
+ \\
+ \\
\end{tabular} & 2 & 0 & $\begin{array}{l}0 \\
0 \\
0\end{array}$ & $\begin{array}{l}+ \\
+ \\
+\end{array}$ & $\frac{1}{6}$ & $\frac{1}{1}$ & $\mid \begin{array}{l}0 \\
0 \\
0\end{array}$ & $\begin{array}{l}9 \\
0 \\
0 \\
0\end{array}$ & $\left|\begin{array}{l}9 \\
0 \\
0 \\
1\end{array}\right|$ & $\begin{array}{l}\bigcirc \\
\bigcirc \\
\bigcirc \\
\bigcirc\end{array}$ & $\left|\begin{array}{l}0 \\
0 \\
+ \\
\pm\end{array}\right|$ & 0 & $\begin{array}{l}0 \\
0 \\
0 \\
0\end{array}$ & $1 \frac{1}{6}$ & & 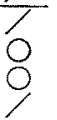 \\
\hline 4 & & $\begin{array}{l}1 \\
2\end{array}$ & $\frac{H}{H}$ & $\frac{1}{-}$ & $\frac{\mathrm{H}}{\mathrm{H}}$ & $\bar{z}$ & 2 & $\begin{array}{l}H \\
H \\
H\end{array}$ & & $\overline{-1}$ & 曲 & $\bar{z}$ & 1 & 0 & $\bar{z}$ & 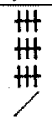 & $\frac{1}{1}$ & \% & $\frac{1}{2}$ & 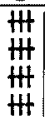 & $=$ & $\begin{array}{l}+ \\
+ \\
\text { W } \\
\mathrm{H}\end{array}$ & $\frac{H}{H}$ & $\begin{array}{l}0 \\
0 \\
0\end{array}$ & $\begin{array}{l}+ \\
+ \\
+ \\
+\end{array}$ & & & \\
\hline 5 & 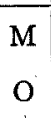 & $\begin{array}{l}1 \\
2 \\
3 \\
4\end{array}$ & $\bar{z}$ & $\frac{y}{H}$ & $\frac{1}{7}$ & H & 2 & H & : & $\overline{-}$ & 开 & $\begin{array}{l}+ \\
+ \\
\pm\end{array}$ & 3 & - & $\frac{0}{1}$ & 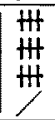 & $\begin{array}{l}1 \\
+\end{array}$ & $\frac{1}{\mathrm{H}}$ & 17 & 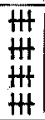 & $\begin{array}{l}z \\
z\end{array}$ & $\begin{array}{l}\mathrm{W} \\
\mathrm{W} \\
\mathrm{W} \\
\mathrm{W}\end{array}$ & $\begin{array}{l}+ \\
+ \\
+ \\
+\end{array}$ & 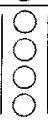 & $\begin{array}{l}+ \\
+ \\
+ \\
0\end{array}$ & & & \\
\hline 6 & $\mathrm{O}$ & $\begin{array}{l}1 \\
2 \\
3 \\
4\end{array}$ & $\mid \begin{array}{l}- \\
\end{array}$ & $\mid \begin{array}{l}+ \\
+ \\
+\end{array}$ & $\frac{W}{H}$ & $H$ & 3 & H & $\begin{array}{l}+ \\
+ \\
+ \\
t\end{array}$ & $\frac{E}{t}$ & 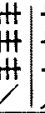 & $\begin{array}{l}H \\
H \\
H\end{array}$ & 2 & $\frac{ \pm}{0}$ & $\overline{0}$ & $\stackrel{+}{+}+$ & $\begin{array}{l}3 \\
+\end{array}$ & $\frac{1}{4}$ & $1=$ & $\begin{array}{l}H \\
\text { W } \\
H \\
H \\
H\end{array}$ & $\begin{array}{l}0 \\
8 \\
8\end{array}$ & $\begin{array}{l}H \\
H \\
H \\
H\end{array}$ & $\mid \begin{array}{l}+ \\
+ \\
H\end{array}$ & 18 & $\begin{array}{l}+ \\
+ \\
+ \\
0\end{array}$ & & & \\
\hline 7 & $\begin{array}{l}\mathrm{H} \\
\mathrm{s}\end{array}$ & $\begin{array}{l}1 \\
2 \\
3 \\
4 \\
\end{array}$ & $\mid \begin{array}{l}+ \\
+ \\
+ \\
t\end{array}$ & 冊 & $\overline{\bar{y}}$ & HI & 3 & H & & $\bar{z}$ & $\begin{array}{l}\text { H } \\
+ \\
+\end{array}$ & $\frac{H}{H}$ & 2 & $\begin{array}{l}H \\
H \\
H\end{array}$ & $\bar{z}$ & 朿 & $\frac{1}{6}$ & $\frac{1}{\mathrm{H}}$ & $\frac{1}{1}$ & 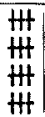 & $\mid \begin{array}{l}0 \\
0 \\
0\end{array}$ & $\begin{array}{c}\mathrm{m} \\
\mathrm{W} \\
\mathrm{W} \\
\mathrm{H}\end{array}$ & $\begin{array}{l}+ \\
+ \\
H \\
H\end{array}$ & 10 & $\begin{array}{l}0 \\
8 \\
8 \\
0\end{array}$ & 1 & $1 \%$ & \\
\hline 8 & & $\begin{array}{l}1 \\
2 \\
3 \\
4 \\
\end{array}$ & $\frac{1+}{2}$ & H & 莽 & $\bar{z}$ & 2 & H & & $\bar{z}$ & 再 & $\begin{array}{l}+ \\
+ \\
H\end{array}$ & 7 & 7 & $\bar{z}$ & $\begin{array}{l}H \\
H \\
H\end{array}$ & $\frac{1}{6}$ & $\begin{array}{l}\% \\
\mathrm{~m}\end{array}$ & 16 & $\begin{array}{l}0 \\
8 \\
0 \\
0\end{array}$ & $\mid \begin{array}{l}0 \\
0 \\
0 \\
y\end{array}$ & $\begin{array}{l}H \\
H \\
H \\
+\end{array}$ & $\begin{array}{l}+ \\
+ \\
+ \\
+\end{array}$ & 8 & $\begin{array}{l}0 \\
0 \\
0\end{array}$ & & $\frac{1}{H}$ & \\
\hline 9 & $\begin{array}{l}\text { T } \\
\text { I }\end{array}$ & $\begin{array}{l}1 \\
2 \\
3 \\
4 \\
\end{array}$ & H & H & $\frac{H}{H}$ & $\frac{1}{7}$ & 2 & $\begin{array}{r}\# \\
\# \\
\# \\
\#\end{array}$ & $4 t$ & 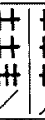 & 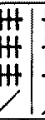 & $\begin{array}{l}\text { 朿 } \\
H \\
H\end{array}$ & 1 & \pm & $\bar{z}$ & 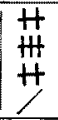 & $\begin{array}{l}1 \\
\mathrm{H}\end{array}$ & $\frac{1}{4}$ & $\begin{array}{l}1 \\
0 \\
0 \\
\end{array}$ & $\begin{array}{r}0 \\
+ \\
+ \\
+\end{array}$ & $\bar{z} \mid$ & \begin{tabular}{|l}
+ \\
+ \\
+ \\
$H$
\end{tabular} & $\left|\begin{array}{c}0 \\
+ \\
+ \\
+ \\
+\end{array}\right|$ & (1) & $\begin{array}{l}0 \\
0 \\
0 \\
0\end{array}$ & & & \\
\hline 10 & & $\begin{array}{l}1 \\
2 \\
3 \\
4\end{array}$ & $\bar{z}$ & 1 & 茾 & $\overline{\mathrm{H}}$ & 3 & H & 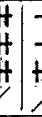 & $\bar{H} \mid$ & 开 & $\begin{array}{l}+ \\
H \\
H\end{array}$ & 2 & \pm & $\bar{z}$ & \begin{tabular}{|l} 
刺 \\
W \\
\end{tabular} & $\frac{1}{1}$ & $\frac{1}{\mathrm{H}}$ & $\frac{1}{7}$ & $\begin{array}{l}\text { 册 } \\
\text { 無 } \\
\text { H\# }\end{array}$ & $\mid \begin{array}{l}0 \\
0 \\
0\end{array}$ & $\mid \begin{array}{l}\text { 舟 } \\
\text { 無 }\end{array}$ & $\left|\begin{array}{l}H \\
H \\
t\end{array}\right|$ & \pm & + & & & \\
\hline 11 & & $\begin{array}{l}1 \\
2 \\
3 \\
4\end{array}$ & $\mid \begin{array}{l}\text { H } \\
H \\
H\end{array}$ & H & $\frac{\mathrm{HI}}{\mathrm{H}}$ & $\begin{array}{l}H \\
H \\
H\end{array}$ & 2 & \# & H & $\begin{array}{l}+ \\
+ \\
H\end{array}$ & $\begin{array}{l}\text { H } \\
\text { H } \\
\text { I }\end{array}$ & $\#$ & 1 & $t$ & $\bar{z}$ & $\begin{array}{l}\text { M } \\
\text { W } \\
\text { W }\end{array}$ & H & $\frac{1}{4}$ & $1 \frac{1}{7}$ & 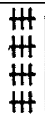 & $=$ & 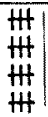 & $\mid \begin{array}{c}+ \\
+ \\
+ \\
+\end{array}$ & & 8 & & 1 & \\
\hline 12 & & $\begin{array}{l}1 \\
2 \\
3\end{array}$ & $\frac{ \pm}{2}$ & 無 & 無 & 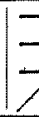 & 3 & $\begin{array}{r}+ \\
H \\
+ \\
+\end{array}$ & & $=$ & $\begin{array}{l}\text { 再 } \\
\text { 严 }\end{array}$ & $\bar{z}$ & 2 & 1 & $\begin{array}{l}\bar{z} \\
\bar{y}\end{array}$ & $\mid \begin{array}{l}\text { H } \\
\text { m } \\
\text { H }\end{array}$ & 每 & $\frac{1}{6}$ & $\frac{1}{2}$ & 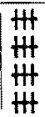 & $\bar{z}$ & 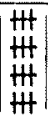 & $\left|\begin{array}{l}+ \\
+ \\
H \\
H\end{array}\right|$ & 0 & $t$ & & & \\
\hline 13 & $\begin{array}{l}\mathrm{K} \\
\mathrm{Y}\end{array}$ & $\begin{array}{l}1 \\
2 \\
3 \\
4 \\
\end{array}$ & $\frac{H}{7}$ & 8 & $\frac{11}{-}$ & $\begin{array}{l}+ \\
+ \\
H\end{array}$ & 4 & H & $\bar{H}$ & 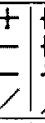 & $\begin{array}{l}H+1 \\
H \\
H\end{array}$ & $\begin{array}{l}+ \\
+ \\
\pm\end{array}$ & 3 & $H$ & $\begin{array}{l}\bar{I} \\
\bar{I}\end{array}$ & 曹 & $\frac{1}{1}$ & $\frac{1}{6}$ & $\frac{1}{\zeta}$ & $\begin{array}{l}H \\
\text { W } \\
\text { H } \\
H\end{array}$ & $|=|$ & $\begin{array}{l}H \\
H \\
H \\
H\end{array}$ & $\left|\begin{array}{c}+ \\
+ \\
+ \\
y\end{array}\right|$ & & 0 & & + & \\
\hline 14 & 2 & $\begin{array}{l}1 \\
2 \\
3 \\
4 \\
\end{array}$ & $\frac{ \pm}{2}$ & 14 & $\frac{H}{\text { H }}$ & $\begin{array}{l}+ \\
+ \\
+\end{array}$ & 3 & H & & $\frac{1}{4}$ & $\begin{array}{l}+ \\
+ \\
+ \\
+\end{array}$ & $\begin{array}{l}+ \\
+ \\
+ \\
+\end{array}$ & 3 & + & $\begin{array}{l}9 \\
0 \\
0 \\
\end{array}$ & $\begin{array}{l}+ \\
+ \\
+\end{array}$ & $\frac{1}{4}$ & 1 & 16 & $\begin{array}{l}0 \\
0 \\
+ \\
+\end{array}$ & 10 & + & $\left|\begin{array}{l}0 \\
0 \\
+ \\
+\end{array}\right|$ & & & & $H$ & $\pi$ \\
\hline 15 & $\begin{array}{l}\text { M. } \\
\text { I }\end{array}$ & $\begin{array}{l}1 \\
2 \\
3 \\
4\end{array}$ & $\frac{\mathrm{H}}{2}$ & 想 & $\bar{I}$ & $\begin{array}{r}+ \\
+ \\
H\end{array}$ & & H & & $\frac{H}{4}$ & 巠 & $\begin{array}{l}H \\
+ \\
H\end{array}$ & & _ & z & $\begin{array}{l}H \\
\text { H } \\
\text { H }\end{array}$ & \% & H & $\overline{-}$ & $\begin{array}{l}H \\
H \\
H\end{array}$ & $\left|\begin{array}{l}0 \\
0 \\
0\end{array}\right|$ & $\begin{array}{l}+ \\
+ \\
H\end{array}$ & $\begin{array}{l}+ \\
+ \\
+\end{array}$ & 9 & 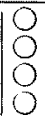 & & $\mathrm{HH}$ & + \\
\hline
\end{tabular}




\begin{tabular}{|c|c|c|c|c|c|c|c|c|c|c|c|c|c|c|c|c|c|c|c|c|c|c|c|c|c|}
\hline \multirow[t]{3}{*}{ 定 } & \multirow{2}{*}{$\begin{array}{l}\text { 断 } \\
\text { 層 }\end{array}$} & \multicolumn{4}{|c|}{ 上 } & \multicolumn{2}{|c|}{ 頻 } & \multicolumn{3}{|c|}{ 洞 } & & & \multicolumn{2}{|c|}{ 骨 洞 } & \multicolumn{2}{|c|}{ 蝶形洞 } & \multicolumn{3}{|c|}{ 鼻 } & \multicolumn{4}{|c|}{ 内 } & \multicolumn{2}{|c|}{ 翼状笑起 } \\
\hline & & & 铪 & & 醧 & & & & & 影 & & & & & & & 下略 & $介$ & 中畄 & 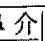 & & 中 & & 形 & 险 \\
\hline & 面 & $f$ & 下 & 内 & 外 & $\begin{array}{l}\text { 不 } \\
\text { 規 } \\
\text { 則 }\end{array}$ & & 上 & 下 & & & $\begin{array}{l}\text { 状 } \\
\text { 板 }\end{array}$ & 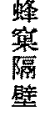 & 影 & 廍 & 影 & 骨 & 軟 & 骨 & 軟 & 骨 & & $\begin{array}{l}\text { 対 } \\
\text { 倒 } \\
\text { 典 }\end{array}$ & 態 & 影 \\
\hline
\end{tabular}

$10 \mathrm{E} \mid$\begin{tabular}{l}
2 \\
\hline
\end{tabular}

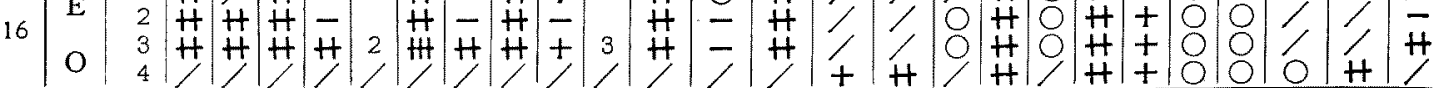

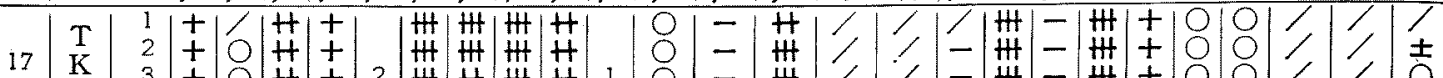

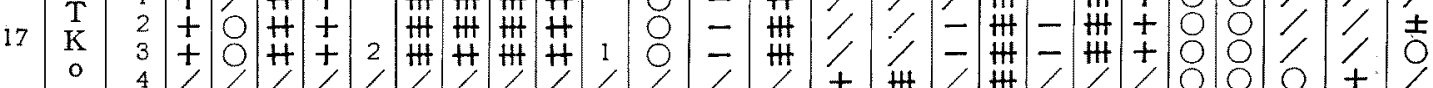

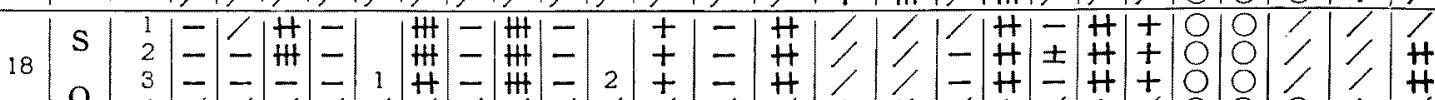

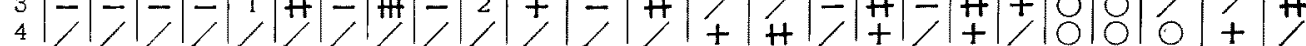

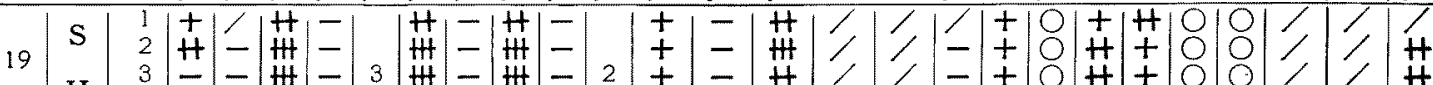

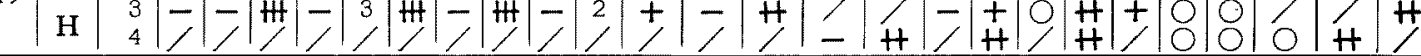

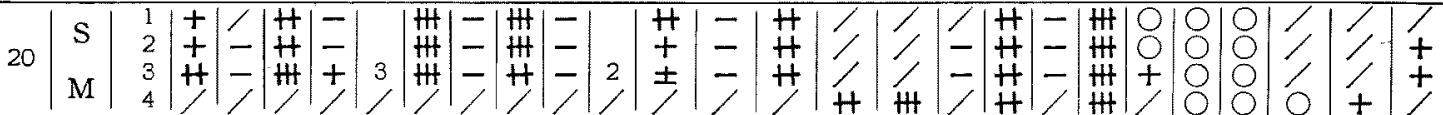

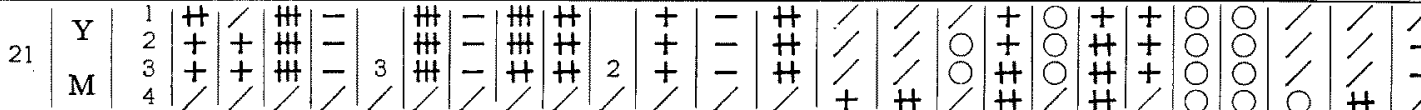

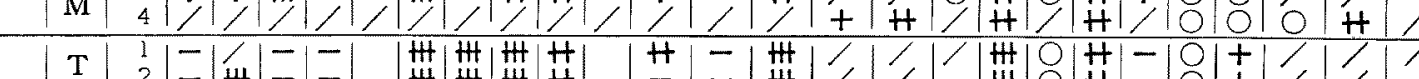
$22 \mathrm{~T} \quad 22=\mathrm{m}=$ 三 ${ }_{23}|\mathrm{~S}| \begin{aligned} & 2 \\ & \end{aligned}$ $23 \mathrm{~s} \mid \begin{aligned} & 3 \\ & \mathrm{n}\end{aligned}$

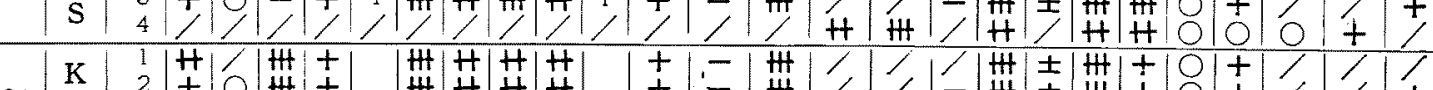
$24 \mathrm{~K} \quad 20 \begin{aligned} & + \\ & \mathbf{H}\end{aligned}$ A $\quad \begin{aligned} & 3 \\ & 4\end{aligned} \mid \begin{aligned} & \text { t } \\ & \text { y }\end{aligned}$

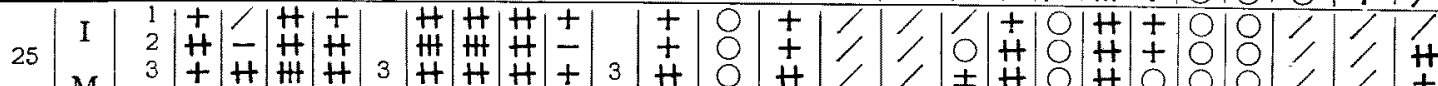

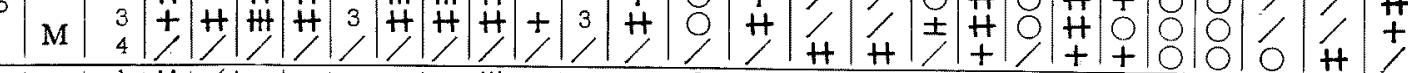

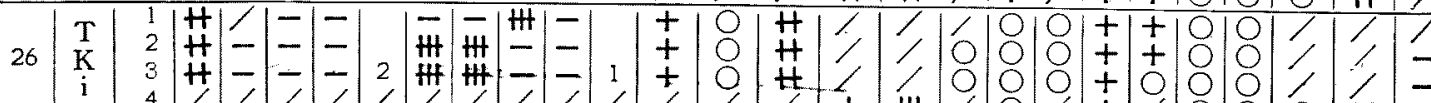

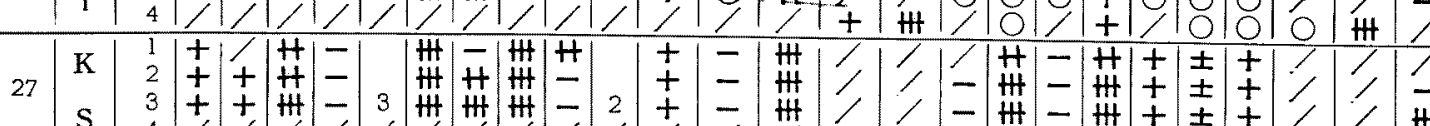

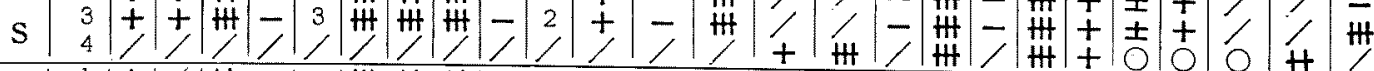

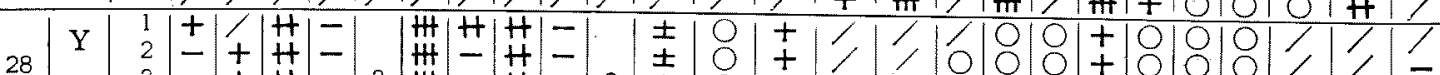
W $3-+H=3$ H $=$ H

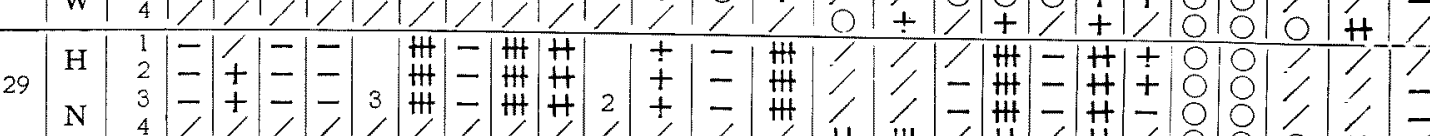

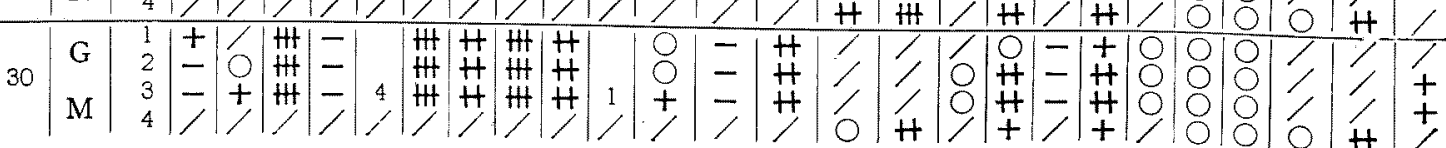


表 7 矢 状断層撮影所見

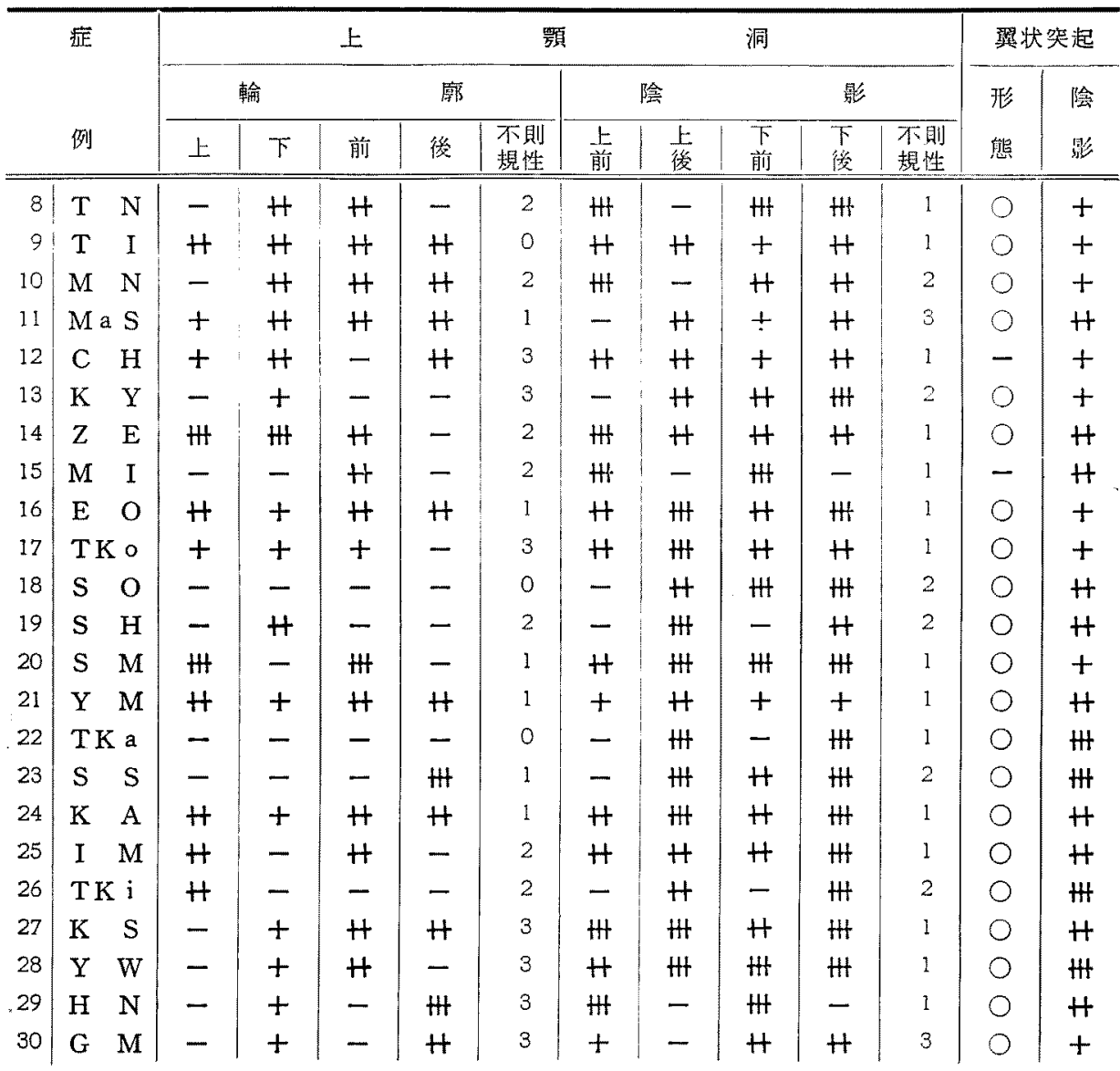

（H）（十）（士）（O）は夫ヶ完全消失，不完全消失， 消失の疑わしいるの，正常を示す。

\section{a) 上颚洞陰影}

不規則性 3 が 1 例, 2 が 4 例， 1 が 21 例， 0 が 4 例で， 大多数の例が不規則性を示すが，後頭前頭撮影比批るる 所見より不規則性がやや弱い.

b) 上顎洞上壁 (表 12)

正常例 4 例全てが X 線上軽度乃至中等度厚化を，骨 侵繁例 6 例全てが中等度乃至高度厚化を示し，骨欠損例 20 例中 16 例が断絶・消失を示寸が，4 例は中等度乃至 高度厚化を示す一致率は $22 / 30$ で，後頭前頭撮影より かなり良い

c) 上顎洞下壁 (表 14)

正常例 5 例中 3 例が $\mathrm{X}$ 線上も正常であるが， 2 例は
軽度か高度厚化を，粘膜侵翼例 1 例が中等度厚化を，骨 侵婯例 4 例全てが軽度乃至中等度厚化を示し，骨欠損例 9 例中 7 例が断絶・消失を示すが，2 例は中等度乃至高 度厚化を示す。一致率は15/19で, 後頭前頭撮影よりや や良い。

d）上顎洞内壁 (表 16)

正常例 1 例が軽度厚化を，骨侵翼例 5 例全てが軽度乃 至高度厚化を示し，骨欠損例 24 例中 19 例が断絶・消失 を示寺が，5例は中等度乃至高度厚化を示す．一致率は 24/30で，後頭前頭撮影よりかなり良い。

e).上買洞外壁 (表 18)

正常例 2 例中 1 例が正常で，他は軽度厚化を，骨侵渗 例 9 例全てが 軽度乃至高度厚化を示し，骨'久損例 19 例 中 14 例が断絶・消失を示寸が，5例は中等度乃至高度 
表 8 水平断層撮影所見

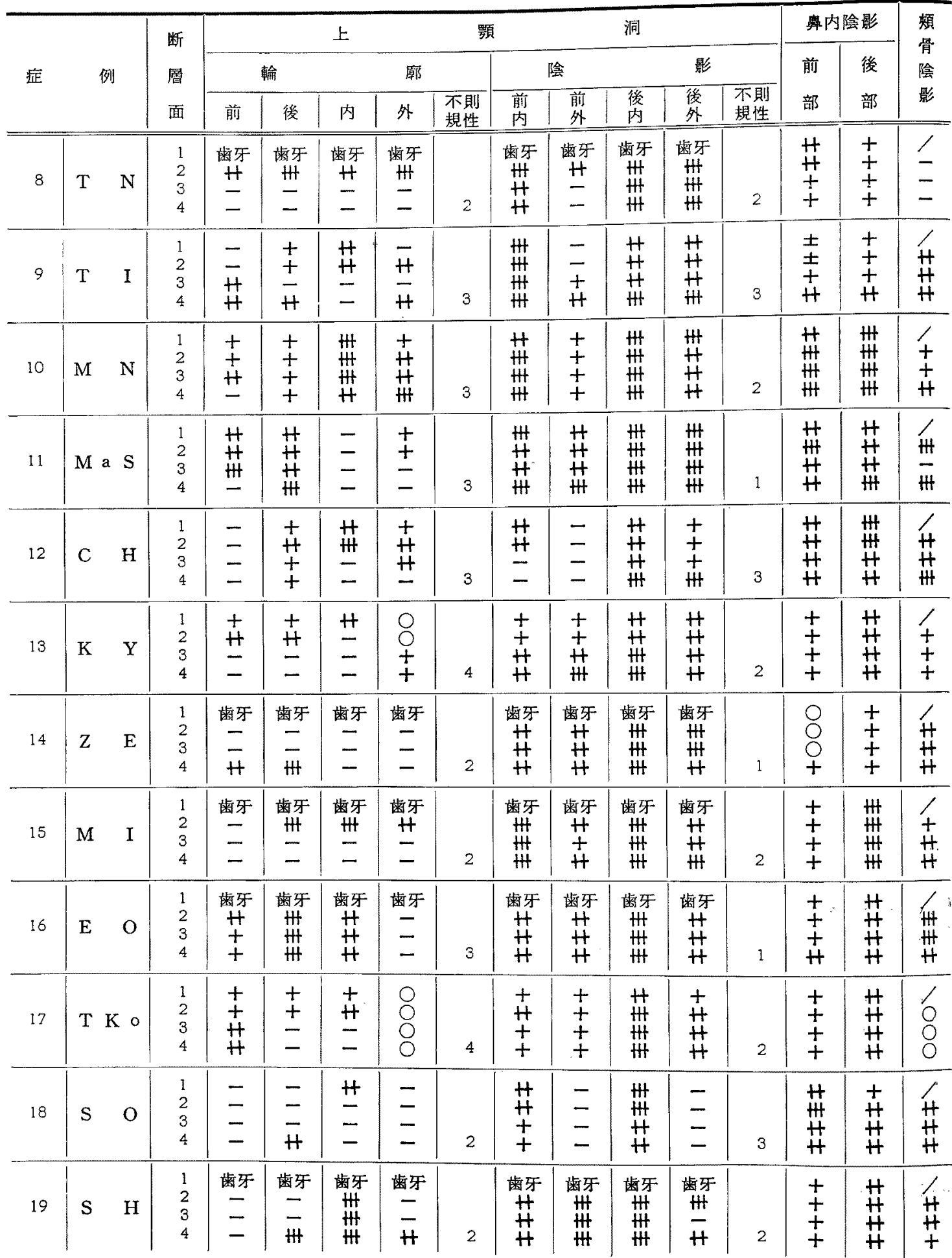




\begin{tabular}{|c|c|c|c|c|c|c|c|c|c|c|c|c|c|c|c|}
\hline \multirow{3}{*}{ 症 } & \multirow{3}{*}{ 例 } & \multirow{3}{*}{$\begin{array}{l}\text { 断 } \\
\text { 層 } \\
\text { 面 }\end{array}$} & \multicolumn{4}{|c|}{ 上 } & \multicolumn{2}{|c|}{ 顎 } & \multicolumn{4}{|c|}{ 洞 } & \multicolumn{2}{|c|}{ 勫内陰影 } & \multirow{3}{*}{$\begin{array}{l}\text { 䫅 } \\
\text { 骨 } \\
\text { 珗 } \\
\text { 影 } \\
\end{array}$} \\
\hline & & & \multicolumn{2}{|c|}{ 輪 } & \multicolumn{3}{|c|}{ 瘒 } & \multicolumn{2}{|c|}{ 陰 } & \multicolumn{3}{|c|}{ 影 } & \multirow{2}{*}{$\begin{array}{l}\text { 前 } \\
\text { 部 }\end{array}$} & \multirow{2}{*}{$\begin{array}{l}\text { 後 } \\
\text { 部 }\end{array}$} & \\
\hline & & & 前 & 後 & 内 & 外 & $\begin{array}{l}\text { 不則 } \\
\text { 規性 } \\
\end{array}$ & $\begin{array}{l}\text { 前 } \\
\text { 内 }\end{array}$ & $\begin{array}{l}\text { 前 } \\
\text { 外 }\end{array}$ & $\begin{array}{l}\text { 後 } \\
\text { 内 } \\
\end{array}$ & $\begin{array}{l}\text { 後 } \\
\text { 外 } \\
\end{array}$ & $\begin{array}{l}\text { 不則 } \\
\text { 規性 } \\
\end{array}$ & & & \\
\hline 20 & $S \quad M$ & $\begin{array}{l}1 \\
2 \\
3 \\
4\end{array}$ & $\frac{1}{=}$ & $\frac{-}{+}$ & $\begin{array}{c}\text { 蒾牙 } \\
\frac{\mathrm{H}}{-} \\
-\end{array}$ & $\frac{\sqrt{4}}{-}$ & 3 & $\begin{array}{c}\text { 歯牙 } \\
\text { H } \\
\text { H } \\
\text { H }\end{array}$ & $\begin{array}{c}\text { 畨牙 } \\
\text { H } \\
+ \\
\text { H }\end{array}$ & $\begin{array}{c}\text { 歯牙 } \\
\text { H } \\
\text { H } \\
\text { Ht }\end{array}$ & $\begin{array}{c}\text { 歯牙 } \\
\text { H } \\
\text { H } \\
\text { H }\end{array}$ & 1 & $\begin{array}{l}+ \\
H \\
H \\
H\end{array}$ & $\begin{array}{l}H \\
H \\
H \\
H\end{array}$ & $\begin{array}{l}+ \\
+ \\
+\end{array}$ \\
\hline 21 & $\mathrm{Y} \quad \mathrm{M}$ & $\begin{array}{l}1 \\
2 \\
3 \\
4 \\
\end{array}$ & $\begin{array}{l}+ \\
+ \\
+\end{array}$ & $\begin{array}{l}- \\
\text { H }\end{array}$ & $\begin{array}{l}H \\
H \\
H \\
H\end{array}$ & $\begin{array}{l}\bar{t} \\
\bar{t}\end{array}$ & 3 & $\begin{array}{l}+ \\
+ \\
+ \\
+\end{array}$ & $\begin{array}{l}+ \\
+ \\
+ \\
+\end{array}$ & $\begin{array}{l}H \\
H \\
H \\
H\end{array}$ & $\begin{array}{l}\vec{H} \\
H \\
+\end{array}$ & 3 & $\begin{array}{l}H \\
H \\
H \\
+\end{array}$ & $\begin{array}{l}H \\
H \\
H \\
H\end{array}$ & $\frac{1}{H}$ \\
\hline 22 & $\mathrm{~T} \mathrm{Ka}$ & $\begin{array}{l}1 \\
2 \\
3 \\
4 \\
\end{array}$ & $\bar{z}$ & $\begin{array}{l}- \\
H \\
H\end{array}$ & $\begin{array}{l}\text { 册 } \\
-\end{array}$ & $\begin{array}{l}\overline{+} \\
+ \\
+\end{array}$ & 3 & $\begin{array}{l}\text { H } \\
\text { H } \\
\text { H }\end{array}$ & $\begin{array}{l}\text { 圱 } \\
\text { H } \\
\text { H }\end{array}$ & $\begin{array}{l}H+H \\
H \\
H \\
H\end{array}$ & $\begin{array}{l}H \\
H \\
H \\
H\end{array}$ & 1 & $\begin{array}{l}H \\
H \\
H \\
H\end{array}$ & $\begin{array}{l}\text { 册 } \\
\text { H } \\
\text { H } \\
H\end{array}$ & $\frac{r}{H}$ \\
\hline 23 & $\mathrm{~S}$ & $\begin{array}{l}1 \\
2 \\
3 \\
4 \\
\end{array}$ & $\begin{array}{l}\bar{H} \\
\mathrm{H} \\
+\end{array}$ & $\begin{array}{l}+ \\
+ \\
+ \\
+\end{array}$ & $\frac{-}{m}$ & $\begin{array}{l}+ \\
+ \\
+ \\
+\end{array}$ & 3 & $\begin{array}{l}\text { H } \\
\text { H } \\
+ \\
+\end{array}$ & $\begin{array}{l}H \\
H \\
H \\
H\end{array}$ & $\begin{array}{l}+ \\
\text { H } \\
\text { H } \\
\text { H }\end{array}$ & $\begin{array}{l}H \\
H \\
H \\
H\end{array}$ & 2 & $\begin{array}{l}\text { W } \\
\text { H } \\
\text { W } \\
\text { H }\end{array}$ & $\begin{array}{l}\text { H } \\
\text { 册 } \\
\text { 册 } \\
\text { 世 }\end{array}$ & $\begin{array}{l}+ \\
+ \\
+\end{array}$ \\
\hline 24 & $\mathrm{~K} \quad \mathrm{~A}$ & $\begin{array}{l}1 \\
2 \\
3 \\
4\end{array}$ & $\underset{H}{H}$ & $\begin{array}{l}+ \\
+ \\
+\end{array}$ & $\begin{array}{l}\text { W } \\
H \\
H \\
H\end{array}$ & $\begin{array}{l}+ \\
+ \\
+ \\
+\end{array}$ & 2 & $\begin{array}{l}H \\
H \\
H \\
H\end{array}$ & $\begin{array}{l}H \\
H \\
H \\
H\end{array}$ & $\begin{array}{l}H \\
H \\
H \\
H\end{array}$ & $\begin{array}{l}H \\
H \\
H \\
H\end{array}$ & 1 & $\begin{array}{l}\text { W } \\
\text { W } \\
H \\
H\end{array}$ & $\begin{array}{l}\text { H } \\
\text { W } \\
\text { W }\end{array}$ & $\begin{array}{l}H \\
+ \\
H\end{array}$ \\
\hline 25 & I $\quad M$ & $\begin{array}{l}1 \\
2 \\
3 \\
4\end{array}$ & $\begin{array}{l}+ \\
+ \\
+\end{array}$ & $\begin{array}{l}\overline{-} \\
\mathrm{H}\end{array}$ & $\begin{array}{l}\text { H } \\
\text { H } \\
\text { H } \\
H\end{array}$ & $\begin{array}{l}+ \\
H \\
+ \\
+\end{array}$ & 3 & $\begin{array}{l}H \\
H \\
H \\
H\end{array}$ & $\begin{array}{l}+ \\
+ \\
+\end{array}$ & $\begin{array}{l}H \\
H \\
H \\
H\end{array}$ & $\begin{array}{l}\text { H } \\
\text { H } \\
H \\
H\end{array}$ & 2 & $\begin{array}{l}H \\
H \\
H \\
H\end{array}$ & $\begin{array}{l}H \\
H \\
H \\
H\end{array}$ & $\begin{array}{l}H \\
H \\
+\end{array}$ \\
\hline 26 & $\mathrm{~T} \mathrm{~K} \mathrm{i}$ & $\begin{array}{l}1 \\
2 \\
3 \\
4\end{array}$ & $\begin{array}{l}\text { 曲 } \\
\frac{H}{-}\end{array}$ & $\begin{array}{l}\overline{-} \\
+\end{array}$ & $\begin{array}{l}\text { H } \\
= \\
-\end{array}$ & $\begin{array}{l}\overline{-} \\
\bar{t}\end{array}$ & 3 & $\begin{array}{l}H \\
H \\
H \\
H\end{array}$ & $\begin{array}{l}H \\
H \\
H \\
H\end{array}$ & $\begin{array}{l}+\# \\
H \\
H \\
H\end{array}$ & $\begin{array}{l}H \\
H \\
H \\
H\end{array}$ & 1 & $\begin{array}{l}H \\
H \\
H \\
H\end{array}$ & $\begin{array}{l}H \\
W \\
W \\
W\end{array}$ & $\begin{array}{l}H \\
H \\
H\end{array}$ \\
\hline 27 & $\mathrm{~K}$ & $\begin{array}{l}1 \\
2 \\
3 \\
4\end{array}$ & $\begin{array}{l}\bar{H} \\
H \\
H\end{array}$ & $\begin{array}{c}\text { 歯牙 } \\
+ \\
- \\
-\end{array}$ & $\begin{array}{l}H \\
H \\
H\end{array}$ & $\begin{array}{l}\overline{-} \\
\bar{H}\end{array}$ & 2 & $\begin{array}{l}H \\
H \\
H \\
H\end{array}$ & $\begin{array}{l}\text { H } \\
H \\
H \\
H\end{array}$ & $\begin{array}{l}\text { H } \\
\text { H } \\
H \\
H+H\end{array}$ & $\begin{array}{l}H \\
H \\
H \\
H\end{array}$ & 1 & $\begin{array}{l}H \\
H \\
H \\
H\end{array}$ & $\begin{array}{l}\text { H } \\
\text { H } \\
\mathrm{Ht}\end{array}$ & $\frac{-}{m}$ \\
\hline 28 & $\mathrm{Y} \quad \mathrm{W}$ & $\begin{array}{l}1 \\
2 \\
3 \\
4\end{array}$ & $\begin{array}{l}- \\
H \\
H\end{array}$ & $\frac{\bar{z}}{\bar{H}}$ & $\begin{array}{l}\text { H } \\
\text { 無 } \\
\text { H }\end{array}$ & $\frac{\bar{z}}{\bar{H}}$ & 2 & $\begin{array}{l}H \\
H \\
H \\
H\end{array}$ & $\begin{array}{l}H \\
H \\
H \\
H\end{array}$ & $\begin{array}{l}H \\
H \\
H \\
H\end{array}$ & $\begin{array}{l}H \\
H \\
H \\
H\end{array}$ & 1 & $\begin{array}{l}H \\
+ \\
+ \\
H\end{array}$ & $\begin{array}{l}H \\
H \\
H \\
H\end{array}$ & $\frac{1}{H}$ \\
\hline 29 & $\mathrm{H} \quad \mathrm{N}$ & $\begin{array}{l}1 \\
2 \\
3 \\
4 \\
\end{array}$ & 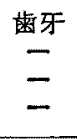 & $\begin{array}{l}\text { 歯牙 } \\
= \\
-\end{array}$ & $\begin{array}{c}\text { 歯牙 } \\
= \\
=\end{array}$ & $\begin{array}{c}\text { 㭔牙 } \\
- \\
-\end{array}$ & 0 & 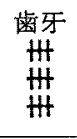 & 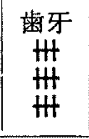 & $\begin{array}{c}\text { 歯牙 } \\
H \\
H \\
H \\
H\end{array}$ & $\begin{array}{c}\text { 歯牙 } \\
\text { H } \\
\text { H } \\
\text { H }\end{array}$ & 0 & $\begin{array}{l}\text { H } \\
\text { W } \\
\text { H } \\
\text { H }\end{array}$ & $\begin{array}{l}\text { H } \\
\text { H } \\
\text { H } \\
H\end{array}$ & $\underline{z}$ \\
\hline 30 & G $\quad M$ & $\begin{array}{l}1 \\
2 \\
3 \\
4\end{array}$ & $\begin{array}{c}\text { 歯牙 } \\
H \\
H \\
H\end{array}$ & $\frac{\text { 畨牙 }}{\mathrm{Ht}}$ & $\begin{array}{c}\text { 歯牙 } \\
= \\
=\end{array}$ & $\frac{\text { 歯牙 }}{=}$ & 3 & $\begin{array}{c}\text { 觜牙 } \\
\text { H } \\
+ \\
+\end{array}$ & $\begin{array}{c}\text { 歯牙 } \\
\mathrm{H} \\
\mathrm{H} \\
+\end{array}$ & $\begin{array}{c}\text { 歯牙 } \\
\text { H } \\
\text { H } \\
\text { H }\end{array}$ & $\begin{array}{c}\text { 歯牙 } \\
+ \\
H \\
H\end{array}$ & 2 & $\begin{array}{l}+ \\
+ \\
+ \\
+\end{array}$ & $\begin{array}{l}H \\
H \\
H \\
H\end{array}$ & $\begin{array}{l}\text { H } \\
+ \\
+\end{array}$ \\
\hline
\end{tabular}


表 9 源道造影撮影所見

\begin{tabular}{|c|c|c|c|c|c|c|c|c|c|c|c|c|c|c|}
\hline \multicolumn{3}{|c|}{ 症例 } & \multicolumn{4}{|c|}{ 露 } & \multicolumn{8}{|c|}{ 管 } \\
\hline 番 & \multirow{2}{*}{\multicolumn{2}{|c|}{ 名 }} & \multirow{2}{*}{$\begin{array}{l}\text { 輪 } \\
\frac{\text { 正 }}{\text { 面 }}\end{array}$} & 廓 & \multicolumn{2}{|l|}{ 拆 } & 輸 & 廊 & 狭 & 窄 & \multicolumn{2}{|c|}{ 「モ」影淡化 } & \multicolumn{2}{|c|}{ 走行異常 } \\
\hline 号 & & & & $\begin{array}{l}\text { 侧 } \\
\text { 面 }\end{array}$ & $\begin{array}{l}\text { 正 } \\
\text { 面 } \\
\end{array}$ & $\begin{array}{l}\text { 側 } \\
\text { 面 }\end{array}$ & 正 & $\begin{array}{l}\text { 側 } \\
\text { 面 } \\
\end{array}$ & $\begin{array}{l}\text { 正 } \\
\text { 面 }\end{array}$ & $\begin{array}{l}\text { 側 } \\
\text { 面 } \\
\end{array}$ & $\begin{array}{l}\text { 正 } \\
\text { 面 }\end{array}$ & $\begin{array}{l}\text { 䞂 } \\
\text { 面 }\end{array}$ & $\begin{array}{l}\text { 正 } \\
\text { 面 }\end{array}$ & 側 \\
\hline 1 & I & $\mathrm{U}$ & 平 & 平 & $H$ & - & I & 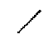 & $\gamma$ & ノ & I & I & 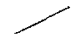 & \\
\hline 2 & & & 平 & 平 & + & - & 平 & 波 & $H$ & + & + & + & 内方 & 前方 \\
\hline 3 & $\mathrm{Mi}$ & & $\bar{F}$ & 平 & - & - & Y & 波 & ノ & H & $\nearrow$ & $H$ & & 前方 \\
\hline 4 & $\mathrm{H}$ & & 平 & $\sqrt{2}$ & $H$ & $H$ & 平 & 波 & $H$ & - & $t$ & - & 内方 & 一 \\
\hline 5 & $\mathrm{M}$ & & 波 & 波 & $\mathrm{HH}$ & $H$ & $\vec{y} \bar{x}$ & 平 & + & $t$ & $H$ & $H$ & 内方 & 前方 \\
\hline 6 & $\mathrm{O}$ & $\mathrm{M}$ & 平 & 平 & \# & $H$ & $\bar{F}$ & 平 & $H$ & $H$ & - & - & 内方 & 前方 \\
\hline 7 & $\mathrm{H}$ & & 波 & 波 & + & + & 波 & 波 & $\mathrm{HH}$ & - & - & - & 内方 & - \\
\hline 8 & $\mathrm{~T}$ & $\mathrm{~N}$ & 平 & 平 & - & - & 波 & 平 & $H$ & $H$ & + & $H$ & 内方 & 前方 \\
\hline 9 & $T$ & I & 平 & 波 & - & - & 平 & 波 & $\mathrm{HH}$ & H & \pm & + & 内方 & 前方 \\
\hline 10 & $\mathrm{M}$ & $\mathrm{N}$ & 波 & 波 & - & - & & & 成 & & & 塞 & & \\
\hline 11 & $\mathrm{Ma}$ & & 波 & 波 & $H$ & $H$ & 平 & 平 & $H$ & H & $t$ & + & 内方 & 前方 \\
\hline 12 & $\mathrm{C}$ & $\mathrm{H}$ & 平 & 平 & $H$ & $\mathrm{HH}$ & & & P & & & 塞 & & \\
\hline 13 & $\mathrm{~K}$ & $\mathrm{Y}$ & 平 & 平 & $H$ & $H$ & iा & 波 & $H$ & H & - & $H$ & 内方 & 前方 \\
\hline 14 & $Z$ & $E$ & 波 & 波 & + & - & 푸 & 波 & + & + & - & - & 内方 & 前方 \\
\hline 15 & $\mathrm{M}$ & I & 平 & 波 & - & - & 波 & 波 & $H$ & $H$ & $t$ & + & 内方 & 前方 \\
\hline 16 & $\mathrm{E}$ & $O$ & 平 & 平 & - & - & 波 & 波 & $H$ & $t$ & + & + & - & 後方 \\
\hline 17 & TK & & 平 & 平 & - & - & 波 & 波 & $H$ & H & $H$ & + & - & 前方 \\
\hline 18 & S & O & 平 & 平 & + & - & 波 & I & \# & $\gamma$ & - & $\checkmark$ & - & \\
\hline 19 & $\mathrm{~S}$ & $\mathrm{H}$ & 波 & 波 & - & - & & & 屏 & & & 塞 & & \\
\hline 20 & & & 波 & 波 & + & - & 波 & 波 & $H$ & + & + & + & - & 前方 \\
\hline 21 & $\mathrm{Y}$ & $\mathrm{M}$ & 波 & 波 & - & - & 波 & 波 & $H$ & + & + & + & 内方 & 前方 \\
\hline 22 & TK & & 波 & 波 & - & - & 波 & 波 & H & $H$ & + & + & 内方 & 後方 \\
\hline 23 & $S$ & $S$ & 푸 & 平 & + & - & 波 & 波 & $H$ & $H$ & $H$ & + & 内方 & 前方 \\
\hline 24 & $\mathrm{~K}$ & & 平 & 波 & - & - & & & B & & & 塞 & & \\
\hline 25 & & $\mathrm{M}$ & 波 & 波 & - & - & 波 & 波 & + & $H$ & + & + & - & - \\
\hline 26 & TK & & 平 & 波 & - & - & 波 & 波 & + & $H$ & + & + & 内方 & 前方 \\
\hline 27 & $\mathrm{~K}$ & & 波 & 波 & $H$ & $H$ & 波 & r & $\mathrm{HH}$ & 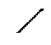 & + & $\nearrow$ & 内方 & $\gamma$ \\
\hline 28 & $Y$ & W & 波 & 波 & - & - & 波 & 波 & $H$ & $H$ & + & + & - & 前方 \\
\hline 29 & $\mathrm{H}$ & $\mathrm{N}$ & 波 & 波 & $H$ & - & 波 & 波 & $H$ & $\mathrm{H}$ & + & + & 内方 & 後方 \\
\hline 30 & $\mathrm{G}$ & $\mathrm{M}$ & 波 & 波 & - & - & 波 & 波 & + & - & + & + & 内方 & - \\
\hline
\end{tabular}

厚化を示す一致率は24/30で，後頭前頭撮影と殆ど同 じである，又，各壁陰影の不規則性は 30 例中 24 例で認 められる。

f）眼简下孔と上顎洞上壁との関係（表 23）

上壁正常例 4 例中 3 例が X 線上眼简下孔正常で, 1 例は眼窩下孔の 崩壊疑わしきものであり，骨侵曧例 6 例中 2 例怯不完全乃至完全消失を示すが，3例は疑放し もの，1例怔常である，骨次損例 20 例中 16 例が完
全乃至不完全消失を示すが，4例凝わしき るのであ る.一致率は 24/30である。

g) 紙状板之篩骨蜂䆞之の関係（表 24）

節骨蜂杲正常例 7 例中 2 例か: X 線上紙状板も正常で， 5 例は軽度乃至高度厚化を, 軽度侵筫例 13 例全てが軽 度乃至高度厚化を示し，高度侵筑例 10 例中 4 例が断絶・ 消失を，5例が軽度乃至高度厚化を示すが，1 例は正常

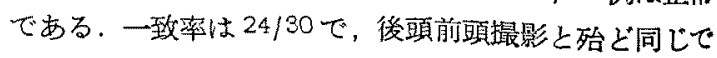


表 10 外頞動脈造影撮影所見（对照)

\begin{tabular}{|c|c|c|c|c|c|c|c|c|c|}
\hline \multicolumn{2}{|l|}{ 症 } & \multicolumn{2}{|c|}{ 䝷動脈 } & \multicolumn{2}{|c|}{$\begin{array}{l}\text { 腿窝下 } \\
\text { 動 脈 }\end{array}$} & \multirow{2}{*}{ 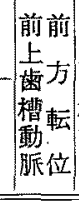 } & \multirow{2}{*}{ 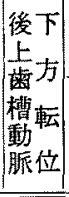 } & \multicolumn{2}{|c|}{$\begin{array}{l}\text { 䚇口蓋 } \\
\text { 動 }\end{array}$} \\
\hline 名 & 断 & $\begin{array}{l}\text { 後転 } \\
\text { 方位 }\end{array}$ & $\begin{array}{l}\text { 側 } \\
\text { 方 } \\
\text { 転 } \\
\text { 售 }\end{array}$ & \begin{tabular}{|l|} 
起蛇 \\
始 \\
部行
\end{tabular} & $\begin{array}{l}\text { 上 } \\
\text { 方 } \\
\text { 転 } \\
\text { 立 }\end{array}$ & & & 分 & $\begin{array}{l}\text { 蛇 } \\
\text { 行 }\end{array}$ \\
\hline $\mathbf{U}$ & $\begin{array}{l}\text { 中 隔 } \\
\text { 出血性奥苗 }\end{array}$ & - & - & + & - & - & - & 密 & $t$ \\
\hline $\mathbf{Y ~ S}$ & 严 肉 腫 & - & + & + & - & - & - & 稍棵 & - \\
\hline$T$ & 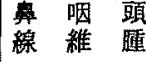 & - & + & + & + & - & - & 琜 & + \\
\hline $\mathrm{SN}$ & 鼻 梅 毒 & - & - & + & - & - & - & 疎 & - \\
\hline $\mathbf{K}$ & 番 肉 畽 & - & - & + & - & + & - & 密 & + \\
\hline MK & 鼻 出 血 & - & - & + & - & - & - & 密 & + \\
\hline A & 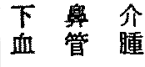 & - & - & $t$ & - & - & - & 密 & + \\
\hline K Y & 填㡺性炏 & - & - & + & - & - & - & 㻋 & - \\
\hline K D & 舌 & + & + & $t$ & - & - & - & 密 & + \\
\hline MK & 喉 頭 癌 & - & + & $t$ & - & - & - & 密 & + \\
\hline H S & 喉 頭 疽 & - & - & + & - & - & - & 密 & + \\
\hline TU & 顎下腺腫激 & - & + & + & - & - & - & 密 & + \\
\hline
\end{tabular}

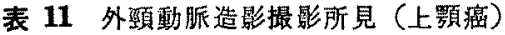

\begin{tabular}{|c|c|c|c|c|c|c|c|c|c|c|}
\hline & 㱏 & & 颚頻重 & & 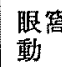 & & 前前 & 後下 & 蝶口 & 動脈 \\
\hline & 列 & & $\begin{array}{l}\text { 後転 } \\
\text { 方位 }\end{array}$ & $\begin{array}{l}\text { 側 } \\
\text { 方 } \\
\text { 檕 }\end{array}$ & $\begin{array}{l}\text { 起蛇 } \\
\text { 始 } \\
\text { 部行 }\end{array}$ & $\frac{上}{\text { 古 }}$ & $\begin{array}{l}\text { 槽転 } \\
\text { 䡃 } \\
\text { 㭽位 }\end{array}$ & 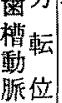 & $\begin{array}{l}\text { 分 } \\
\text { 布 }\end{array}$ & $\begin{array}{l}\text { 蛇 } \\
\text { 行 }\end{array}$ \\
\hline 1 & I & $\mathrm{U}$ & $H$ & $H$ & - & $\mathrm{HH}$ & $H$ & 0 & 密 & + \\
\hline 2 & $\mathrm{H}$ & $\mathrm{S}$ & $H$ & $H$ & $H$ & $H$ & 0 & 0 & 政 & - \\
\hline 3 & $\mathrm{M}$ & $\mathrm{S}$ & $H$ & + & + & H & 0 & $H$ & 密 & $H$ \\
\hline 4 & & $K$ & $H$ & 0 & - & H & $\mathrm{HH}$ & $H$ & 稍柾 & - \\
\hline 5 & $\mathbf{M}$ & $\mathrm{O}$ & + & + & - & HH & H & $H$ & 䟱 & - \\
\hline 6 & $\mathrm{O}$ & $\mathrm{M}$ & $H$ & + & 消 & & 消失 & 消失 & 消 & 失 \\
\hline 7 & $\mathrm{H}$ & $\mathrm{S}$ & $H$ & + & - & $\mathrm{H}$ & 0 & $\mathrm{HH}$ & 䟱 & - \\
\hline 8 & $\mathrm{~T}$ & $\mathbf{N}$ & + & $H$ & 消 & & 消失 & $H$ & 稍柾 & - \\
\hline 9 & $\mathrm{~T}$ & $\mathbf{I}$ & + & $H$ & - & $t$ & + & + & 稍眯 & - \\
\hline 10 & $\mathrm{M}$ & $\mathbf{N}$ & + & 0 & + & $H$ & $t$ & + & 稍柾 & - \\
\hline 11 & $\mathbf{M}$ & $S$ & $H$ & $H$ & $H$ & + & + & 0 & 瑓 & - \\
\hline 12 & C & $\mathrm{H}$ & \# & $\mathrm{HH}$ & $H$ & $t$ & + & + & 柾 & - \\
\hline 13 & $\mathrm{~K}$ & $\mathrm{Y}$ & $H$ & 0 & + & $H$ & + & 0 & 璉 & - \\
\hline 14 & $Z$ & $\mathrm{E}$ & + & $H$ & & + & $\mathrm{H}$ & $H$ & 稍䟱 & - \\
\hline 15 & & $\mathrm{I}$ & 0 & + & 消 & & 消失 & 消失 & 消 & 失 \\
\hline 17 & & 50 & + & + & + & + & + & + & 柾 & - \\
\hline 18 & S & $\mathrm{O}$ & $H$ & $H$ & - & + & + & $H$ & 稍眯 & - \\
\hline 19 & $S$ & $\mathrm{H}$ & $H$ & $H$ & - & H & + & + & 稍䟱 & - \\
\hline 24 & $\mathbf{K}$ & A & $H$ & $H$ & - & + & 0 & 0 & 柾 & - \\
\hline
\end{tabular}

表 12 上顎 洞上壁の所見(単純撮影)

\begin{tabular}{|c|c|c|c|c|c|c|c|c|c|c|c|c|c|c|c|}
\hline \multirow{2}{*}{$\bigvee^{\prime} \bigcup^{x}$} & \multicolumn{2}{|c|}{ 後 } & 頍 & \multicolumn{2}{|c|}{ i) 晍 } & \multicolumn{2}{|c|}{ 後 } & 頭 & \multicolumn{2}{|c|}{ 頣 } & \multicolumn{5}{|c|}{ レーゼ氏法 } \\
\hline & IE & $\begin{array}{l}\text { 慗 } \\
\text { 度 } \\
\text { 㷴 } \\
\text { 化 }\end{array}$ & $\begin{array}{l}\text { 中 } \\
\text { 等 } \\
\text { 度 } \\
\text { 㕍 } \\
\text { 华 }\end{array}$ & $\begin{array}{l}\text { 高 } \\
\text { 度 } \\
\text { 厚 } \\
\text { 化 }\end{array}$ & $\begin{array}{l}\text { 断 } \\
\text { 絶 } \\
\text { 消 } \\
\text { 失 }\end{array}$ & 常 & $\begin{array}{l}\text { 軽 } \\
\text { 度 } \\
\text { 厚 } \\
\text { 化 }\end{array}$ & $\begin{array}{l}\text { 中 } \\
\text { 等 } \\
\text { 度 } \\
\text { 厚 } \\
\text { 化 }\end{array}$ & $\begin{array}{l}\text { 㵝 } \\
\text { 度 } \\
\text { 愿 } \\
\text { 化 }\end{array}$ & $\begin{array}{l}\text { 断 } \\
\text { 絶 } \\
\text { 消 } \\
\text { 失 }\end{array}$ & 常 & $\begin{array}{l}\text { 整 } \\
\text { 度 } \\
\text { 厚 } \\
\text { 化 }\end{array}$ & $\begin{array}{l}\text { 中 } \\
\text { 等 } \\
\text { 度 } \\
\text { 厚 } \\
\text { 化 }\end{array}$ & $\begin{array}{l}\text { 高 } \\
\text { 度 } \\
\text { 厚 } \\
\text { 化 }\end{array}$ & $\begin{array}{l}\text { 断 } \\
\text { 絶 } \\
\text { 消 } \\
\text { 失 }\end{array}$ \\
\hline 正 常 & & 3 & 1 & & & & 3 & 1 & & & & 1 & 1 & & \\
\hline 粘膜侵熟 & & & & & & & & & & & & & & & \\
\hline 骨 侵 咀 & & 2 & 3 & 1 & & & & 4 & 2 & & & & 4 & 1 & \\
\hline 骨 欠損 & & & 6 & 4 & 10 & & & 2 & 2 & 16 & & & 2 & 2 & 12 \\
\hline 一致 率 & & & $5 / 3$ & & & & & $2 / 30$ & & & & & $7 /$ & & \\
\hline
\end{tabular}


表 13 上䫇洞上壁の所見（断層撮影）

\begin{tabular}{|c|c|c|c|c|c|c|c|c|c|c|}
\hline \multirow[b]{2}{*}{$\left.\underbrace{x}\right|^{x}$} & \multicolumn{2}{|c|}{ 前 } & \multicolumn{3}{|c|}{ 頭 } & \multicolumn{3}{|c|}{ 矢 } & \multicolumn{2}{|l|}{ 状 } \\
\hline & 常 & $\begin{array}{l}\text { 軽 } \\
\text { 度 } \\
\text { 厚 } \\
\text { 化 }\end{array}$ & $\begin{array}{l}\text { 中 } \\
\text { 等 } \\
\text { 度 } \\
\text { 㕌 } \\
\text { 化 }\end{array}$ & $\begin{array}{l}\text { 高 } \\
\text { 度 } \\
\text { 厚 } \\
\text { 化 }\end{array}$ & $\begin{array}{l}\text { 断 } \\
\text { 絶 } \\
\text { 消 } \\
\text { 失 }\end{array}$ & 常 & $\begin{array}{l}\text { 晆 } \\
\text { '度 } \\
\text { 厚 } \\
\text { 化 }\end{array}$ & $\begin{array}{l}\text { 中 } \\
\text { 等 } \\
\text { 度 } \\
\text { 檿 } \\
\text { 化 }\end{array}$ & $\begin{array}{l}\text { 商 } \\
\text { 度 } \\
\text { 曆 } \\
\text { 化 }\end{array}$ & $\begin{array}{l}\text { 断 } \\
\text { 絶 } \\
\text { 消 } \\
\text { 失 }\end{array}$ \\
\hline 正 常 & & 1 & 3 & & & & & 2 & & \\
\hline 粘膜侵競 & & & & & & & & & & \\
\hline 骨 侵 襲 & & 2 & 4 & & & & 3 & 4 & 2 & \\
\hline 骨 欠損 & & 2 & 1 & 1 & 16 & & & & & 12 \\
\hline 一致 象 & & & $/ 3$ & & & & & $21 / 2$ & & \\
\hline
\end{tabular}

ある。

h) 前 頭 洞

$\mathrm{X}$ 線上輪廓は 22 例中 17 例で軽度, 2 例で中等度厚化 を示し，除影は 1 例以外の全てで増強し，半数以上は中 等度以上の增強を示す。

3) 軸位撮影（表4)

表中「下㖽骨」とあるのは下顎骨の重盢による上䫜洞 後壁の読影不能を示す 翼状突起形態の項での (一), (○)は夫々変形, 正常を示す.

a)上顎洞後壁（表21）

骨侵融例 8 例全てが軽度乃至高度厚化を示し，骨久損 例 18 例中 9 例が断絶・消失を゙示すが，他の 9 例は中等 度乃至高度厚化を示寸一致率は17/26 と低率である。

表 14 上靧洞下壁の所見(単純撮影)

\begin{tabular}{|c|c|c|c|c|c|c|c|c|c|c|c|c|c|c|c|}
\hline \multirow[b]{2}{*}{$\bigcup^{x}$} & \multicolumn{2}{|r|}{ 徭 } & & \multicolumn{2}{|c|}{ ij 頭 } & \multicolumn{2}{|c|}{ 後 } & 頭 & \multicolumn{2}{|c|}{ 顋 } & \multicolumn{5}{|c|}{ レーゼ氏法 } \\
\hline & 常 & $\begin{array}{l}\text { 軽 } \\
\text { 度 } \\
\text { 厚 } \\
\text { 化 }\end{array}$ & $\begin{array}{l}\text { 中 } \\
\text { 等 } \\
\text { 度 } \\
\text { 願 } \\
\text { 化 }\end{array}$ & $\begin{array}{l}\text { 高 } \\
\text { 度 } \\
\text { 厚 } \\
\text { 化 }\end{array}$ & $\begin{array}{l}\text { 断 } \\
\text { 絶 } \\
\text { 消 } \\
\text { 失 }\end{array}$ & 常 & $\begin{array}{l}\text { 㪕 } \\
\text { 度 } \\
\text { 厚 } \\
\text { 化 }\end{array}$ & $\begin{array}{l}\text { 中 } \\
\text { 等 } \\
\text { 喥 } \\
\text { 㿞 } \\
\text { 化 }\end{array}$ & $\begin{array}{l}\text { 高 } \\
\text { 度 } \\
\text { 擪 } \\
\text { 化 }\end{array}$ & $\begin{array}{l}\text { 断 } \\
\text { 䋓 } \\
\text { 消 } \\
\text { 失 }\end{array}$ & 常 & $\begin{array}{l}\text { 軽 } \\
\text { 度 } \\
\text { 厚 } \\
\text { 化 }\end{array}$ & $\begin{array}{l}\text { 中 } \\
\text { 等 } \\
\text { 度 } \\
\text { 㕌 } \\
\text { 化 }\end{array}$ & $\begin{array}{l}\text { 高 } \\
\text { 度 } \\
\text { 愿 } \\
\text { 化 }\end{array}$ & $\begin{array}{l}\text { 断 } \\
\text { 紿 } \\
\text { 消 } \\
\text { 失 }\end{array}$ \\
\hline IF 常 & 4 & 4 & 2 & & & 3 & 1 & & 1 & & & 4 & 3 & & \\
\hline 粘膜侵熟 & & & 1 & & & & & 1 & & & & 1 & & & \\
\hline 骨 侵 䰚 & & 1 & 4 & & & & 1 & 3 & & & & & 5 & & \\
\hline 骨久損 & & 2 & 1 & 1 & 10 & & & 1 & 1 & 7 & & & 2 & & 8 \\
\hline 一 致率 & & & $20 / 3$ & & & & & $15 / 1$ & & & & & $14 / 2$ & & \\
\hline
\end{tabular}

表 15 上顎润下壁の所見（断層撮影）

\begin{tabular}{|c|c|c|c|c|c|c|c|c|c|c|}
\hline \multirow{2}{*}{$\backslash^{\mathrm{f}} \backslash^{\mathrm{x}}$} & \multicolumn{2}{|c|}{ 前 } & \multicolumn{3}{|c|}{ 頭 } & \multicolumn{3}{|c|}{ 知 } & \multicolumn{2}{|l|}{ 状 } \\
\hline & IE & $\begin{array}{c}\text { 軽 } \\
\text { 度 } \\
\text { 厚 } \\
\text { 化 }\end{array}$ & $\begin{array}{l}\text { 中 } \\
\text { 等 } \\
\text { 度 } \\
\text { 擪 } \\
\text { 化 }\end{array}$ & $\begin{array}{l}\text { 高 } \\
\text { 度 } \\
\text { 厚 } \\
\text { 化 }\end{array}$ & $\begin{array}{c}\text { 䉼 } \\
\text { 總 } \\
\text { 消 } \\
\text { 失 }\end{array}$ & IF & $\begin{array}{l}\text { 軽 } \\
\text { 度 } \\
\text { 厚 } \\
\text { 化 }\end{array}$ & $\begin{array}{l}\text { 中 } \\
\text { 等 } \\
\text { 度 } \\
\text { 擪 } \\
\text { 化 }\end{array}$ & $\begin{array}{l}\text { 高 } \\
\text { 度 } \\
\text { 厚 } \\
\text { 化 }\end{array}$ & $\begin{array}{l}\text { 断 } \\
\text { 絶 } \\
\text { 消 } \\
\text { 失 }\end{array}$ \\
\hline 正常 & 2 & 5 & 3 & & & & 6 & 1 & & \\
\hline 粘膜侵留 & & & 1 & & & & & 1 & & \\
\hline 骨 侵 貿 & & 3 & 2 & & & & 3 & 3 & 1 & \\
\hline 骨 欠損 & & 2 & & 2 & 10 & & & 1 & & 7 \\
\hline 一致染 & & & $18 / 3$ & & & & & $10 / 2$ & & \\
\hline
\end{tabular}

表 16 上顎洞内壁の所見（単純撮影）

\begin{tabular}{|c|c|c|c|c|c|c|c|c|c|c|}
\hline \multirow{2}{*}{ 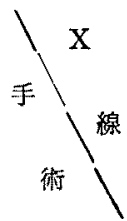 } & \multicolumn{2}{|c|}{ 後 } & 頂 & \multicolumn{2}{|c|}{ 頭 } & \multicolumn{2}{|c|}{ 後 } & 頭 & \multicolumn{2}{|c|}{ 頃 } \\
\hline & $\begin{array}{l}\text { 正 } \\
\text { 常 }\end{array}$ & $\begin{array}{l}\text { 軽 } \\
\text { 度 } \\
\text { 厚 } \\
\text { 化 }\end{array}$ & $\begin{array}{l}\text { 中 } \\
\text { 等 } \\
\text { 度 } \\
\text { 曆 } \\
\text { 化 }\end{array}$ & $\begin{array}{l}\text { 高 } \\
\text { 度 } \\
\text { 厚 } \\
\text { 化 }\end{array}$ & $\begin{array}{l}\text { 断 } \\
\text { 絶 } \\
\text { 消 } \\
\text { 失 }\end{array}$ & 正 & $\begin{array}{l}\text { 俥 } \\
\text { 度 } \\
\text { 曆 } \\
\text { 化 }\end{array}$ & $\begin{array}{l}\text { 中 } \\
\text { 等 } \\
\text { 度 } \\
\text { 曆 } \\
\text { 化 }\end{array}$ & $\begin{array}{l}\text { 高 } \\
\text { 度 } \\
\text { 黥 } \\
\text { 化 }\end{array}$ & 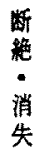 \\
\hline 正 常 & & 1 & & & & & 1 & & & \\
\hline 粘膜侵撉 & & & & & & & & & & \\
\hline 骨 侵 繁 & & & 3 & 2 & & & 1 & 2 & 2 & \\
\hline 骨 久 損 & & & 2 & 9 & 13 & & & 2 & 3 & 19 \\
\hline 一致䇰 & & & 0 & & & & & $24 /$ & & \\
\hline
\end{tabular}


表 17 上買洞内壁の所見(断圈撮影)

\begin{tabular}{|c|c|c|c|c|c|c|c|c|c|c|}
\hline \multirow{5}{*}{ 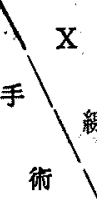 } & \multicolumn{2}{|c|}{ 前 } & \multicolumn{3}{|c|}{ 䫑 } & \multicolumn{3}{|c|}{ 水 } & \multicolumn{2}{|c|}{ 玤 } \\
\hline & 正 & 埾 & 中 & 高 & 断 & 正 & 柽 & 中 & 高 & 断 \\
\hline & & 度 & 等 & 度 & 絶 & & 度 & 等 & 度 & 絶 \\
\hline & & 厚 & 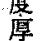 & 曆 & 消 & & 㕌 & $\begin{array}{l}\text { 㷞 } \\
\text {. }\end{array}$ & 曆 & 消 \\
\hline & 常 & 化 & 化 & 化 & 失 & 常 & 化 & 化 & 化 & 失 \\
\hline
\end{tabular}

\begin{tabular}{|c|c|c|c|c|}
\hline 正 常 & 1 & & & \\
\hline 粘膜侵襲 & & & & \\
\hline 贯 侵 嶈 & & 2 & 3 & \\
\hline 骨 欠損 & & 1 & 8 & 15 \\
\hline
\end{tabular}

一致 蜜

\begin{tabular}{|l|l|l|l|l|}
\hline & & & \\
\hline & & & \\
\hline & 1 & 4 & \\
\hline & & 2 & 16 \\
\hline
\end{tabular}

$21 / 23$

表 20 上䫟洞前壁の所見（断磨撮影）

\begin{tabular}{|c|c|c|c|c|c|c|c|c|c|c|}
\hline \multirow[b]{2}{*}{ 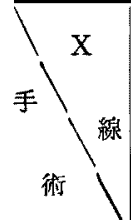 } & \multicolumn{2}{|c|}{ 矢 } & \multicolumn{3}{|c|}{ 状 } & \multicolumn{3}{|c|}{ 本 } & \multicolumn{2}{|c|}{ 平 } \\
\hline & $\begin{array}{l}\text { 正 } \\
\text { 常 }\end{array}$ & $\begin{array}{l}\text { 軽 } \\
\text { 度 } \\
\text { 厚 } \\
\text { 化 }\end{array}$ & $\begin{array}{l}\text { 中 } \\
\text { 䉘 } \\
\text { 度 } \\
\text { 曆 } \\
\text { 化 }\end{array}$ & $\begin{array}{l}\text { 高 } \\
\text { 度 } \\
\text { 愿 } \\
\text { 化 }\end{array}$ & $\begin{array}{l}\text { 断 } \\
\text { 絶 } \\
\text { 消 } \\
\text { 失 }\end{array}$ & 正 & $\begin{array}{l}\text { 整 } \\
\text { 度 } \\
\text { 暦 } \\
\text { 化 }\end{array}$ & $\begin{array}{l}\text { 中 } \\
\text { 等 } \\
\text { 度 } \\
\text { 擪 } \\
\text { 化 }\end{array}$ & $\begin{array}{l}\text { 高 } \\
\text { 度 } \\
\text { 影 } \\
\text { 化 }\end{array}$ & $\begin{array}{l}\text { 断 } \\
\text { 絶 } \\
\text { 消 } \\
\text { 失 }\end{array}$ \\
\hline 正 常 & & & & & & & & & & \\
\hline 粘膜侵薪 & & & & & & & & & & \\
\hline 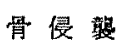 & & 1 & 12 & 1 & & & 1 & 2 & 1 & \\
\hline 骨 欠搰 & & & & & 9 & & 1 & & 1 & 17 \\
\hline
\end{tabular}

一致漂 $23 / 23$

$21 / 23$

表 18 上顎洞外壁の所見 (単純撮影)

\begin{tabular}{|c|c|c|c|c|c|c|c|c|c|c|}
\hline \multirow{2}{*}{$\bigcup_{\text {手 }}^{x}$} & \multicolumn{5}{|c|}{ 後 頭 前 頭 } & \multicolumn{2}{|c|}{ 後 } & 頭 & \multicolumn{2}{|c|}{ 屭 } \\
\hline & 常 & $\begin{array}{l}\text { 跧 } \\
\text { 度 } \\
\text { 厚 } \\
\text { 化 }\end{array}$ & $\begin{array}{l}\text { 中 } \\
\text { 等 } \\
\text { 度 } \\
\text { 曆 } \\
\text { 化 }\end{array}$ & $\begin{array}{l}\text { 高 } \\
\text { 度 } \\
\text { 厚 } \\
\text { 化 }\end{array}$ & $\begin{array}{l}\text { 断 } \\
\text { 絶 } \\
\text { 消 } \\
\text { 失 }\end{array}$ & 正 & $\begin{array}{l}\text { 軽 } \\
\text { 度 } \\
\text { 厚 } \\
\text { 化 }\end{array}$ & $\begin{array}{l}\text { 中 } \\
\text { 等 } \\
\text { 度 } \\
\text { 擪 } \\
\text { 化 }\end{array}$ & $\begin{array}{l}\text { 高 } \\
\text { 度 } \\
\text { 厚 } \\
\text { 化 }\end{array}$ & $\begin{array}{l}\text { 断 } \\
\text { 絶 } \\
\text { 消 } \\
\text { 失 }\end{array}$ \\
\hline 正常 & 1 & 1 & & & & 1 & 1 & & & \\
\hline \multicolumn{11}{|l|}{ 粘膜侵警 } \\
\hline 骨 侵 㜔 & & 4 & 3 & 2 & & & 4 & 3 & 2 & \\
\hline 骨 欠椇 & & 1 & 3 & 2 & 13 & & & 3 & 2 & 14 \\
\hline 一致㻭 & \multicolumn{5}{|c|}{$23 / 30$} & \multicolumn{5}{|c|}{$24 / 30$} \\
\hline
\end{tabular}

\begin{tabular}{|c|c|c|c|c|c|c|c|c|c|c|}
\hline \multirow[b]{2}{*}{$\begin{array}{l}x \\
\text { 手 } \\
\end{array}$} & \multicolumn{2}{|c|}{ 軸 } & \multicolumn{3}{|c|}{ 位 } & \multicolumn{5}{|c|}{ レーゼ氏法 } \\
\hline & IE & $\begin{array}{l}\text { 柽 } \\
\text { 度 } \\
\text { 憬 } \\
\text { 化 }\end{array}$ & $\begin{array}{l}\text { 中 } \\
\text { 等 } \\
\text { 度 } \\
\text { 厴 } \\
\text { 化 }\end{array}$ & $\begin{array}{l}\text { 高 } \\
\text { 度 } \\
\text { 厚 } \\
\text { 化 }\end{array}$ & $\begin{array}{l}\text { 断 } \\
\text { 絶 } \\
\text { 消 } \\
\text { 失 }\end{array}$ & 常 & $\begin{array}{l}\text { 軽 } \\
\text { 度 } \\
\text { 曆 } \\
\text { 化 }\end{array}$ & $\begin{array}{l}\text { 中 } \\
\text { 等 } \\
\text { 度 } \\
\text { 檿 } \\
\text { 华 }\end{array}$ & $\begin{array}{l}\text { 高 } \\
\text { 度 } \\
\text { 厚 } \\
\text { 化 }\end{array}$ & $\begin{array}{l}\text { 断 } \\
\text { 絶 } \\
\text { 消 } \\
\text { 失 }\end{array}$ \\
\hline \multicolumn{11}{|l|}{ 正 常 } \\
\hline \multicolumn{11}{|l|}{ 粘膜侵朣 } \\
\hline 骨 侵 唼 & & 2 & 4 & 2 & & & & 3 & 3 & 1 \\
\hline 骨 欠損 & & & 3 & 6 & 9 & & & 1 & 1 & 14 \\
\hline 一致受 & & & $1 / 2$ & & & & & 20 & & \\
\hline
\end{tabular}

表 19 上顎洞外壁の所見（断層撮影）

\begin{tabular}{|c|c|c|c|c|c|c|c|c|c|c|}
\hline \multirow{2}{*}{$\left.\int^{x}\right|^{x}$} & \multicolumn{2}{|c|}{ 前 } & \multicolumn{3}{|c|}{ 頭 } & \multicolumn{3}{|c|}{ 水 } & \multicolumn{2}{|c|}{ 平 } \\
\hline & 正 & $\begin{array}{l}\text { 柽 } \\
\text { 度 } \\
\text { 厚 } \\
\text { 化 }\end{array}$ & $\begin{array}{l}\text { 中 } \\
\text { 等 } \\
\text { 度 } \\
\text { 影 } \\
\text { 化 }\end{array}$ & $\begin{array}{l}\text { 滈 } \\
\text { 度 } \\
\text { 厚 } \\
\text { 化 }\end{array}$ & $\begin{array}{c}\text { 断 } \\
\text { 絶 } \\
\text { 消 } \\
\text { 失 }\end{array}$ & 常 & $\begin{array}{l}\text { 軽 } \\
\text { 度 } \\
\text { 曆 } \\
\text { 化 }\end{array}$ & $\begin{array}{l}\text { 中 } \\
\text { 等 } \\
\text { 度 } \\
\text { 願 } \\
\text { 化 }\end{array}$ & $\begin{array}{l}\text { 宫 } \\
\text { 度 } \\
\text { 厚 } \\
\text { 化 }\end{array}$ & $\begin{array}{l}\text { 断 } \\
\text { 絶 } \\
\text { 消 } \\
\text { 失 }\end{array}$ \\
\hline 正 常 & & 1 & 1 & & & 1 & 1 & & & \\
\hline \multicolumn{11}{|l|}{ 絬瞙侵警 } \\
\hline 骨 侵 蟹 & & 1 & 5 & 3 & & & 1 & 2 & & \\
\hline 盈久搷 & & & 3 & & & & & & 1 & 7 \\
\hline 一致率 & \multicolumn{5}{|c|}{$25 / 30$} & \multicolumn{5}{|c|}{$21 / 23$} \\
\hline
\end{tabular}

表 22 上䫈洞後壁の所見（断圈撮影）

\begin{tabular}{|c|c|c|c|c|c|c|c|c|c|c|}
\hline \multirow{2}{*}{$\int_{\text {街 }}^{x}$} & \multicolumn{2}{|c|}{ 矢 } & \multicolumn{3}{|c|}{ 状 } & \multicolumn{3}{|c|}{ 水 } & \multicolumn{2}{|c|}{ 平 } \\
\hline & $\begin{array}{l}\text { 正 } \\
\text { 常 }\end{array}$ & $\begin{array}{l}\text { 輟 } \\
\text { 度 } \\
\text { 厚 } \\
\text { 化 }\end{array}$ & $\begin{array}{l}\text { 中 } \\
\text { 等 } \\
\text { 度 } \\
\text { 愿 } \\
\text { 化 }\end{array}$ & $\begin{array}{l}\text { 高 } \\
\text { 度 } \\
\text { 厚 } \\
\text { 化 }\end{array}$ & $\begin{array}{l}\text { 断 } \\
\text { 絶 } \\
\text { 消 } \\
\text { 失 }\end{array}$ & 正 & $\begin{array}{l}\text { 軽 } \\
\text { 度 } \\
\text { 嬮 } \\
\text { 化 }\end{array}$ & $\begin{array}{l}\text { 中 } \\
\text { 等 } \\
\text { 度 } \\
\text { 曆 } \\
\text { 化 }\end{array}$ & $\begin{array}{l}\text { 高 } \\
\text { 度 } \\
\text { 厚 } \\
\text { 化 }\end{array}$ & $\begin{array}{l}\text { 断 } \\
\text { 絶 } \\
\text { 消 } \\
\text { 失 }\end{array}$ \\
\hline \multicolumn{11}{|l|}{ 正 常 } \\
\hline \multicolumn{11}{|l|}{ 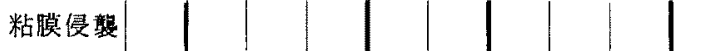 } \\
\hline 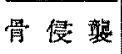 & & & 7 & 1 & & & 2 & 4 & 1 & \\
\hline 骨 久損 & & & 2 & 1 & 12 & & & & & 16 \\
\hline 一致率 & & & $20 / 2$ & & & & & $23 / 2$ & & \\
\hline
\end{tabular}


表 23 眼简下孔と上壁との関係

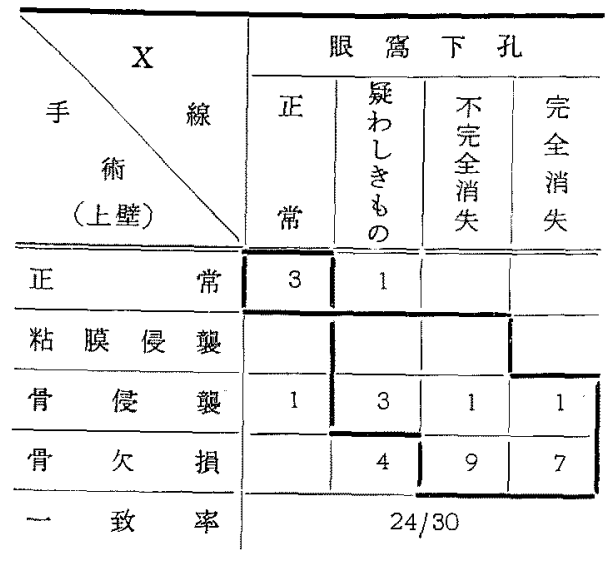

b) 就形 洞

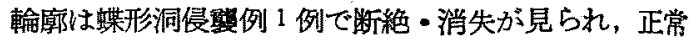
例 29 例中 26 例分軽度乃挃中等度厚化を示し，3 例で X 線上も正常を示すに過ぎない。

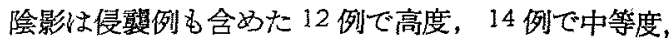
4 例で軽度增強を示し，全例に陰影增強が認められる。

c) 翼状害起

翼状突起侵㜔例 5 例中 3 例で形態の変形が見られ，2 例は正常で，正常例 25 例は全て形態も正常である。

侵翼例 5 例中 2 例で陰影淡化が見られ，3例は中等度

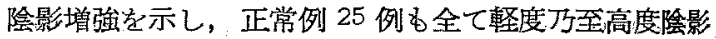
增強を示す。

d) 翼状突起陰影々上顎洞後壁との関係（表 30）

後壁骨侵留例 10 例中 3 例が翼状突起陰影軽度增強を，

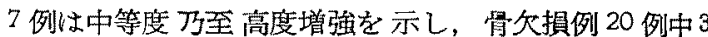

表 24 紙状板と節骨蜂隼との関䌽

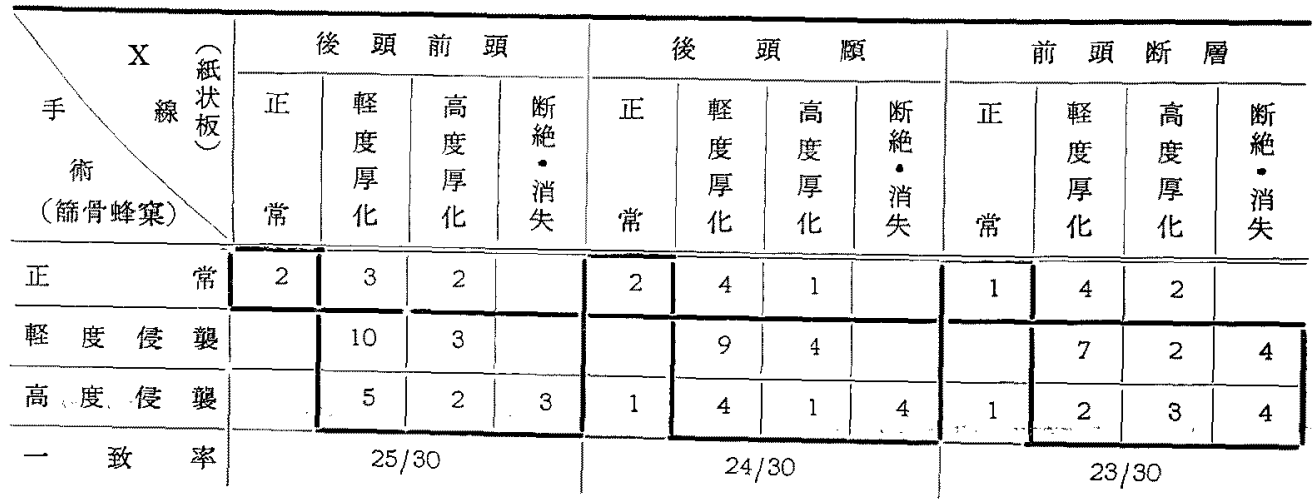

表 25 節骨蜂窂ととの隔壁との関係

\begin{tabular}{|c|c|c|c|c|c|c|c|}
\hline \multirow{2}{*}{ 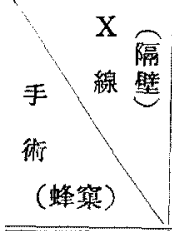 } & 後 & 頭 & 前 & 頭 & 前 & 頭 断 & 層 \\
\hline & 常 & 化 & $t$ & $\begin{array}{l}\text { 断 } \\
\text { 絰 } \\
\text { 消 } \\
\text { 失 }\end{array}$ & 正 & 擪 & $\begin{array}{c}\text { 断 } \\
\text { 緦 } \\
\text { 消 } \\
\text { 失 }\end{array}$ \\
\hline 正常 & 7 & & & & 6 & 1 & \\
\hline 軽度侵鼔 & 1 & & & 12 & & & 13 \\
\hline 高度侵繁 & & & 1 & 9 & & & 10 \\
\hline 一致 率 & & 291 & 30 & & & $29 / 30$ & \\
\hline
\end{tabular}

䒾 26 梨状孔緣の所見

\begin{tabular}{|c|c|c|c|c|c|}
\hline $\mathrm{X}$ & & 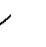 & 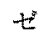 & $i$ & \\
\hline 術 & IF & $\begin{array}{l}\text { 軽 } \\
\text { 度 } \\
\text { 厚 } \\
\text { 化 }\end{array}$ & $\begin{array}{l}\text { 中 } \\
\text { 等 } \\
\text { 度 } \\
\text { 㕌 } \\
\text { 化 }\end{array}$ & $\begin{array}{l}\text { 高 } \\
\text { 度 } \\
\text { 昉 } \\
\text { 化 }\end{array}$ & $\begin{array}{l}\text { 䉼 } \\
\text { 絶 } \\
\text { 消 } \\
\text { 失 }\end{array}$ \\
\hline 正常 & & 1 & & & \\
\hline 粘 膜 侵 獎 & 1 & & 4 & 1 & \\
\hline 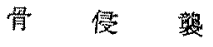 & & 1 & 3 & 2 & \\
\hline 骨 次 摜 & & & & & 10 \\
\hline 一 致 率 & & & $21 / 23$ & & \\
\hline
\end{tabular}


表 27 下番介骨力所見

\begin{tabular}{|c|c|c|c|c|c|c|}
\hline 8 & 後 & 頭 & 頭 & 前 & 頭 料 & 㬝 \\
\hline 手 線 & $\begin{array}{l}\text { 正 } \\
\text { 常 }\end{array}$ & $\begin{array}{l}\text { 骨 } \\
\text { 常 } \\
\text { 端 } \\
\text { 消 } \\
\text { 失 }\end{array}$ & $\begin{array}{l}\text { 骨 } \\
\text { 消 } \\
\text { 失 }\end{array}$ & $\begin{array}{l}\text { 正 } \\
\text { 裳 }\end{array}$ & $\begin{array}{l}\text { 骨 } \\
\text { 竞 } \\
\text { 端 } \\
\text { 失 }\end{array}$ & $\begin{array}{l}\text { 骨 } \\
\text { 消 } \\
\text { 失 }\end{array}$ \\
\hline 正常 & 5 & & & 5 & & \\
\hline 軟部侵㙰 & 4 & 1 & & 4 & 1 & \\
\hline 骨 侵 弉 & & & 12 & 1 & & 11 \\
\hline 骨 崩 摆 & & 2 & 6 & & & 8 \\
\hline 一致 婆 & & $27 / 3$ & & & $28 / 30$ & \\
\hline
\end{tabular}

表 28 中畄介骨の所見

\begin{tabular}{|c|c|c|c|c|c|c|}
\hline \multirow{2}{*}{ 手 } & 後 & 頑 & 頭 & 前 & 頭 & 層 \\
\hline & 常 & $\begin{array}{l}\text { 骨 } \\
\text { 端 } \\
\text { 消 } \\
\text { 失 }\end{array}$ & $\begin{array}{l}\text { 骨 } \\
\text { 消 } \\
\text { 失 }\end{array}$ & 正 & $\begin{array}{l}\text { 骨 } \\
\text { 章 } \\
\text { 端 } \\
\text { 失 }\end{array}$ & $\begin{array}{l}\text { 骨 } \\
\text { 消 } \\
\text { 失 }\end{array}$ \\
\hline 正 & 6 & 1 & & 7 & & \\
\hline 軟 部 侵 熟 & 5 & 5 & & 7 & 3 & \\
\hline 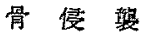 & & 2 & 5 & 1 & & 6 \\
\hline 骨 崩 壊 & & & 6 & & & 6 \\
\hline 一致 率 & & $24 / 3$ & & & $26 / 3$ & \\
\hline
\end{tabular}

表 29 奥底骨の所見

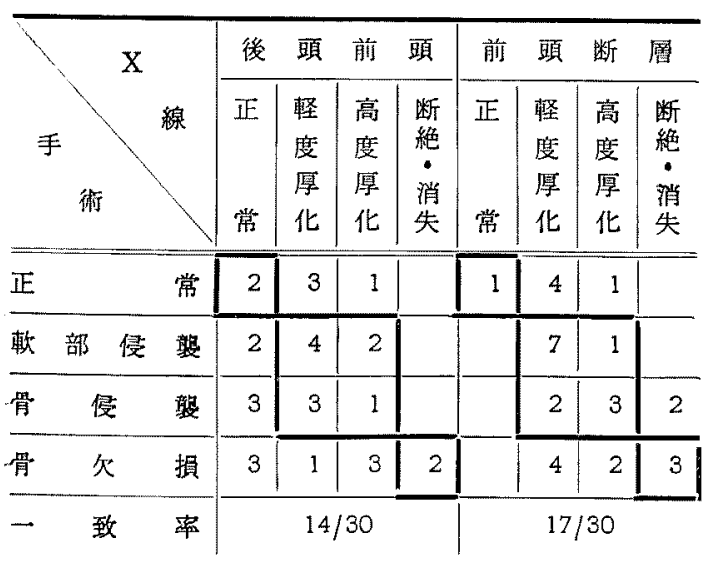

例が軽度增強を，15 例が中等度乃至高度增強を示すが，

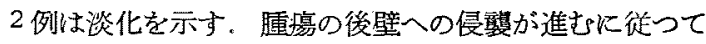
翼状乫起陰影所見子著明となる。

e) 煩骨㓌影 (表31)

正常例 4 例中 2 例が X 線上も正常で，他の 2 例は軽 度增強を，周辺骨侵憩例 6 例全てが軽度乃至中等度增強 を，頓骨㻏糸例 9 例中 1 例が軽度增強を，8例が中等度 乃至高度增強を示し，煩骨欠損例 11 例中 6 例が淡化を 示主が，5例は中等度乃至高度增強を示す一致率は 23 130である。

4) Rhese 氏法撮影 (表 5)

a) 上顎洞陰影

不規則性 3 が 1 例， 2 が 6 例， 1 が 14 例， 0 が 2 例 で，大多数の例が不規則性を示す。

b）上顎洞上壁 (表 12)

正常例 2 例いずれる軽度乃至中等度厚化を，骨侵顠例 5 例全てが中等度 乃至 高度厚化を示し，骨欠損例 16 例 中 12 例は断絶・消失を示すが，4 例は中等度乃至高度 暻化を示す一致率は17/23で，後頭前頭撮影と殆ど同 じである。

c）上䫁洞下壁（表 14）

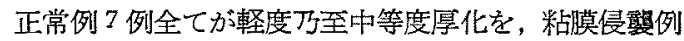
1 例が軽度厚化を，骨侵䰚例 5 例全てが中等度厚化を示 乙, 骨欠損例 10 例中 8 例は断絶・消失を示寸が， 2 例 は中等度厚化を示す. 一致率は $14 / 23$ で, 後頭前頭撮影 と殆ど同じである。

d) 上罰洞外後壁 (表 21)

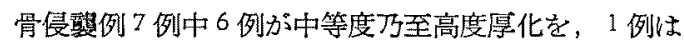
断絶・消失を，骨欠椇例 16 例中 14 例は断絶・消失を示 すが，2 例は中等度乃至高度厚化を示す一致率は201 23 で，軸位撮影よりかなり良い。

e) 梨状孔粶（表 26）

正常例 1 例 等度乃至高度厚化を示寸が，1 例は正常で，骨侵翼例 6 例全てが軽度乃至高度厚化を示し，骨欠損例 10 例全て が游絶・消失を示す一致率は $21 / 23$ と高率を示主。

f）視神絽孔と蝶形洞之の関係

蝶形洞侵㛄例 1 例が $\mathrm{X}$ 線上視神経孔輪嫄の断絶・消 失を示し, 正常例 22 例中 13 例は正常であるが，9例は 軽度乃至中等度愿化を示す 雨所見間に㴎からりの関連 性がある。

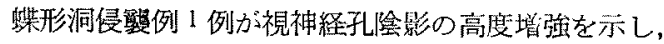
正常例 22 例中 8 例灶正常であるが，14 例灿柽度つ至中 
等度厚化を示す。

g) 視神経孔と上類洞上壁との関係（表 32）

上颚洞上壁正常例 2 例中 1 例か $\mathrm{X}$ 線上む視神経孔輪

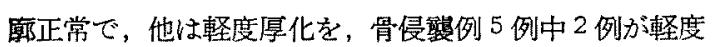
乃至中等度厚化を示すが， 3 例は正常である. 骨欠損例 16 例中 1 例が断絶・消失を 6 例が軽度厚化を示すが，9 例は正常である。両所見間には多少の関運性がある。

上顎洞上壁正常例 2 例中 1 例が $\mathrm{X}$ 線上も視神経孔陰 影正常で，他は軽度增強を，骨侵献例 5 例中 3 例が軽度 增強を示すが，2例は正常で，骨欠損例16 例中 1 例が 淡化を，10 例が軽度乃至中等度增強を示すが，5 例は正 常である.

C) 断層撮影々手術所見との比較

表中斜線の部は所属断層面儿存在しない事を示す 又，四面中最も強い变化をるつてその部位の所見として 手術所見と比較检討した。
1) 前頭断層撮影 (表 6)

a) 上颚洞陰影

不規則性 3 が 5 例, 2 か゚ 17 例, 1 か 8 例で, 全例が不 規則性を示し，単純撮影と比べ著明な不規則性を示す

b) 上罰洞上壁（表 13)

正常例 4 例全てが： X 線上軽度乃至中等度厚化を，骨 侵楽例 6 例全てが軽度乃至中等度愿化を示し，骨欠損例 20 例中 16 例が断絶・消失を示すが，4 例は軽度乃至高 度厚化を示す一致率は $22 / 30$ で, 後頭前頭撮影上りか なり良い。

c）上顎洞下壁 (表 15)

正常例 10 例中 2 例が $X$ 線上も正常で，8 例は軽度乃 至中等度厚化を，粘膜侵嶈例 1 例が中等度厚化を，骨侵 留例 5 例全てが 軽度乃至 中等度厚化を示し，骨久損例 14 例中 10 例が断絶・消失を示すが，4例は軽度あるい は高度厚化を示す 一致率は18/30で, 後頭前頭撮影よ

表 30 翼状突起隆影と後壁との関係

\begin{tabular}{|c|c|c|c|c|c|c|c|c|c|c|c|c|c|c|c|}
\hline \multirow{2}{*}{ 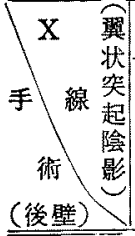 } & \multicolumn{3}{|c|}{ 軸 } & \multicolumn{2}{|l|}{ 位 } & \multicolumn{5}{|c|}{ 前頭断 層 } & \multicolumn{5}{|c|}{ 矢 状 断 皇 } \\
\hline & 常 & $\begin{array}{l}\text { 軽 } \\
\text { 度 } \\
\text { 增 } \\
\text { 強 }\end{array}$ & $\begin{array}{l}\text { 中 } \\
\text { 等 } \\
\text { 度 } \\
\text { 增 } \\
\text { 強 }\end{array}$ & $\begin{array}{l}\text { 高 } \\
\text { 度 } \\
\text { 增 } \\
\text { 强 }\end{array}$ & 淡 & 常 & $\begin{array}{l}\text { 軽 } \\
\text { 度 } \\
\text { 增 } \\
\text { 強 }\end{array}$ & $\begin{array}{l}\text { 中 } \\
\text { 等 } \\
\text { 度 } \\
\text { 增 } \\
\text { 強 }\end{array}$ & $\begin{array}{l}\text { 高 } \\
\text { 度 } \\
\text { 增 } \\
\text { 强 }\end{array}$ & $\begin{array}{l}\text { 淡 } \\
\text { 化 }\end{array}$ & $\begin{array}{l}\text { 正 } \\
\text { 㦂 }\end{array}$ & $\begin{array}{l}\text { 軽 } \\
\text { 度 } \\
\text { 增 } \\
\text { 強 }\end{array}$ & $\begin{array}{l}\text { 中 } \\
\text { 等 } \\
\text { 度 } \\
\text { 增 } \\
\text { 强 }\end{array}$ & $\begin{array}{l}\text { 高 } \\
\text { 度 } \\
\text { 增 } \\
\text { 強 }\end{array}$ & $\begin{array}{l}\text { 淡 } \\
\text { 化 }\end{array}$ \\
\hline 常 & & & & & & & & & & & & & & & \\
\hline 粘膜侵裂 & & & & & & & & & & & & & & & \\
\hline 骨 侵 面 & & 3 & 5 & 2 & & & 2 & 5 & 3 & & & 4 & 2 & 1 & \\
\hline 骨 久損 & & 3 & 12 & 3 & 2 & & 5 & 11 & 3 & 1 & & 5 & 8 & 3 & \\
\hline
\end{tabular}

衣 31 頖骨隍影の所見

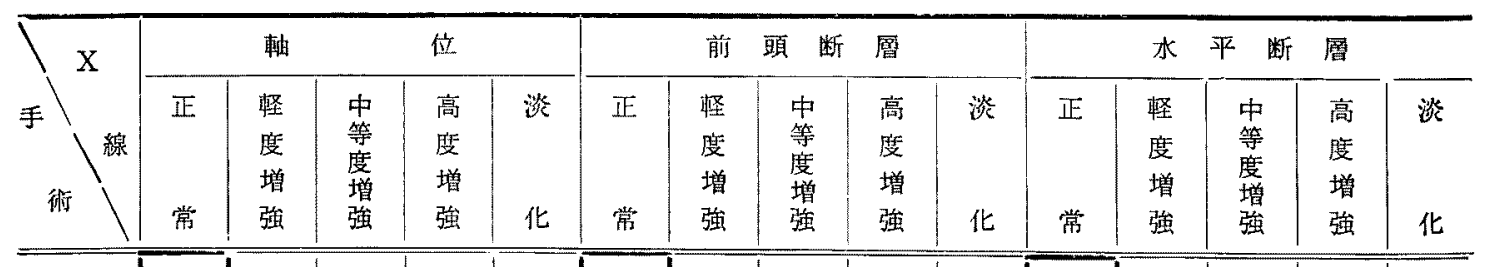

\begin{tabular}{|c|c|c|c|c|c|c|c|c|c|c|c|c|c|c|}
\hline 正常 & 2 & 2 & & & & 3 & 1 & & & & 2 & & & \\
\hline 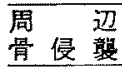 & & 2 & 4 & & & & 2 & 4 & & & 1 & 5 & & \\
\hline 㛲骨侵襲 & & 1 & 5 & 3 & & & 1 & 6 & & 2 & & 5 & & \\
\hline 類骨久損 & & & 4 & 1 & 6 & & & & 1 & 10 & & 2 & I & 7 \\
\hline 一致率 & & & $3 / 3$ & & & & & $5 / 30$ & & & & $8 / 2$ & & \\
\hline
\end{tabular}


りや项し,

\section{d）上顠洞内壁（表 17)}

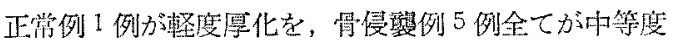

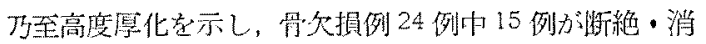

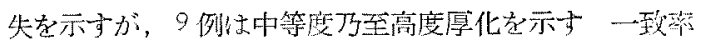

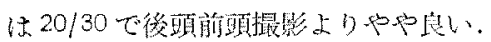

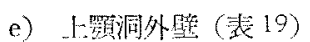

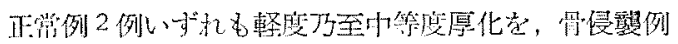

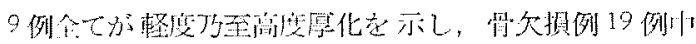

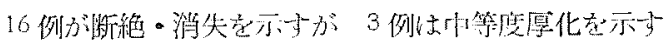

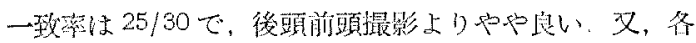

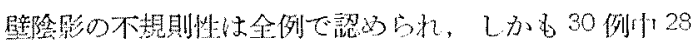
侧で 2 以上の不挸則性を示す

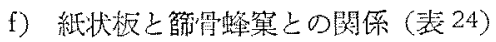

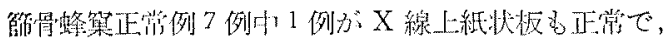

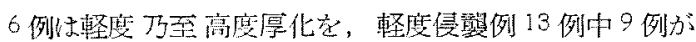

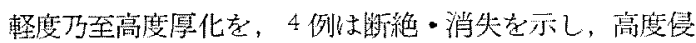

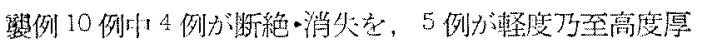

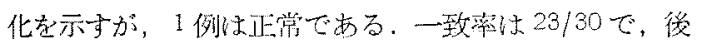

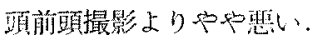

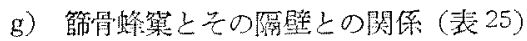

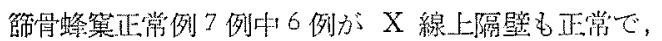

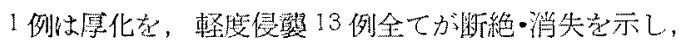

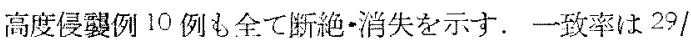

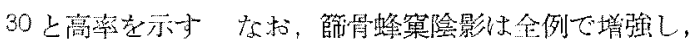

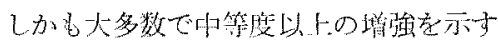

h) 橴 形 洞

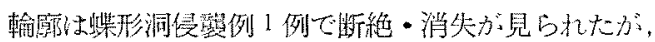

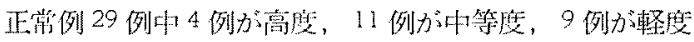
厚化を示し，嚾か５例区正常所見が見５机た沉過ぎな w.

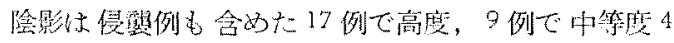

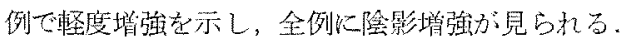

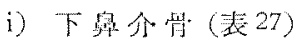

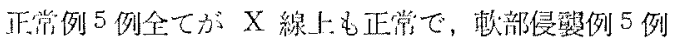

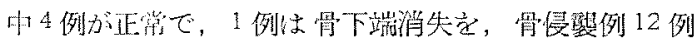

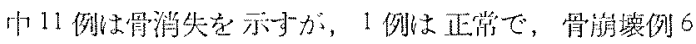

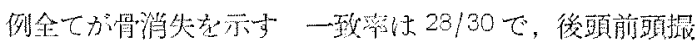

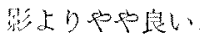

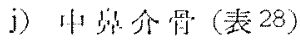

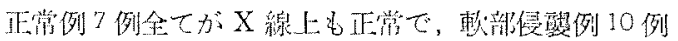

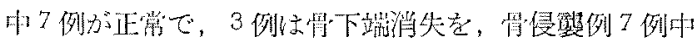

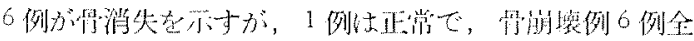

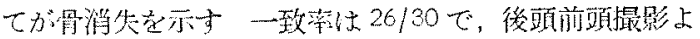
门队户舆以

k) 率 底 骨(表29)

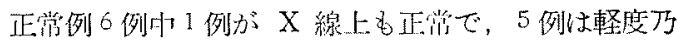
至高度厚化を，軟部侵鼠例 8 例全てが軽度纴至高度厚化

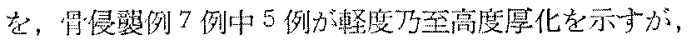

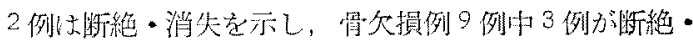

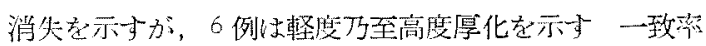

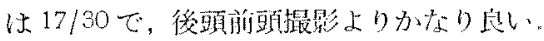

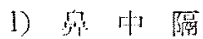

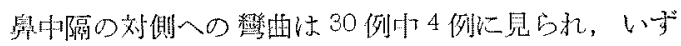

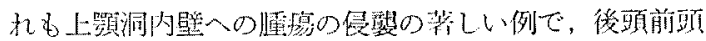
撮影と同じ結果を示す

m) 翼炏突起

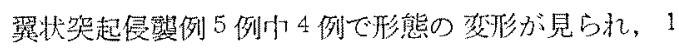
例は正常で，正常例 25 例は主て形態も正常である。軸

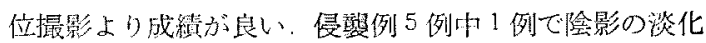

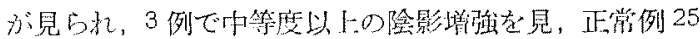
例も全て陰影の增强を示し，しか子18例で中等度以上 の增強を示可

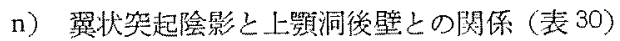

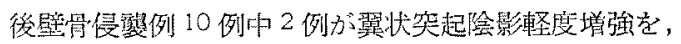

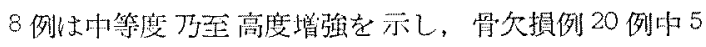
例が軽度增㤝を，14例が中等度乃至高度增强を示与が，

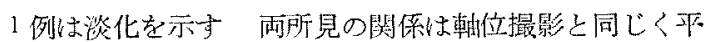
行马右

○) 頓畄隍影（表31)

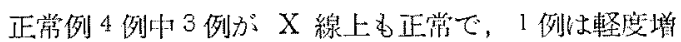

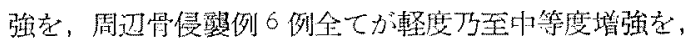

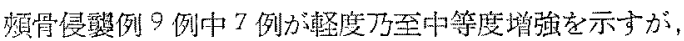

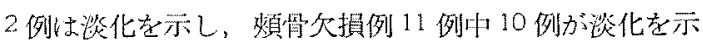

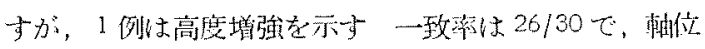
撮影よりか子り良い

2) 与状断圈撮影 (整7)

第 4 面（健側）を対照として第2 而 (热側) の所见を 検討した。

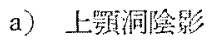

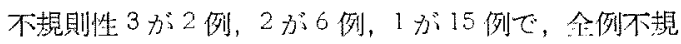
則性を示す

b）上颚洞上壁（表 13)

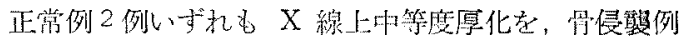
9 例全てが軽度乃至高度厚化を示し，带次賣例 12 例全

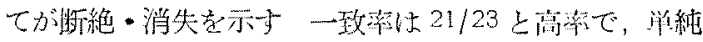


各撮影・前頭断㬝撮影より著しく良い，

c) 上穎洞下壁 (表 15)

正常例 7 例全てが軽度乃至中等度愿化を，粘膜侵襲例 1 例が中等度厚化を，骨侵警例 7 例全てが軽度乃至高度 厚化を示し，骨欠損例 8 例中 7 例が断絶・消失を示す が，1 例は中等度厚化を示す，一致率は $15 / 23 て ゙ ，$ 後頭 前頭撮影と殆ど同じである。

d）上顎洞前壁 (表 20)

骨侵㢣例 14 例全てが軽度 万至高度厚化を示し，骨尔 損例 9 例全てが断絶・消失を示す 一致彎は $23 / 23$ の 100\%である.

e）上顎洞後壁（表 22）

骨侵裂例 8 例全てが中等度乃至高度厚化を示し，骨欠 損例 15 例中 12 例が断絶・消失を示すが，3 例は中等度 乃至高度厚化を示す 一致率は20/23で, Rhese 氏法 と同じである. 又各壁陰影の不規則性は 23 例中 20 例で 見られる。

f) 翼状突起

翼状突起侵翼例 2 例いずれも形態の变形を示し，正常 例 21 例は全て形態も正常である。

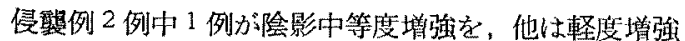
を示し，正常例 21 例も全て除影の增強示し，17 例で 軽度乃至中等度增強を示す

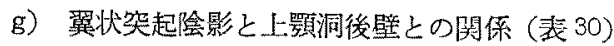

後壁骨唚熟例 7 例中 4 例 3例は中等度乃至高度增強を示し，䯚欠損例 16 例中 5 例が軽度增強を示し，11 例は中等度 乃至高度增強を示 す. 手術, $\mathrm{X}$ 缐両所見の関倸は他撮影と同じく平行す る.

3）水平断層撮影 (表 8)

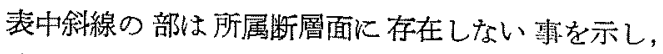

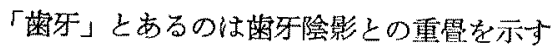

\section{a) 上顎洞陰影}

不規則性 3 が 4 例， 2 が 9 例， 1 が9例，○が1例で， 23 例中 22 例が不規則性を示し，単純撮影と比べがり 著明な不規則性を示寸。

b）上顎洞内壁（表 17)

骨侵警例 5 例全てが X 線上中等度顶至高度厚化を示 乙，骨欠損例 18 例中 16 例䛧絶・消失を示すが，2 例 は高度厚化を示す一致率は21/23で，他撮影上り著明 熄い。

c）上顎洞外壁（表 19）

正常例 2 例中 1 例が X 線上子正常で，他の 1 例话軽
度厚化を，骨侵繁例 3 例全てが軽度つ至中等度厚化を示 し，骨欠損例 18 例中 17 例が断絶・消失を示すが，1例

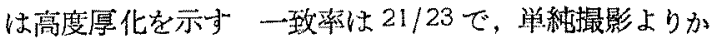
なり良い。

d）上顎洞前壁（表 20）

骨侵㜥例 4 例全てが軽度乃至高度厚化を示し，骨欠損 例 19 例中 17 例が断絶・消失を示すが，2 例は軽度ある いは高度厚化を示す一致率は $21 / 23$ の高率たが，矢状 断㐿撮影よりやや悪い。

e）上顎洞後壁（表 22）

骨侵敦例 7 例全てが軽度乃至高度厚化を示し，骨欠損 例 16 例は全て断絶·消失を示す一致率は 23/23の100 \%で，矢状断層撮影よりやや良い，又，各壁陰影の不 規則性は 23 例中 22 例で見られ，いずれも 2 以上の不規 則性を示守

f) 煩骨陰影 (表 31)

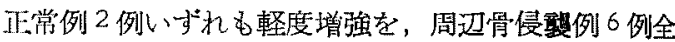
てが軽度乃至中等度增強を，煩骨侵侗例 5 例全てが中等 度增強を示し，煩骨欠損例 10 例中 7 例が淡化を示すが， 3 例生中等度乃至高度增强を示す。一致率は 18/23で， 軸位撮影と殆ど同じである。

D) 沪道造影撮影と手術所見との比較（表9）

琵中斜線の部は下鼻道への造影到の流下は見られる が，該部に造影剂の存在しない事を示し「「閉塞」とあ るのは舆涙管の閉塞を示す

1) 泛嘎輪敦 (表 33)

正面撮影では正常例 9 例中 5 例が平滑で，4 例は波形 を，粘膜侵襲例 7 例中 5 例が平滑で，2 例は波形を，骨 侵熋例 4 例中 2 例か゚平滑で，他の 2 例は波形を示し，骨 崩壊例 11 例中 5 例が平滑で，6例は波形を示す.

表 32 視神経孔と上壁との関俰 (Rhese 氏法)

\begin{tabular}{|c|c|c|c|c|c|c|c|c|c|c|}
\hline \multirow{2}{*}{ 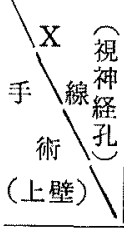 } & \multicolumn{2}{|c|}{ 㭗 } & \multicolumn{3}{|c|}{ 㽷 } & \multicolumn{3}{|c|}{ 陰 } & \multicolumn{2}{|c|}{ 影 } \\
\hline & 正 & $\begin{array}{l}\text { 桯 } \\
\text { 度 } \\
\text { 厚 } \\
\text { 化 }\end{array}$ & $\begin{array}{l}\text { 中 } \\
\text { 等 } \\
\text { 䅎 } \\
\text { 化 } \\
\end{array}$ & $\begin{array}{l}\text { 高 } \\
\text { 度 } \\
\text { 厚 } \\
\text { 化 }\end{array}$ & $\begin{array}{l}\text { 断 } \\
\text { 紿 } \\
\text { 消 } \\
\text { 失 }\end{array}$ & 常 & $\begin{array}{l}\text { 慗 } \\
\text { 度 } \\
\text { 增 } \\
\text { 強 }\end{array}$ & $\begin{array}{l}\text { 中 } \\
\text { 等 } \\
\text { 臀 } \\
\text { 增 } \\
\text { 强 }\end{array}$ & $\begin{array}{l}\text { 高 } \\
\text { 度 } \\
\text { 增 } \\
\text { 強 }\end{array}$ & \\
\hline 常 & 1 & 1 & & & & 1 & 1 & & & \\
\hline 炶膜侵惖 & & & & & & & & & & \\
\hline 骨侵喰 & 3 & 1 & 1 & & & 2 & 3 & & & \\
\hline - 久損 & 9 & 3 & 3 & & 1 & 5 & 7 & 3 & & 1 \\
\hline
\end{tabular}


表 36 鼠源管㹟寉の所見

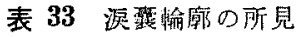

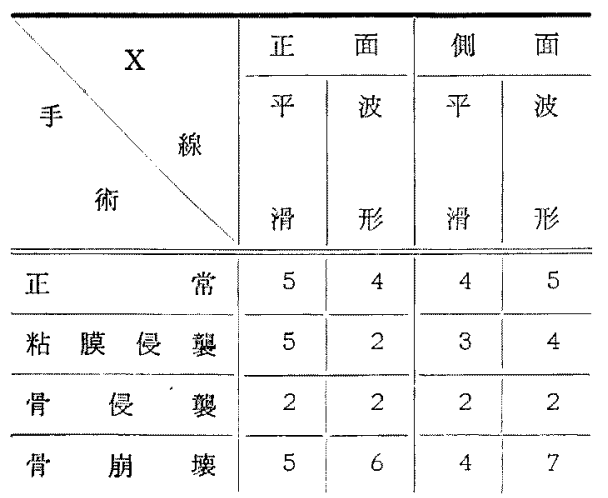

表 34 渗裂搪張の所見

\begin{tabular}{|c|c|c|c|c|c|c|c|c|}
\hline \multirow[b]{2}{*}{ 術 } & \multicolumn{3}{|l|}{ 正 } & 面 & \multicolumn{3}{|l|}{ 側 } & 面 \\
\hline & 正 & $\begin{array}{l}\text { 柽 } \\
\text { 度 } \\
\text { 拡 } \\
\text { 張 }\end{array}$ & $\begin{array}{l}\text { 中 } \\
\text { 等 } \\
\text { 慰 } \\
\text { 䓛 } \\
\text { 涱 }\end{array}$ & $\begin{array}{l}\text { 高 } \\
\text { 度 } \\
\text { 抾 } \\
\text { 張 }\end{array}$ & $\begin{array}{l}\text { 正 } \\
\text { 常 }\end{array}$ & $\begin{array}{l}\text { 怪 } \\
\text { 度 } \\
\text { 拡 } \\
\text { 張 }\end{array}$ & $\begin{array}{l}\text { 中 } \\
\text { 中䈝 } \\
\text { 度 } \\
\text { 执 } \\
\text { 涱 }\end{array}$ & $\begin{array}{l}\text { 高 } \\
\text { 度 } \\
\text { 拡 } \\
\text { 㖘 }\end{array}$ \\
\hline 常 & 8 & & 1 & & 8 & & 1 & \\
\hline 粘 膜 侵 站 & 3 & 2 & 1 & 1 & 4 & 1 & 2 & \\
\hline 侵擎 & I & 3 & & & 4 & & & \\
\hline 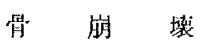 & 3 & 1 & 1 & 5 & 6 & & 3 & 1 \\
\hline
\end{tabular}

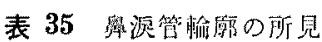

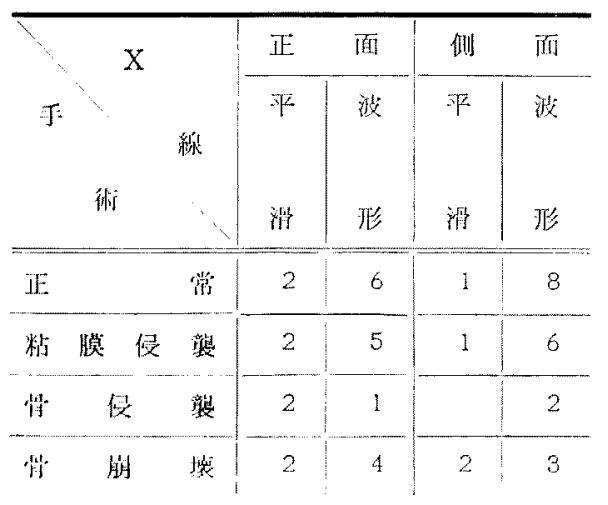

\section{側面撮影でも殆ど類似の結果を示一}

2) 淈露抬張（表34）

拡張の基潐は本村に做い，正面像では $3 \sim 4 \mathrm{~mm} ， 4 \sim$ $5 \mathrm{~mm}, 5 \mathrm{~mm}$ 以上を，側面像で结 $5.5 \sim 6.5 \mathrm{~mm}, 6.5 \mathrm{~mm}$ $\sim 7.5 \mathrm{~mm}, 7.5 \mathrm{~mm}$ 以上を夫夕軽度, 中等度, 高度抬張 とし，夫々（十，（H)，(卅)で裴した。

正面撮影では正常例 9 例中 8 例が正常で，1 例は中等

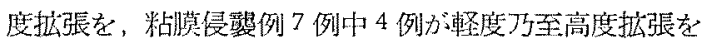

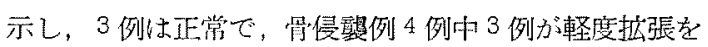
示し，1例は正労で，骨崩壤例 10 例中 2 例が軽度乃至 中等度， 5 例が高度㹡張を示し，3例が正常で，病贺の

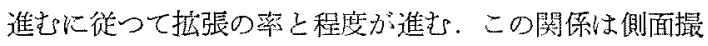
影でも同じである。

3) 鼻涙管輸廓 (表 35)

正面撮影では正常例8例中 2 例が平滑で，6例は波形

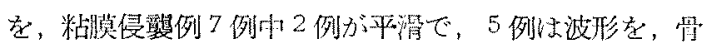

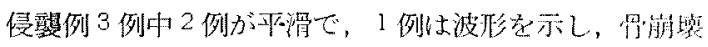

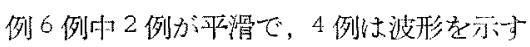

側面撮影でも殆ど類似の糿果走示与

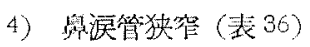

狭窄の基蕉は本村に做い，正面候で 1.2 1.0 mm, $1.0 \sim 0.8 \mathrm{~mm}, 0.8 \mathrm{~mm}$ 以下を, 僛面像ては $2.0 \sim 1.5 \mathrm{~mm}$, $1.5 \sim 1.0 \mathrm{~mm}, 1.0 \mathrm{~mm}$ 以下を夫々軽度，中等度，高度狭 啃上し，夫々（十，（H）（H）で表わした。

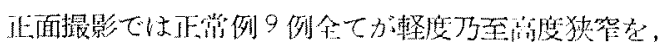

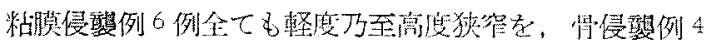

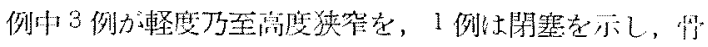

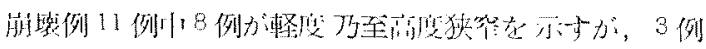


表 37 鲎淡管「モ」影淡化の所見

\begin{tabular}{|c|c|c|c|c|c|c|}
\hline $\mathrm{X}$ & 正: & & 面 & 側 & & 面 \\
\hline fa & 正 & $\begin{array}{l}\text { 軽 } \\
\text { 度 } \\
\text { 淡 } \\
\text { 化 }\end{array}$ & $\begin{array}{l}\text { 高 } \\
\text { 度 } \\
\text { 淡 } \\
\text { 化 }\end{array}$ & 正 & $\begin{array}{l}\text { 埾 } \\
\text { 度 } \\
\text { 淡 } \\
\text { 化 }\end{array}$ & $\begin{array}{l}\text { 高 } \\
\text { 度 } \\
\text { 淡 } \\
\text { 化 }\end{array}$ \\
\hline 正常 & & 8 & & 1 & 6 & 2 \\
\hline 粘膜侵䪭 & 3 & 3 & 1 & 2 & 4 & 1 \\
\hline 骨 侵 晹 & 2 & 1 & & 1 & 1 & \\
\hline 兴 崩 壊 & & 4 & 2 & & 4 & 1 \\
\hline
\end{tabular}

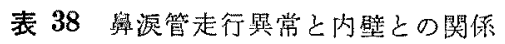

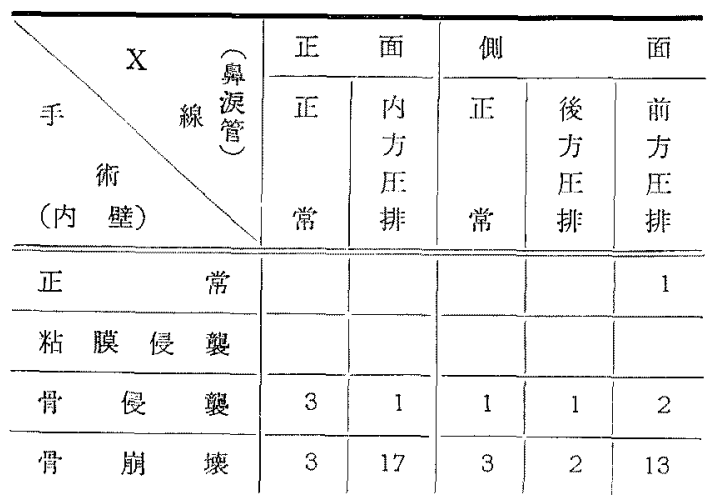

は閉塞を示す.一致率は21/30である。

側面撮影では正常例 9 例中 2 例と粘膜侵副例 7 例中 1 例がレ線上も正常である他㱠ど類似の結果を示し，一 致率子22/30 と殆ど同じである。

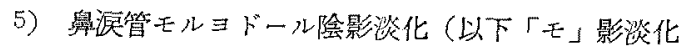
之略す）（表 37）

正面撮影では正常例 8 例全てが軽度淡化を，粘膜侵頨 例 7 例中 3 例 例は正常で，骨侵㽬例 3 例中 1 例が軽度淡化走示し， 2 例は正常で，骨崩壊例 6 例中 4 例が軽度，2 例は高度淡 化老示可

側面撮影でも殆ど類似の結果を示す

6)累添管走行異常と内壁との関係（表38）

走行異常の基準は本村に做い, 上部々下部の中点を結 ぶ直線が水平面となす角度が正面像では9 $93^{\circ}$ 土5

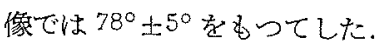

正面撮影では内壁の骨侵蟚例 4 例中 3 例が正常で，1
例は内方压排を示し，骨崩塄例 20 例中 17 例が内方压排 䓂示し，3例は正常である。

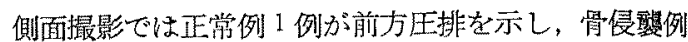
4 例中 1 例が正常で，他の1 例か後方圧排を，2例が前 方正排を示し，骨崩壞例 18 例中 3 例が正常で，2例が 後方理排，13 例加前力王排を示す

E）外项動脈造影撮影乞手術所見上の比校

1) 正 常 像 (表 10)

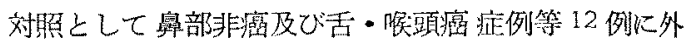
頸動脈造影撮影を行い, 顎動脈及びその分枝の正常像と して次の加き所見を得た。即ち，政動脈は外頸動脈より 分忮後，正面像では側上方へ凸面を向けた緩い弧を描き つつ内上方へ向い，側面像では直線的に前上万へ向う。

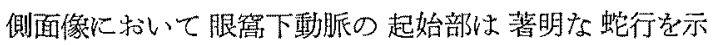
し，眼筒下壁に沿い上万に面を向けた緩い、弧を描きつ つ前方へ向い，その末梢の前上类槽動脈は煩骨马前縁に 沿つて下向し，䫑顿脈より分岐し，硬口洼に沿つて前方

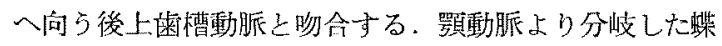

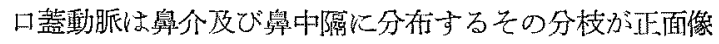
に执いかかり密で蛇行を示している。

2)上顎 癌 (表11)

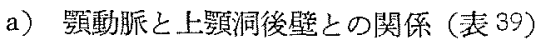

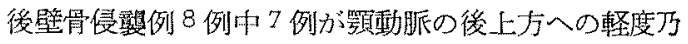
至中等度転位を，他の1例它高度転位を示し，骨欠損例 11 例中 10 例が軽度乃至中等度転位を示すが，1例は漴 位を示さない，一致奖は18/19の高率である。

b）顎動脈之上顎洞外壁之の関係（表 40)

外壁正常例 2 例中 1 例が顎動脈の側方への転位を示さ

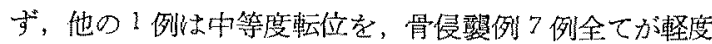

表 39 㖣動眽上後壁との関使

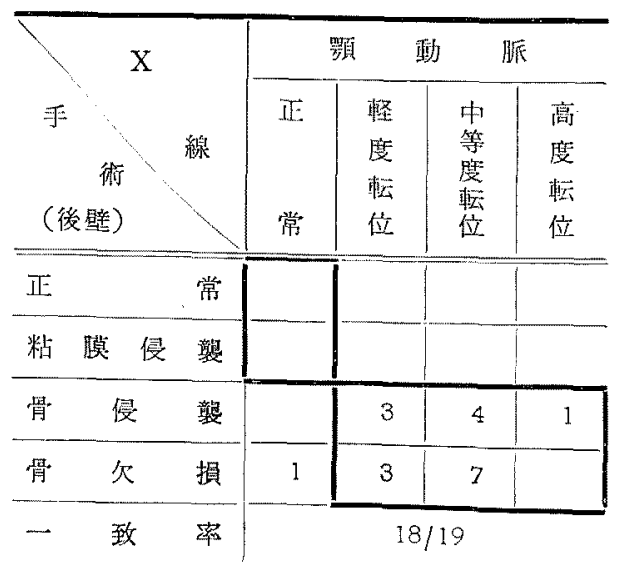




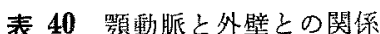

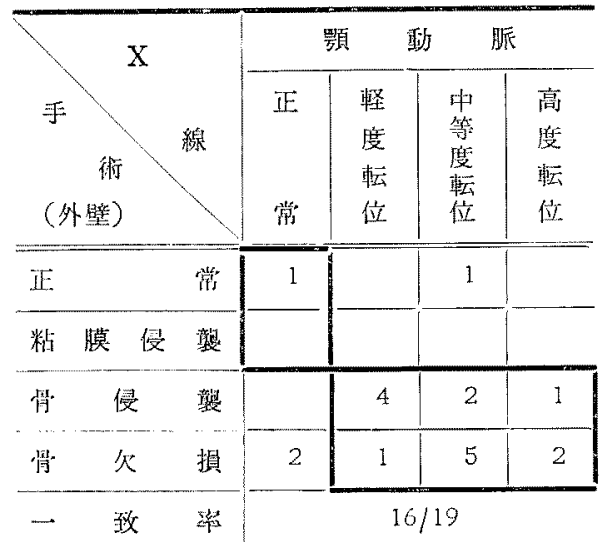

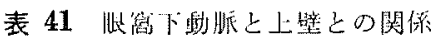

\begin{tabular}{|c|c|c|c|c|c|c|c|c|c|}
\hline \multirow{2}{*}{ 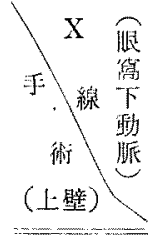 } & \multicolumn{4}{|c|}{ 起始部蜫行 } & \multicolumn{5}{|c|}{ 上阮乘 位 } \\
\hline & $\begin{array}{l}\text { 蛇 } \\
\text { 行 } \\
\text { 隔 } \\
\text { 度 }\end{array}$ & 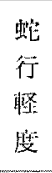 & $\begin{array}{l}\text { 蛇 } \\
\text { 行 } \\
\text { 消 } \\
\text { 失 }\end{array}$ & $\begin{array}{l}\text { 動 } \\
\text { 脈 } \\
\text { 消 } \\
\text { 失 }\end{array}$ & 㦂 & $\begin{array}{l}\text { 䠕 } \\
\text { 度: } \\
\text { 転 } \\
\text { 位 }\end{array}$ & $\begin{array}{l}\text { 中 } \\
\text { 等 } \\
\text { 度 } \\
\text { 梳 } \\
\text { 位 }\end{array}$ & $\begin{array}{l}\text { 嵩 } \\
\text { 度 } \\
\text { 転 } \\
\text { 位 }\end{array}$ & $\begin{array}{l}\text { 聥 } \\
\text { 脈 } \\
\text { 消 } \\
\text { 失 }\end{array}$ \\
\hline 裳 & & 1 & 1 & & & & 1 & 1 & \\
\hline \multicolumn{10}{|l|}{ 粘膜侵䧼 } \\
\hline 肖侵 繁 & & 1 & 2 & & & 2 & & 1 & \\
\hline 骨 久 椇 & 3 & 3 & 5 & 3 & & 5 & 4 & 2 & 3 \\
\hline 一致淘 & \multicolumn{4}{|c|}{$11 / 19$} & \multicolumn{5}{|c|}{$17 / 19$} \\
\hline
\end{tabular}

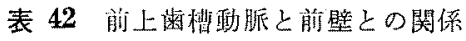

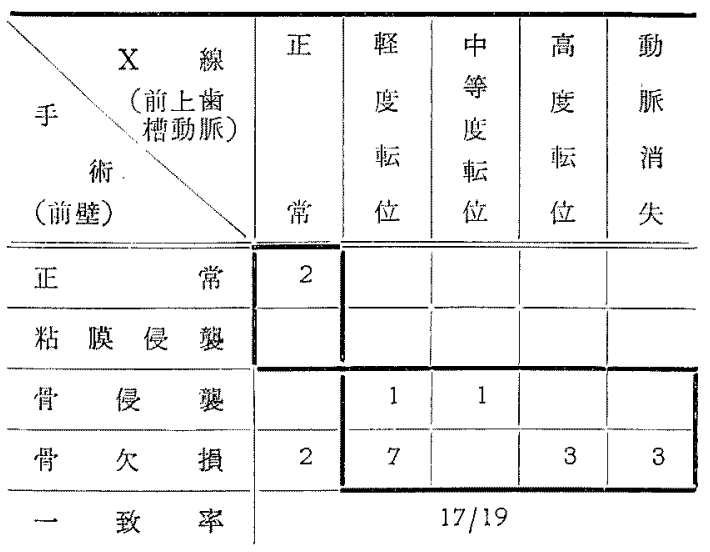

乃至高度転位示し，骨尔損例10 例中 2 例が転位を示

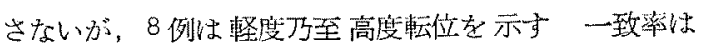
16/19である。

c）眼䆚下動脈と上顎洞上壁との関倸（表 41）

上壁正常例 2 例中1例が眼窝下動脈起始部の蛇个軽挺 で，他の1例出蛇行消失を，骨侵鸽例 3 例中 1 例が蛇行 軽度で，2 例は蛇行消失を示し，骨次損例 14 例中6例

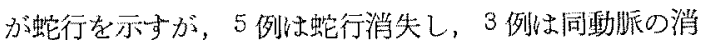
失を示している。一致率は11/19と余り良くない。

又，上壁上常例 2 例いずれも眼堂下動脈の上方への川

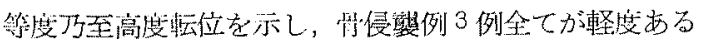
い虫高度檕位を示し，情次損例 14 例中11 例が軽度乃至

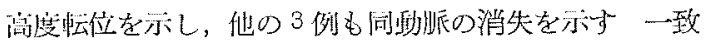
維は17/19である。

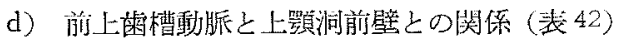

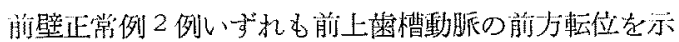
さず，骨侵警例 2 例いずれ子軽度乃至中等度牟位を示 L, 县欠損例 15 例中 2 例が転位走示さないが，10例は 軽度あるいは高度転位を正し，3例は同動脈の消失走示 す一致率は17/19である。

e) 後上歯槽動脈之上顎洞下壁との夙係（表 43）

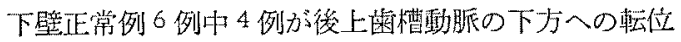
走示さないが，1例な軽度転位を，他の1例怯同動脈の

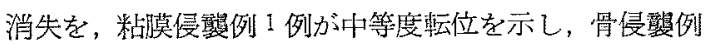
4 例中 1 例名転位を示さず，3例小軽度転位索示し，骨 欠損例 8 例中 3 例が軽度万垤高度轱位を示し，1 例舟動 脈消失を示す一致率は15/19である。

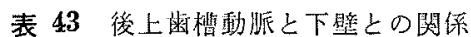

\begin{tabular}{|c|c|c|c|c|c|}
\hline 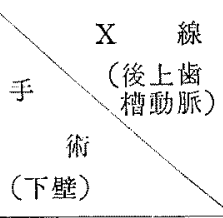 & 正 & 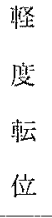 & $\begin{array}{l}\text { 中 } \\
\text { 等 } \\
\text { 度 } \\
\text { 讙 } \\
\text { 位 }\end{array}$ & 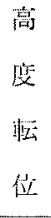 & $\begin{array}{l}\text { 彭 } \\
\text { 脈 } \\
\text { 消 } \\
\text { 失 }\end{array}$ \\
\hline 常 & 4 & 1 & & & 1 \\
\hline 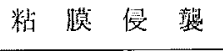 & & & 1 & & \\
\hline 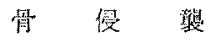 & 1 & 3 & & & \\
\hline 骨 久 摜 & & 1 & 5 & 1 & 1 \\
\hline 一 致 棌 & & & $15 / 19$ & & \\
\hline
\end{tabular}




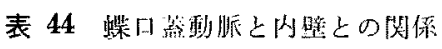

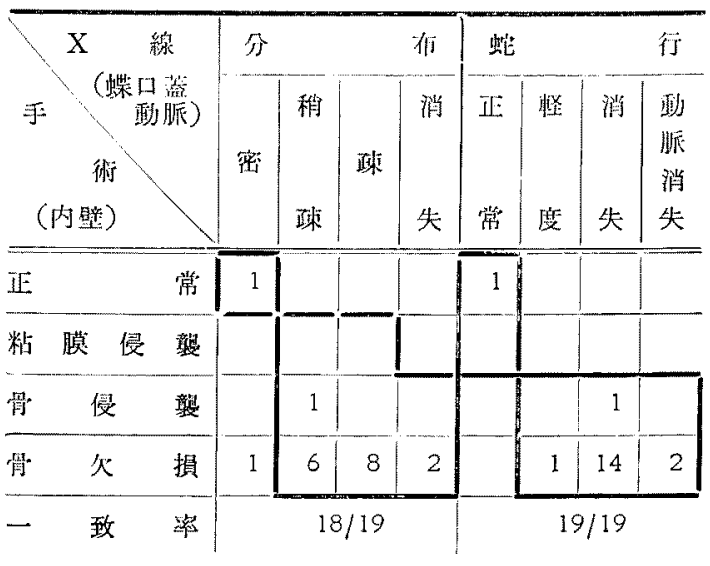

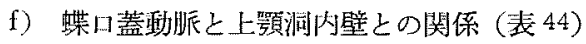

内壁正常例 1 例が喋口蓋動脈の分布が密で，骨侵塑例 1 例はやや眯を示し，骨尔損例 17 例中 I 例が分布密で， 14 例はやや柾か蹯を，他の 2 例も同動脈の消失を示す 一致率は $18 / 19$ の高率である。

又, 内壁正常例 1 例が堞口蓋動脈の蛇行著明で，骨侵 洷例 1 例が蛇行の消失を示し，骨欠損例 17 例中 15 例が 蛇行軽度乃至消失を，他の 2 例も同動脈の消失を示主 一致率は19/19 と100\%である。

\section{V. 総括並び考按}

\section{A）上顠洞陰影}

上影窞の X 線所見として先づ考えねばならない、事は 想側上頡洞の陰影增強である. Pfahler・Dodd 等は上顎 癌の X 線所見として三項目を挙げ, その一っとして上 颚洞の陰影增強を記載している。艺の原因として Gordon は腫嫣による軟部組織の增加と脂肪組織の腫瘍一 の置換を挙げている，Gilmore はその濃度はポリーブ によるガラス様の陰影より濃く，肥厚した粘膜や分泌物 による各種の陰影濃度が混在しておかり，墨性腫攅による

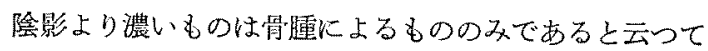
いる. Pfahler む Gilmore と同様に上颚洞陰影は偏在 性の不規則な陰影欠損の存在を示寸持を指搁している。

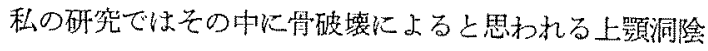
影の異常な透明化が各種単純・断層撮影で認められた。 その結果，上䫈洞㓌影山各症例で增強之透明化の濃淡の 入り交つた様相を示して扣り，私はこれを不規則性々呼 んだが，この不規則性は後頭前頭撮影で後頭頃撮影上り 落明で，各断層掓影では極めて著明である。それは後頭 賢撮影でけX楾が间・後壁に刘し斜めに投的されるため
に，上顎润陰影が管壁陰影と重り易くなる叔に起因し， 断曆撮影では四断㬝面での院影が夫へ描出されるだめに 詳䋖な読影が可能である事に由来寸ると考えられる。

上顎癌に際しての上顎洞陰影に就いて吉川は腫瘍によ

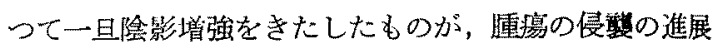
によつて骨融解をきたすと明澄化を見るようになると し，山本は患側上顎洞の陰影が透明な場合は顔面壁に骨 融解の認められる場合が多いが，骨融解任煩部腫脹が加 わると反つて㓌影は增強すると述べ，高須賀も上顎洞陰 影が濃く現れたり透明像として現れたりするが，後者で は周囲の骨吸収が著明であるのみでなく，霾堭組織の融 解の起つている例であると語つている。私の症例でむ上 顎洞陰影の透明化の見られる例が半数を占め，このよう な例では前壁の骨崩壤著しく，骨崩壊が著明でも煩部隀 脹の著しい例及び骨崩爙部の小さい例では透明化を示し ていず，上述の諸家の報告を裏付けている。

B）上顎洞骨壁

更に重要な所見は上顎洞骨壁の状態である.太田は副

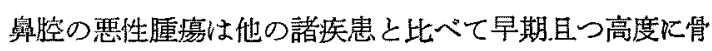

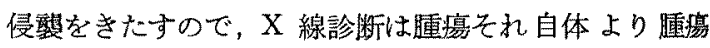
による骨崩壊の観察に主眼が置がると述べ，Dodd は

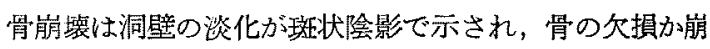
罗は腫場の確実な診断となるとしている，更に，彼及び Pfahler は前述の上顎癌の X 線所見の三つの特改の一 つとして骨影增強・骨久損等の骨陰影の变化を举げてい る. Gordon は上顎洞の骨欠損に性腫境の摭大による变

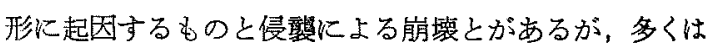
後者に基くものであるとし，Pfahler は腫瘍による骨

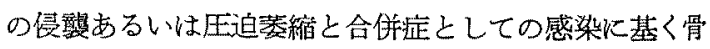
䯣炎による破壞が見られるのであると述べている，又， 皆崩塄の前段階と考克られる骨陰影の增強は Dodd 以

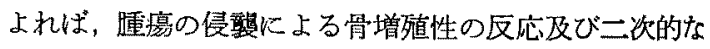
慢性炎症性の反応基くものであると云う、私の研究で も全例でいずれかの骨壁に欠損が見られ，X線写真で もこれに一致して洞輸廊の断絶・消失を示す例が多い

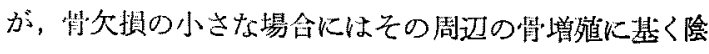
影で打消されて，X 線上洞輸郝の厚化像として示され る㳟住があり，この現象は当然算純撮影に打いて著し

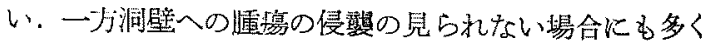
は $\mathrm{X}$ 線上洞輪劰の厚化が現れるが，これは二次的な炎 症性紧化が洞壁に及んだためでなく先行していた炎症に

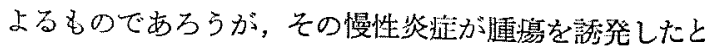
云う証䢞はない 
吉川は上顎洞壁は X 線により切線的に投影された場 合に最も適確に判諘され，上壁の観察には鼻位法（原文 のまま，以下同様）が適しているとし，Pfahler に上れ ば上壁は各種の矢状位及び斜位撮影火よって良く描出さ れると云う、私は後頭前頭・後頭傾・Rhese 氏法撮影 及び前頭・矢状断層撮影で上壁の観察をしたが，後頭前 頭撮影で手術所見との一致率が最低を示した，これは同 撮影では上壁に側頭骨錐体部除影が重眰するために，䛃 影が難しい事によるものと考えられ，当然断賣撮影特に 矢状断增撮影で著しく良い一致率を示している。

下壁は Pfahler に上れば彼の斜位法が最も良く描出 すると云う、私は上壁と同じ撮影を行い，単純撮影では 後頭虍提影で他の撮影々比べ一致率が良からたが，とれ は同撮影では荬牙残存の認められる例で下壁の読影が不 能なために除いてあるが故であろうか，単純・断層撮影 間には著しい差は認められない

内壁の観察には吉川によれば前頙位・鼻位法が適して いると云う．私は後頭前頭・後頭願撮影及び前頭・水平 断層撮影を行つた．後頭賾は後頭前頭撮影より，水平断 層は前頭断層撮影より一致率が良からたが，それは後頭 前頭撮影で内壁に重畳する椎骨陰影が後頭覧撮影では除 かれるためと，水平断層撮影では前頭盺層撮影より紐か く内壁を切断したためであると考えられる，単純撮影に 比べ断層撮影で一致率が良いのは当然である。

外壁の描出には前頭位・鼻位法が適していると吉川が 述べている.私は内壁と同じ撮影を行い，単純撮影問で は一致率に差はなく，断層撮影では水平断層撮影で一致 率がやや良いが，こ机は内壁の場合と同じ理由による う。ここでも断圈撮影が単純撮影より一致率が良い。

前壁は Pfahler の斜位法が良く描出すると Pfahler は云っている. 私は矢状・水平断層撮影で観察した，両 者共一致率は極めて良い。

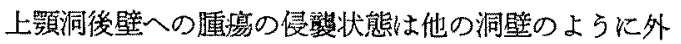
来診察では知り難く，しかも一般に行わ机ている矢状位 撮影・前頭断層撮影でも描出不能であり，古来多くの研 究者の探求に拘らず，未だ満足すべき状態ではない，恶 性腫晹での側後壁の診断的意義を初めて提唱したのは本 城であり，彼は後頭前頭撮影で側後壁を TM 線として 投影しており，山本も TM 線の消失は側後壁の骨融解 と密接な関係があるとしている。しかし，この線は必ず 描出されるとは限らず，吉川は Rhese 氏法では側後壁 が X 線で切線的に投射されるので，その観祭に適して いると述へ，一方 Pfeiffer は軸位法に拁いて上䫇洞の前
後片问の観察が可能であると語つている、メ，最近の断

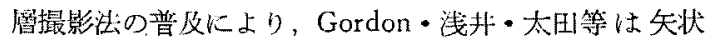
断層撮影が上颚洞の前後方向の钼祭に適しているとし，

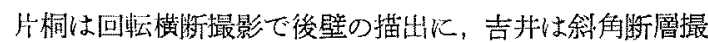
影で側後壁の描出に成功している，私は軸位，Rhese 氏法，矢状・水平䉼層撮影を行つた，一致率は軸位撮影 に比べ Rhese 氏法で著明に良いが，これは後者では側 後壁の上下軸が長い陰影として描出されるのに対し，前 者では壁が幅の狭い除影として描出される柬の差化上る と考えられ，断層特に水平断䱜撮影では単純撮影より一 致率が良い

眼简下孔の観察は後頭碩撮影で叮能であり，上壁と䎹 接な関係を持占，X 線上眼简下孔に異常所見の見られ る時は上壁への腫湯の侵酸が考光られる。

C) その他の副舆洞

節骨蜂筧の観察には古くは側位撮影が用いられていた が，この方法では左右陰影の重嘼をきたすために診断的 価值は譛められず，徭頭前頭撮影・Rhese 氏法の考案 により診断的応用が可能となつたが，断層撮影法の歨用 化により更に䛦断的確度が高まつた，即ち，高須賀は節

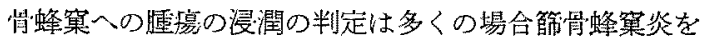
合併しているので単純写真で林困難であるが，断疽写真 では䗋窠壁及びその隔壁の破填像の確認に上り鑑別がで

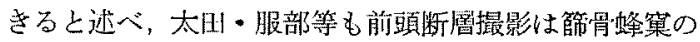
钼察に適しているとしている，又，Gordon・浅井・太

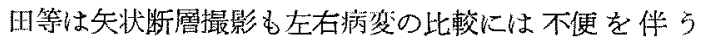
が，同部の描出に適しているとし，片桐は回転横粍撮影 で同部の描出代成功している。私は後頭前頭・前頭断船 撮影で節骨蜂策を，又この二法之後頭願撮影で䋊状板の 観察を行つた，即ち，X 線上紙状板に厚化・断絶・消

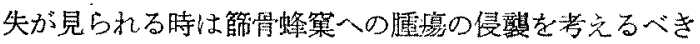

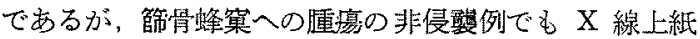
状板の厚化を認める場命が多く，それは高須賀の述べて

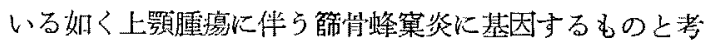

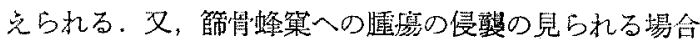
は例外なしに X 線上蜂策隔壁の䉼絶・消失が現れると 云ってよい。

蝶形洞の観察は初めは側位撮影で行われていたが，篩

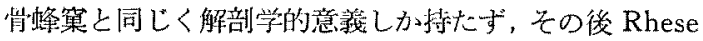
が惵形洞観察の目的で始めた斜位法と, Spiess・Pfeiffer 等の考案になる軸位撮影が尃らとの彰断に用いられ， Pfeiffer・橋本・服部等が泛の洒值を認めている。文， Pfahler は彼の考案になる斜位法で蝶形洞の描出が可能 
であると述べている。しかし，近年浅并・太四・服部等

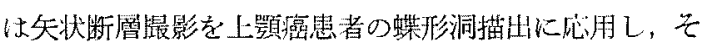
の観祭に適しているとし，Epstein もこれ迄の䁋形闹撮 影法では附近骨組䅧陰影の影響で判然としなからた前・ 下壁と蝶形骨备翼林このう法では判然と描出されると强

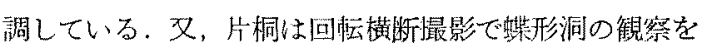

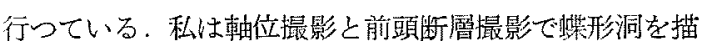
出し，特に前頭断層撮影ではかなり焦明な洞壁陰影を

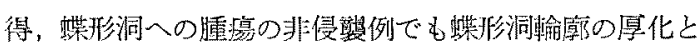

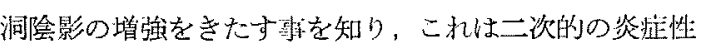
変化であると考えた，視神経孔の钼祭を Rhese 氏法で 行い，孔翰廓之除影の X 線所見と上壁の手術所見とが

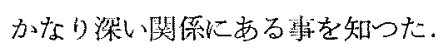

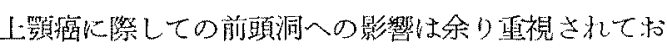
らず，その報告も少いが，Pfeiffer は後頭前頭撮影で存 在しない邚く見える小さな前頭洞も軸位撮影では観祭で きるとし，Ackerman は上碚癌の際に前䫒洞に二次的 炎怔による院影增強が見られると述へ，Haas が、他の副

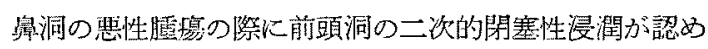

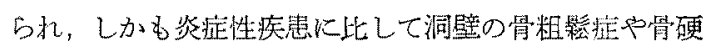
化定が多く見られると云つているのに対して，Gordon は28\%にそれが琹められたと報告している。私は後頭

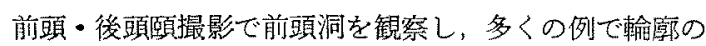
軽度厚化と陰影の中等度增強を認め，前述の諸報告との 一致を見た。

D) 鼻腔内各部

梨状孔緣の観察は Rhese 氏法で可能であつた．X 線 所見と手術所見とは症く一致し，梨状孔縁の状態は Rhese 氏法が忠实に描出する事を知つた。

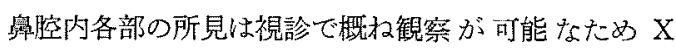
線所見は余り重視されていないが，Pfahlerは上㧵癌

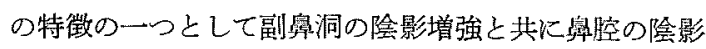

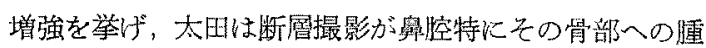
瘁の侵㢣を知る上で極めて有意義であるとしている、私

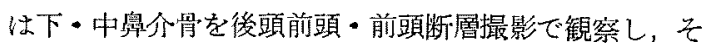

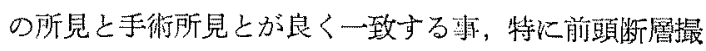

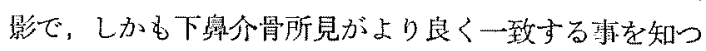

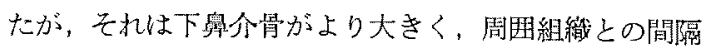
が保たれているためと考える。

奥底骨の観察も上記一撮影で行い，後頭前頭撮影でX 線所見と手術所見とが一致しない例がかなりあつたが，

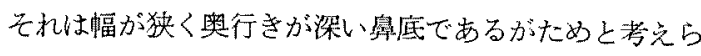
れそれも断層撮影ではかなりの改眉が認められた。
鼾中滆も同じ二撮影で観察し，率中區の対側への著明

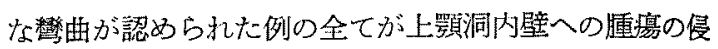

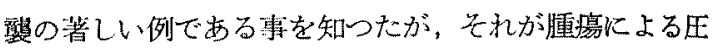

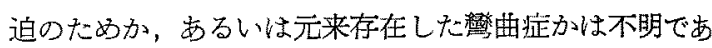
万.

涙道の観祭に就いては本村が 40\%モルヨドールを用

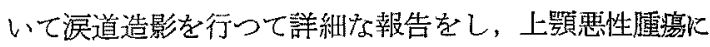

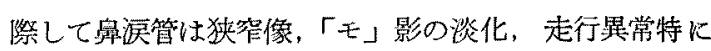

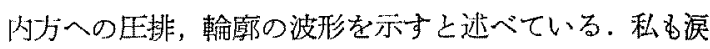
道の造影撮影を行い，正面・側面撮影を行つた。添碳で

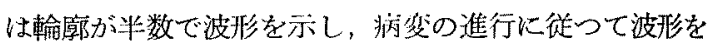

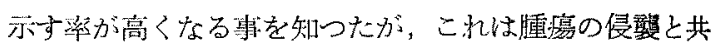

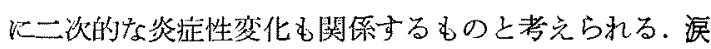

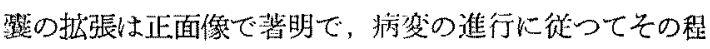
度が高度となる傾间定している。

鼠涋管では翰廓が大多数で汥形を示しているが，これ

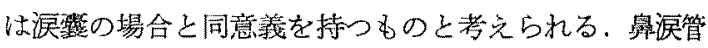
の狭窄は畵湯の侵㢣例では側面像で 1 例に認められなか つた他は全てに認められ，しか子病变の進行に従つて狭 窑の程度も高度となつているが，正常例で电狭窄を示す 例が多く，これは二次的な炎症性変化が管粘膜に及儿で いる静を示すbのであるら「モ」影の淡化も多くの侵 弉例で見られるが，正常例でも大多数で諗められ，これ も前述の理由に基くものと考えられる．次で舁沃管の走 行異常と内壁との関係を探索した所，多くの例で正面像 では内方圧排を，側面像では前方理排を示し，元の関係 の深さを知つた。

E) 翼状突起亡煩筒

上顎洞後方即ら翼口蓋㗐及び翼状突起等はそこへの腫 瘍の侵融が視診では知り難く，しか子腫瘍の進展し易い 部位であるがために重要な部位であり，従つて X 線的 検索が重要視され，古来多くの報告がなされている，高 須賀・太田・估藤等は前䫄断層撮影で，浅井・太団等は 天状断屡撮影で，佐滕は水平断層撮影で翼状突起陰影の 観察を行い, 㟝断の一助としている。私は軸位, 前頭・

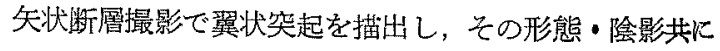
両率尿撮影が軸位撮影に比べて良くその状態を示してい る事を知つた。 又, 翼状突起㓌影々上顎洞後壁との関係 を調べたが，いずれの撮影でも後壁病答の進行程度と翼 状㔖起陸影の程度とがかなり度く一致する事から雨者の 関係の深い、垔が判つた。

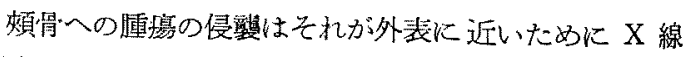
写真への依存卙は低く，殆よ゙報告も見られない，私は軸 
位，前頭・水平断層撮影を行い，煩骨陰影を観察し，前 頭断圏撮影で最高の一致率を示す事を知つた。

F) 外頸動脈之上顎洞各壁の関係

外頸動脈撮影儿関する埌告は内頸動脈のそれに比べれ ば䝉めて稀である。それは診断的価值の軽重と手挍の難 易によるるのであろう.上顎洞附近の悪性腫湢への応用 は Schrudde が数例の患者に行つているのみであり， 彼は同部の悪性腄瘍の存在は血管の走行異常から知り得 ると云つている。私は19 例の上顎澏患者に本法を行い， 䫇動眽及びその分枝と上顠洞各壁との関係を追求した。 即占,

1）後壁に瘟腫の侵㢣のある时には，顎動脈が後上方 に転位する。

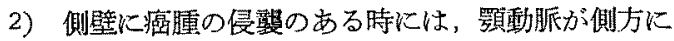
枟位与る。

3）前壁に癌尰の侵裂のある時には，前上雬槽動脈が 前方に転位する。

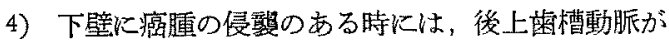
下方机転位する。

5）上壁に癌腫の侵警のある時には，眼简下動脈が上 片轱位すると共に，同動脈起始部の蛇行が見られなく なる。

6) 内壁に癌腫の侵被のある時には，蝶口蓋動脈の分 布が蹯となると共に，同動脈の蛇行が見られなくなる。

以上の中，各動脈の転位は腫撽による王排に起因し， 蛇行の減少・消失も腫疬の圧迫によるものであり，分布 が眯となる事は鷹瘍による血管の蚕蝕に基くもので，こ の他数例に扣いては眼筒下，前・後上菤槽，蝶口蓋動脈 の消失が見られたが，それも腫瘍による血管の叠蝕に原 因を求めてよいるのと考觉る。

\section{VI. 結語}

30 例の上顎癌患者に前記の諸種X線撮影法を行い， 手術・摘出標本・大切片標本所見上比較検討し，次の結 論学得た。

1) 単种・断圓の各撮影においては上顎癌特有の”所見 として，上哭頁洞㓌影の增強，洞骨壁の厚化，それの進ん だ断絶・消失が見られ，それに伴つて增強した洞㓌影の 中に明澄部が現れる。

2)篩骨蜂檾であ同様な所見が見られる。

3）蝶形洞の所見は軸位撮影・前頭断風撮影で良く観 察できる。

4) 前頭洞では炎症性変化としての洞㓌影の增強と洞 骨壁の厚化が見られる。
5) 上顎洞後壁及び 翼状突起の所見は軸位摄影, Rhese 氏法，矢状・水平断層撮影であ良く観察でさる。

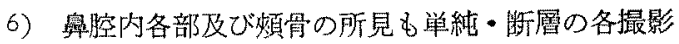
所見と良く一致する。

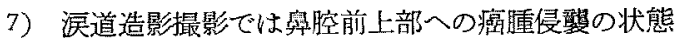
が観察できる。

8) 外頸蜆脈造影撮影では顎動脈及びその各分枝の䛃

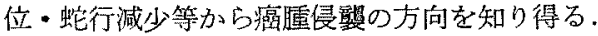

\section{主要倠考文献}

1) Ackerman, R.V.: Carcinoma of the maxillary sinus, Cancer, 241, 1962. 2) Albrecht, W.: Die Bedeutung der Roentgenographie für die Diagnose der Nebenhoehlen Erkrankungen, Arch. f. Laryngol., 20；175, 1908. 3) 絧野三郎他：上顎癌手術前放

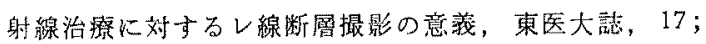
521, 1959. 4) Andrews, J.R.: Planigraphy, Am. J. of Roentgenol. and Rad. Therapy, 48; 625, 1942. 5) Arslan, M.: Collagen diseases of the upper respiratory tract, Ann. of Oto-Rhino-Laryngol., 67; 279，1959.6）浅井良三他：上颚腫舅の断層层影に ついて，耳隐，51；692，1958. 7) 浅井良三：上買

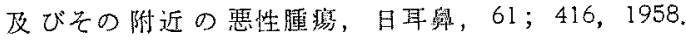

8) Boczon, S.: Moeglichkeiten der Tomographie in der Otolaryngologie, Zent-blatt f. H-N-O., 48; 143, 1953. 9) Bouchet, $M$. etc.: Zur systematischen Tomographie bei der Roentgen untersuchung der Sinus des Gesichtsschaedels, Zent-blatt f. HN-O., 52; 163, 1955. 10) Caldwell, E.W.: Roentgenographie der Nebenhoehlen der Nase, Ref. Fortschr. a.d. Geb. d. Roentgenstr., $11 ; 299,1907$. 11) Coakley, C.G.: Skiagraphie als ein Heilmittel bei Diagnose und Behandlung von Erkrankungen der Nebenhoehlen der Nase, Zent-blatt f. Laryngol., 1906. 12) Cone, A.J.etc.: Relationship of paranasal sinus disease to ocular disorders, Laryngoscope, 49; 374, 1939. 13) Denker, A. etc.: Roentgenuntersuchung der Nase und der Nasen Nebenhoehlen, Handbuch d. Hals-Nasen-Ohren-Heilkunde, I; 953, 1925. 14) Dodd, G.D etc.: The systematic use of tomography in the diagnosis of carcinoma of the paranasal sinuses, Radiology, 72 ; 379, 1959.

15) Eckstroem, G. etc.: Gehirnschaedigungen nach cerebraler Arteriographie mit Thorotrast, Zent 
-blatt Neurochir., 3;227, 1938. 16) Epstein, B.S.: Skull laminagraphy, Radiology, 38; 22, 1942.

Epstein, B.S.: Laminagraphy of the sphenoidbone, Am. J. of Roentgenol. and Rad. Therapy, 48; 625, 1942. 18) Fraser, R.H.: Iodized oil in otolaryngologic diagnosis, J. Michigan M.Soc., 25; 270, 1926. 19) Gilmore, J.H.: Malignancies of the nose and nasal accessory sinuses, A.M.A.Arch. Oto-Rhino-Laryngol., 66; 595, 1956 . 20) Goldmann, E. etc.: Über die Verwendung der X-Strahlen für die Bestimmung der nasalen Nebenhoelen und ihrer Erkrankungen, Beitr. Z. Klin. Chirurgie, 54; 1,1907

21) Gordon, I.R.S.: The radiology of malignant tumors of the nose, J. Laryngol, and Otol., 69; 786, 1955. 22) Haas, L.L.: Secondary alterations of the frontal sinss in cancer of the paranasal sinus, Am. J. of Roentgenol. and Rad. Therapy, 62; 797, 1942. 23) Haike, H.: Die Roentgenuntersuchung der Nasennebenhoelen der Kinder, Arch. f. Laryngol., 23; 206, 1911. 24) 浜崎端：舆腔 - 副奥腔悪

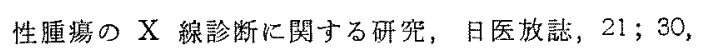
1961. 25) Haemmerli, $F$, etc.: Über die Arteriographie der Extremitaeten und Hirngefaesse mit Athyltrijodatearat, Zent-blatt: 66, 45, 2433, 1939.

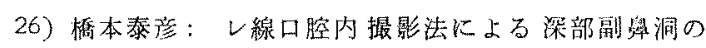
観察並に立体撮影法の一考案, 耳鸣，15；325，1942.

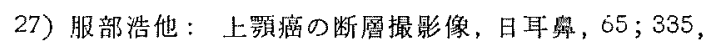

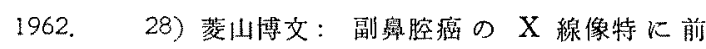
頭洞の形態との関係，日耳鼻，62；602, 1959. 29) Holvey, E.H. etc: Tomography in the region of the maxillary sinuses, Radiology, 42; 458, 1944. 30) Holvey, E.H. etc.: Tomography of the skull, Radiology，44；425，1945.31) 本庶正一：上買癌 の早期䛦断，医学，9；120，1950.32）本城明朗他： 上颚洞悪性瘇瘍のレ線的観察，耳臨， $35 ; 189,1940$.

33) Houser, K.M.: Diagnosis and treatment of primary malignant neoplasms of the maxillary sinus, Arch. Otolaryngol., 18; 643, 1933. 34) 飯森

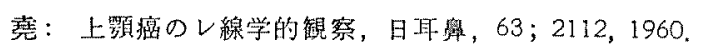

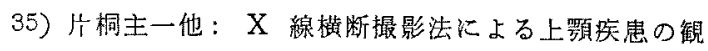
察，日耳與，57；255，1954.36）小山三郎他：上顎

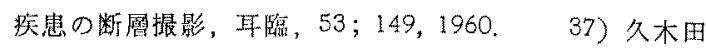

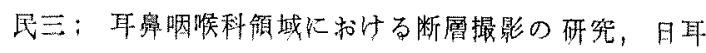

粤, 62; 1901, 1959.

38) Kuttner, A.: Die entzundlichen Nebenhoehlen Erkrankungen der Nase im Roentgenbild, Atlas u. 20 Photogr. Tafeln, 1908. 39) Law, F.M: Nasal accessory sinuses, Ann. of Roentgenol., 15; 32, 1933. 40) Loehr, W. etc.: Die kombinierte Encephalo-arteriographie, Arch. klin. Chir., 173；1932. 41) 松田家一他：上頻癌に 対寸る断層レ線像の洒值，耳臨，47；89, 1954。42) Moniz, E.: A prova da encefalografia arterial, Lisboa Med., 4; 1927. 43) More, S.etc.: Body section roentgenography with the laminagraphy, Am. J. Roentgenol. and Rad. Therapy, 30; 514, 1938. 44)本村宏：淚道のレ線学的研究知見補遙，千葉医誌， $33 ； 995,1958.45)$ 二之湯夈：上顎癌に際する断層 撮影，名市大医壴，4；216，1953.46）野中貞二郎： 䫝面の断層写真，日耳鬼，56；284，1953。47) 太田

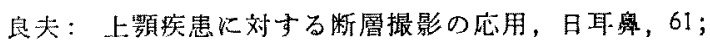
1382，1958.48）太田良夫：上顎疾患に対する断㜿

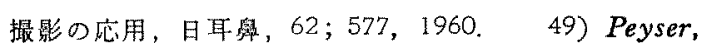
A.: Die Roentgenuntersuchung der Nasenneben. hoelen, Arch. f. Laryngol., 21 ; 126, 1909. 50) Pfahler, G.E.: The roentgenographic study of the accessory sinuses with special reference to the new technic for the examination of the sphenoid sinu. ses, Ann. of Oto-Rhino-Laryngol., 30; 379, 1921. 51) Pfahler, G.E. etc.; Roentgendiagnosis of cancer of the accessory sinuses, Arch. of Otolaryngol., 31; 561, 1940. 52) Pfeiffer, W.: Beitag zum Wert des axialen Schaedelskiagramms, Arch. f. Laryngol., 30; 1,1916 53) Pfeiffer, W.: Eine neue roentgenographische Darstellungs methode der Keilbeinhoehlen, Arch. f. Laryngol., 23; 420, 1911. 54) Rhese: Die chronischen Entzündungen der Siebbeinzellen und der Keilbeinhoehle, Arch. f. Laryngol., 24; 383, 1911. 55) Riechert, T.: Die Arteriographie der Hirngefaesse, 1949 . 56) 酒井俊一

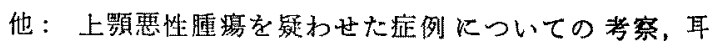

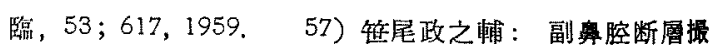
影の経験，日耳厸，57；1028，1954。58) 佐藤铨焳： 副奥腔断橎撮影について，日耳奥，63；884,1960. 59) Scheier, M.: Zur Anwendung des Roentgenverfahrens bei Schussverletzungen des Kopfes, Dtsch. Med. Wochenschr., 40; 648, 1896 60) Scheier, 


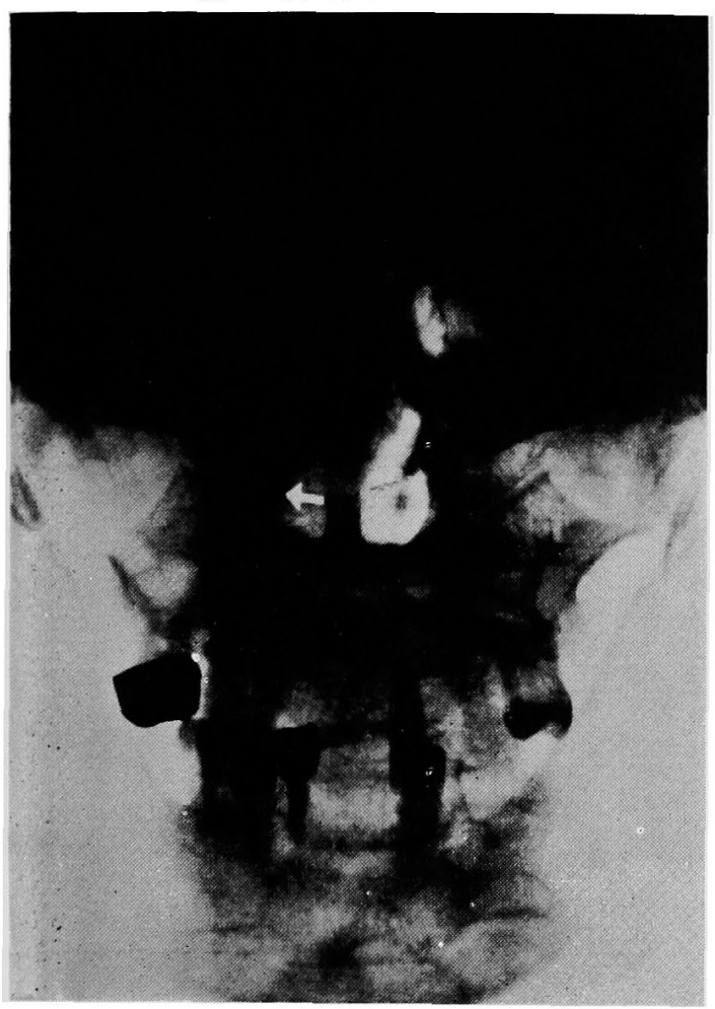

症例 27. K.S., 万 57 才, 右上䫇癌 上嶺洞側壁の崩壊 (大矢印) 同内壁の厚化 (小矢印)

図 3 軸位撮影
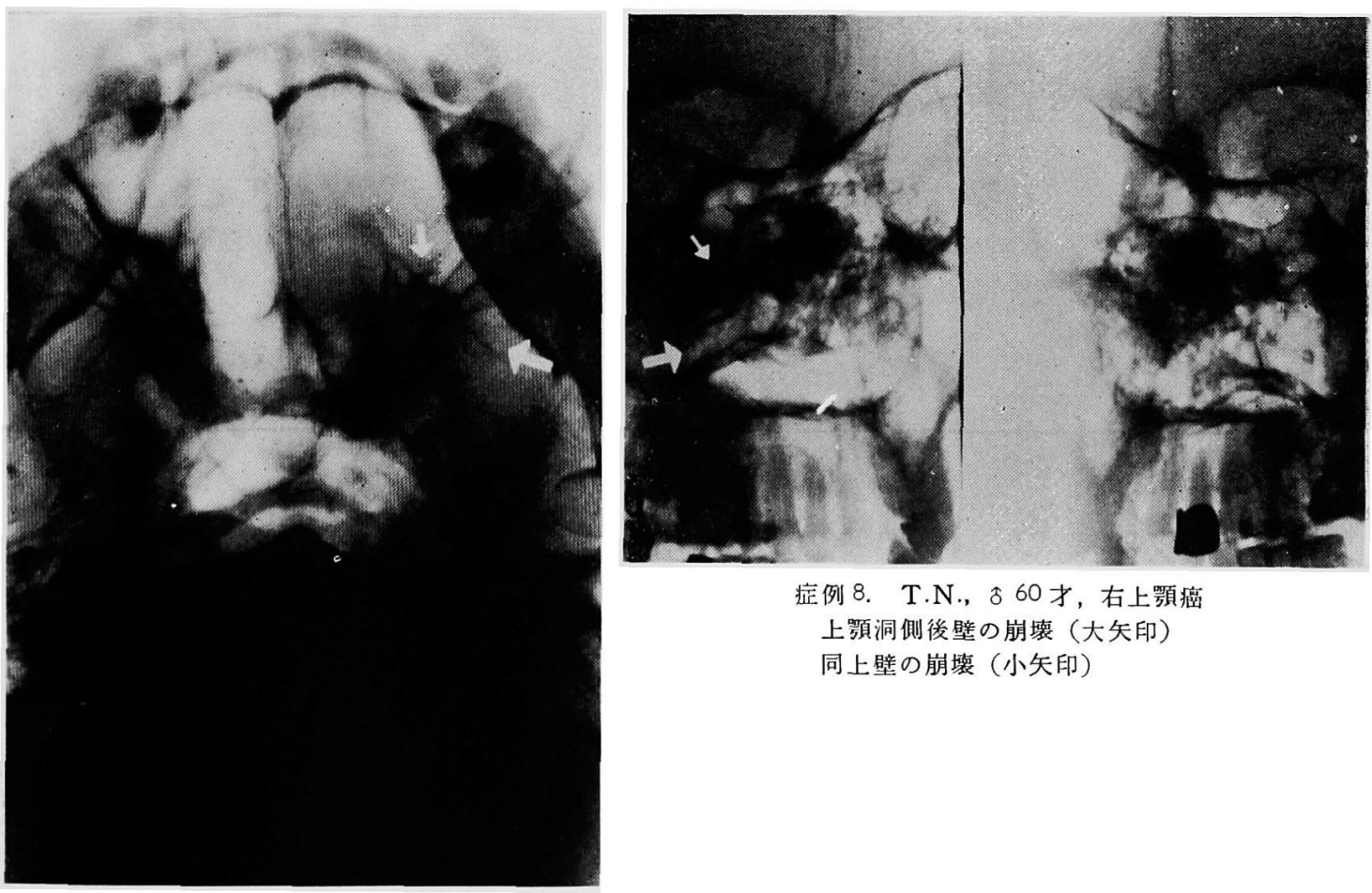

症例 8. T.N., 860才, 右上顎癌 上顎洞侧後壁の崩壊 (大矢印) 同上壁の崩壤 (小矢印) 


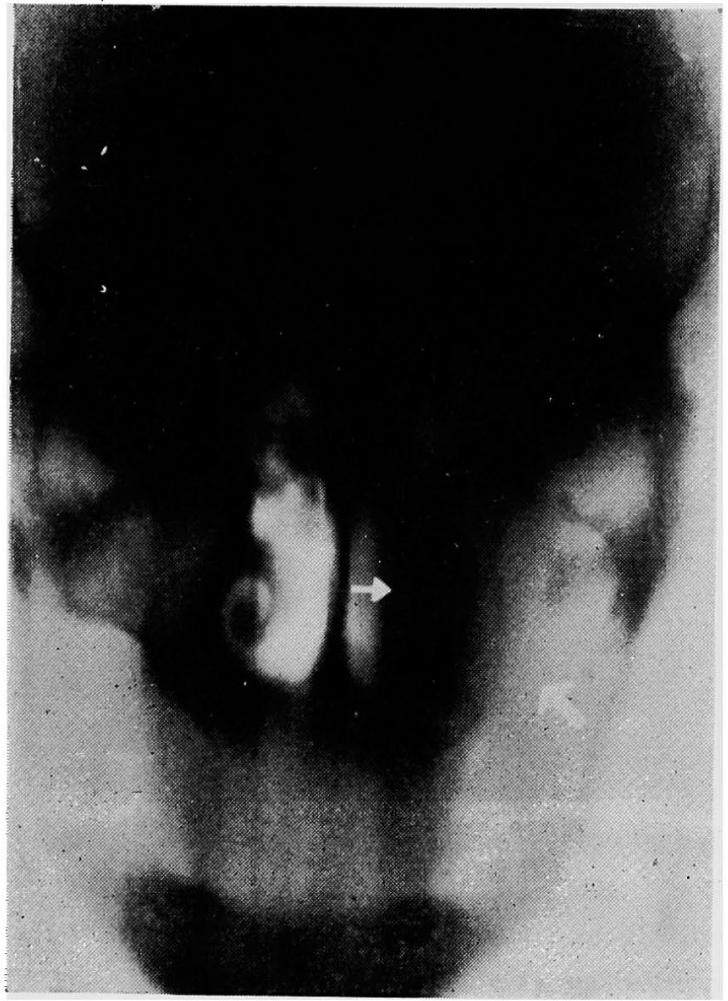

症例 18. S.O., 早 63 才, 左上顎癌 上顎洞側壁の崩壁 (大矢印) 同内壁の厚化 (小矢印)

図 7 矢状断層撮影（第 2 面）

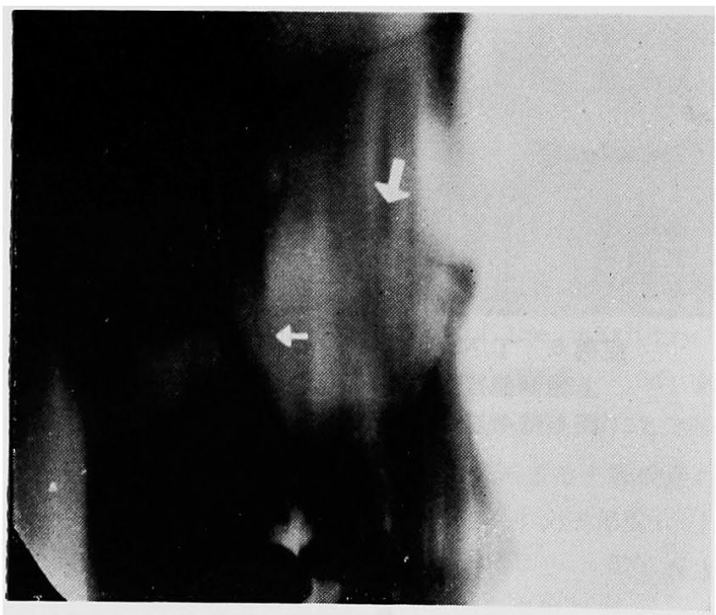

症例 8. T.N., 8 60 才右上顎癌 上顎洞上壁の崩壊（大矢印） 同後壁の崩壞 (小矢印)

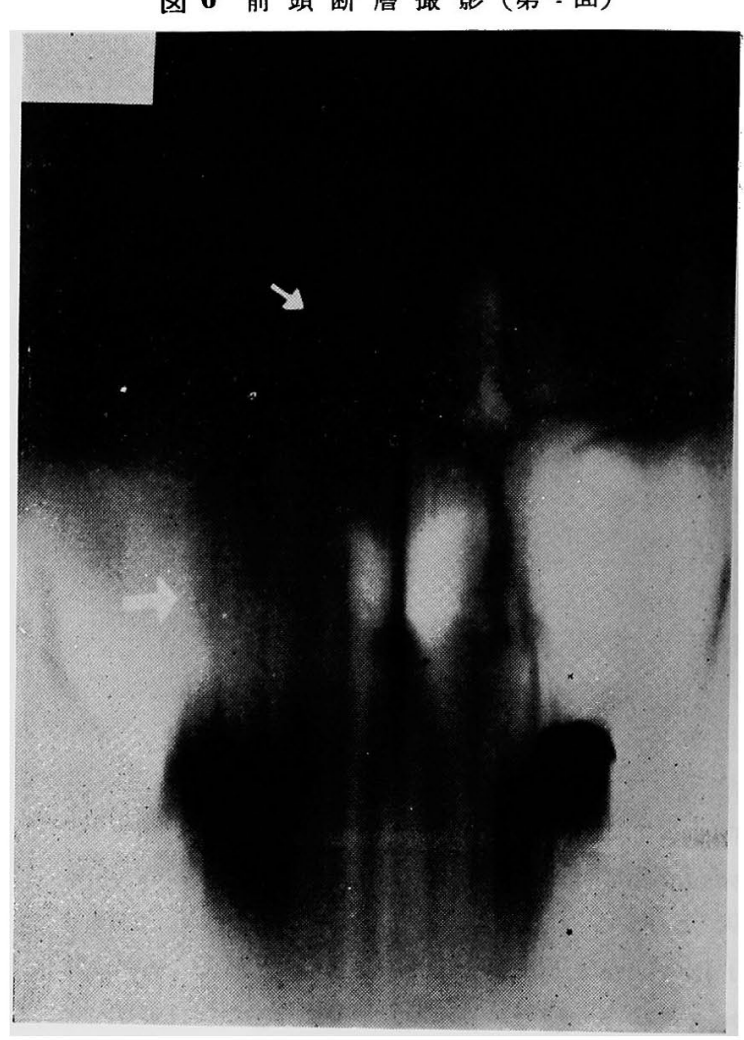

症例 15. M. I., 우 46 才, 右上顎癌 翼状突起の崩壊（大矢印） 蝶形洞への腫瘍の侵襲 (小矢印)

図 8 矢状断㬝撮影（第 4 面）

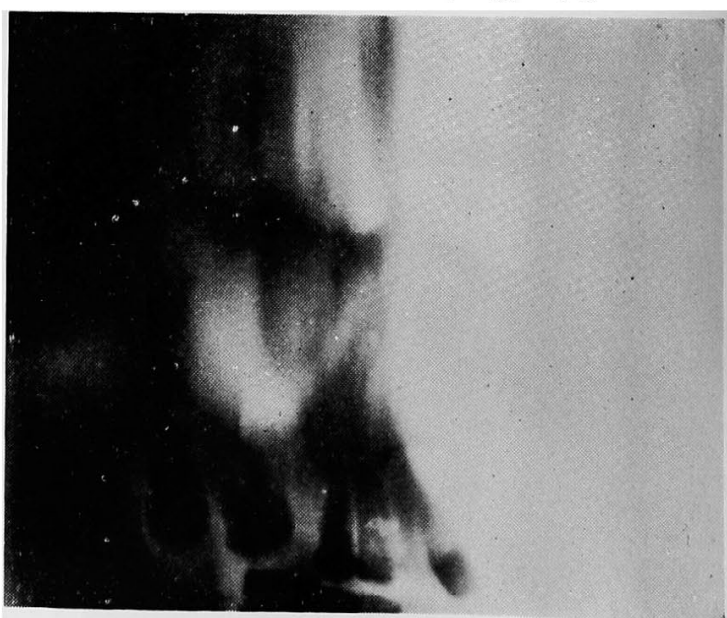

症例図7と同じ

健側上罘洞とその周辺部 


\section{相 原 論 文 付図（III)}

図 9 矢状断層撮影（第 2 面）

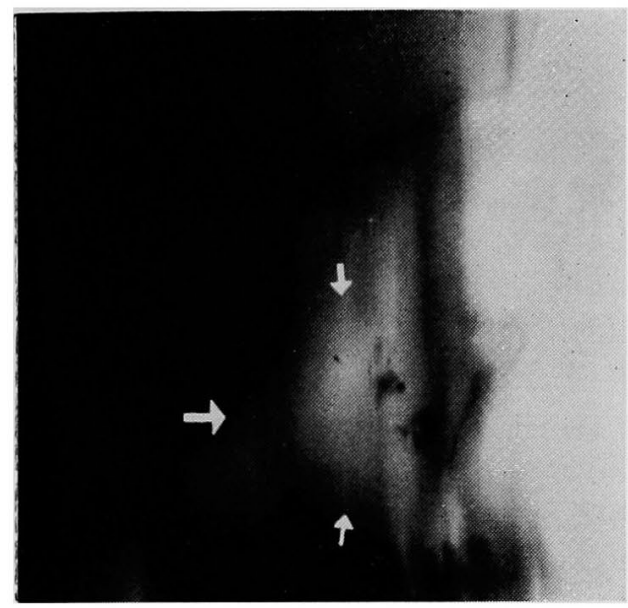

症例 15. M. I., 4才. 右上顎癌 上顎洞上・下壁の崩壊 (小矢印) 翼状突起の崩壊 (大矢印)
図 10 水平断㬝撮影 (第 2 面)

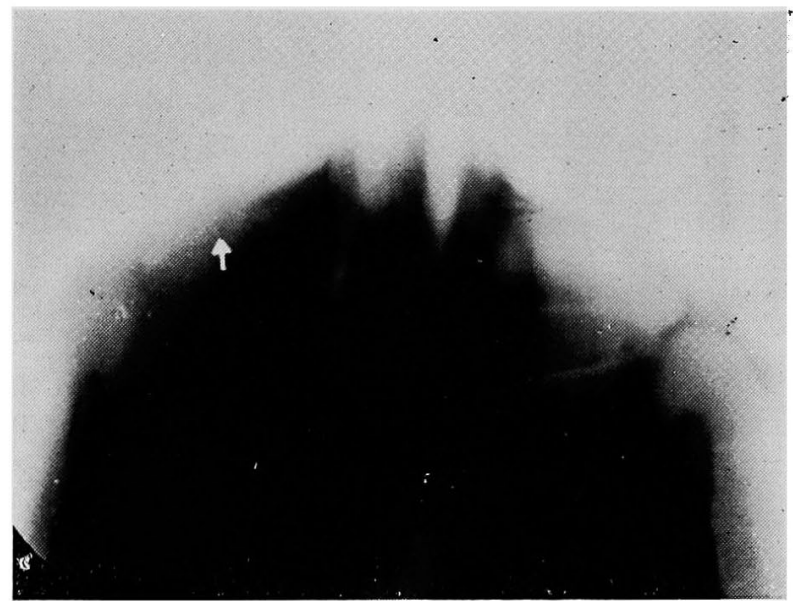

症例 9. T. I., 70 才, 右上顎癌 上顎洞前壁の崩壊（矢印）
図 11 水平断層撮影（第3面）

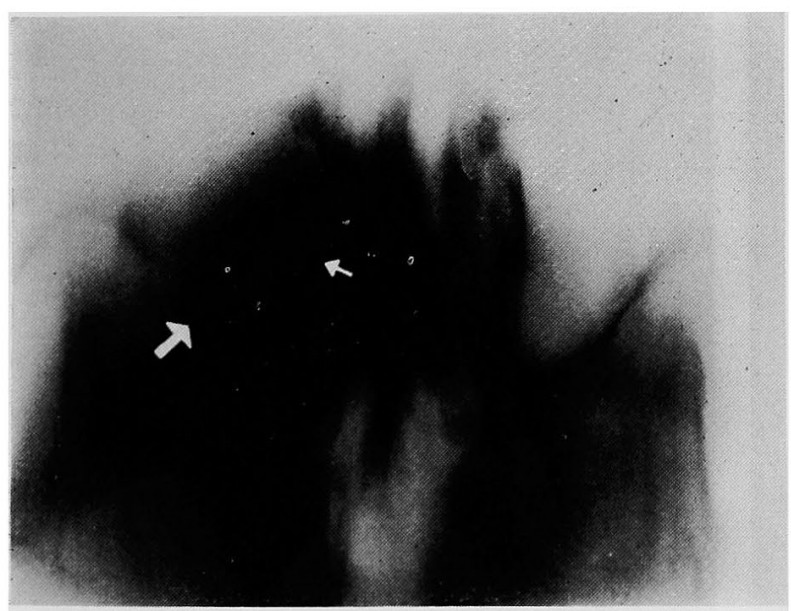

症例 9. T.I., 早 70 才, 右上䫇癌 上額洞側壁の崩壊（大矢印） 同内壁の崩壊 (小矢印)
図 12 涙道造影撮影 正面像

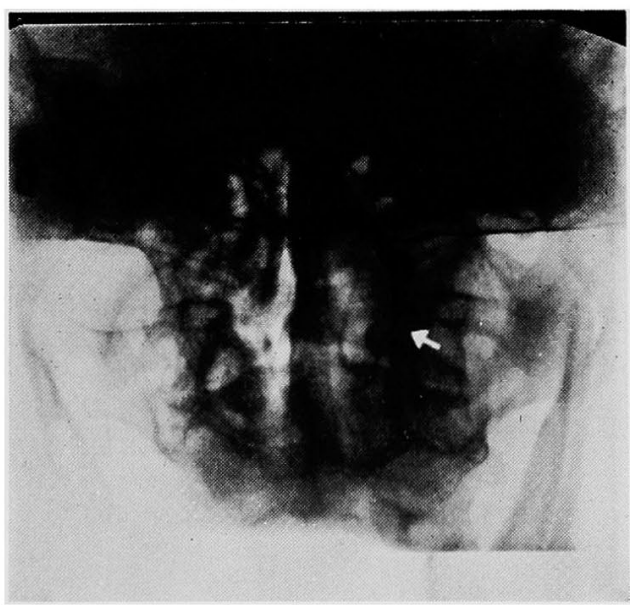

症例 6. O.M., 万 49 才 左上顎癌 鼻涋管の狭穹（矢印） 
相 原論 文 付 図 (IV)

图 13 源道造影撮影 㑡面像

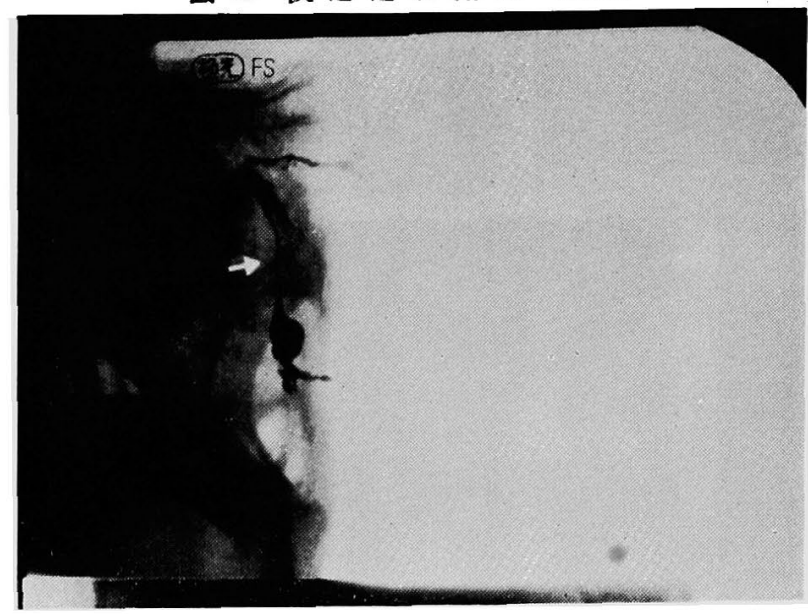

图 14 外頸動脈造影撮影 正面像

症 例図 12 と同

鼻湶管の狭 空 (矢印)
図 15 外頸動脈造影撮影 側面像

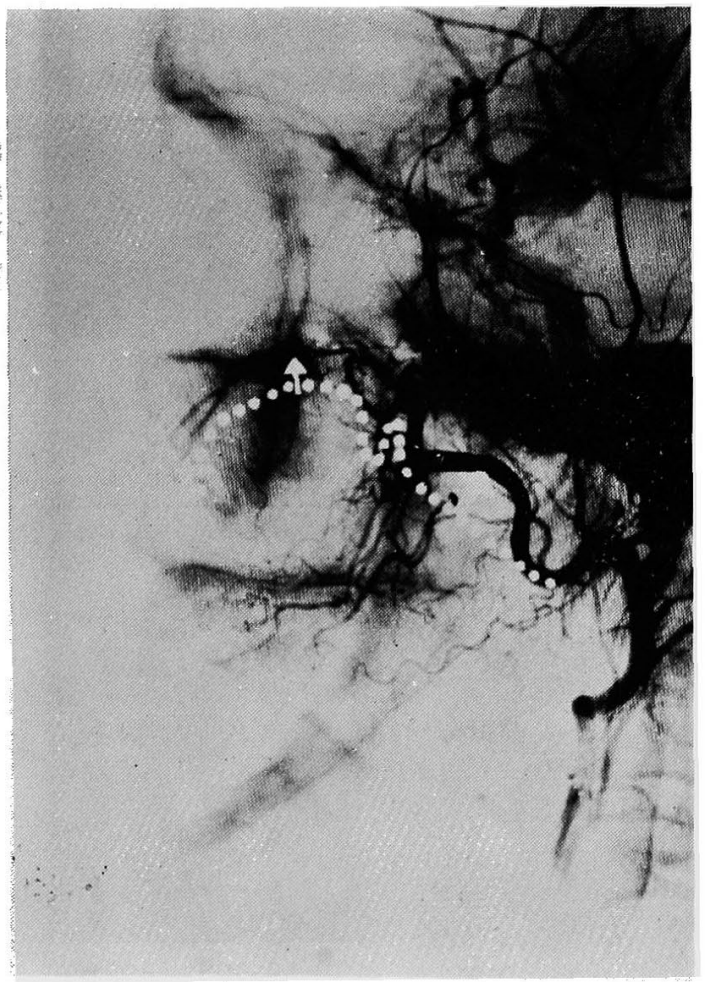

症 例 図 14 同

顎動脈の後上方枟位（大矢印）

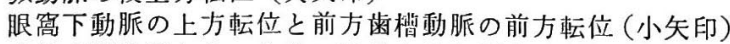
点線は顎動脈とその分枝の正常走行を示す

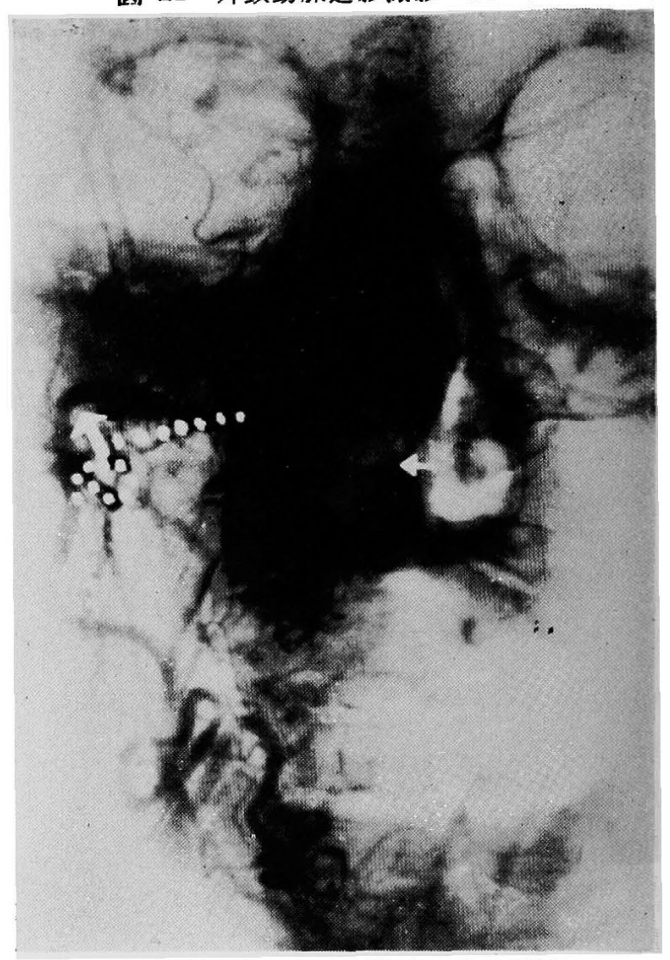

症例 12. C.H., 679才, 左上顎癌 顎動脈の側方転位（大矢印）

蝶口蓋動脈分枝の分布の䟱と蛇行の減少(小矢印) 点線は顮動脈の正常走行を示す

図 16 外頸動脈造影撮影 側面像

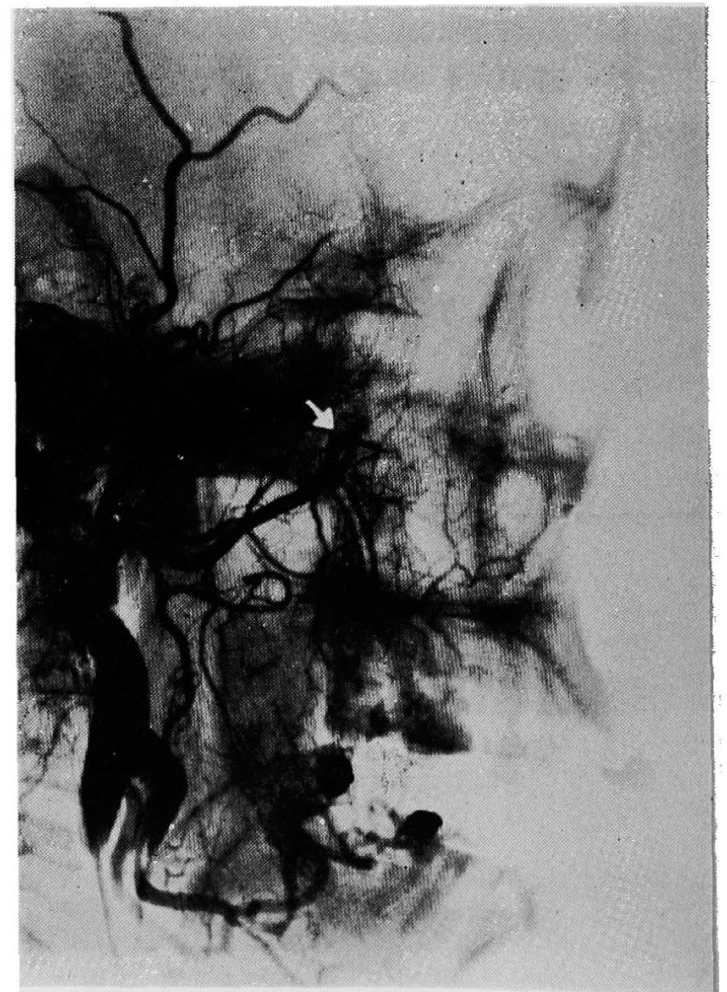

症例 8. T.N., 万60才, 右上䫇癌 眼窝下動脈の消失（矢印） 
M.: Über die Photographie der Nase und des $\mathrm{Ke}$ hlkopfes mittels Roentgenstrahlen, Laryngol. ges., 4; 12, 1896. 61) Scheier, $M .:$ Über die Verwerthung der Roentgenstrahlen in der Rhino-und Laryngologie, Arch. f. Laryngol., 6; 57, 1897. 62) Scheier, M.: Die Diagnostik der Empyem der nasalen Nebenhoehlen und das Roentgenverfahren, Arch. f. Laryngol., 21 ; 525, $1909 . \quad$ 63) Scheier, M.: Zur Untersuchung der Keilbeinhoehlen mittels Roentgenstrahlen, Arch. f. Laryngol., 24 ; 185, 1911. 64) Scheuneman, H. etc.: Angiographische Untersuchungen über die Architektonik der A. carotis externa, Fortschr. d. Kiefer u. Gesichts Chir., 108; 1957. 65) Scheuneman, H. etc.: Zur Methodik der Angiographie der A. carotis externa, Dtsch. Zahn u.s.w. Heilk., 28; 414, $1958 . \quad 66)$ Schrudde, $J$. etc.: Angiographische Untersuchungen bei Geschwulsten im Kieferbereich unter bsd. Beruchsichtigung d. Seriographie, Fortschr. d. Kiefer u. Gesichts Chir., 112; 1957. 67) Spiess, G.: Roentgenuntersuchungen der oberen Luftwege in Atlas und Grundriss der Roentgendiagnostik, Serausg. von F.M. Groedel M. München, $1909 . \quad 68)$ 高㤭 角次郎：脳血管撮影法, 1942. 69) 高須贺信夫他: 副奥腔疾患のレ線断層撮影について，正㖼，28；729， 1956. 70) 高須賀信夫：副舆腔のレ線断㒸撮影に就 $\tau$, 日耳·鼻，59；1127，1956.71) 高須賀信夫：上

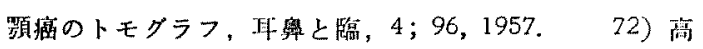
須賀信夫：進行方向上り見た上靧癌の Tomography，
日耳鼠，61；1123，1958。73) 寺田勝光：奥腔副鼠 腔に関寸る断層撮影法，日耳奥，62；2649，1957。74) Toennis, W.: Fortschritte in der Gehirnchirurgie, Jahr. kurse aerztl Fortb., 12; 1, 1933. 75) Vallebona, A.A.. A modified technique of roentgenographic dissociation of shadows applied to the study of the skull, Radiol. Med., 17; 1090, 1930. Waters, C.A etc.: Rontgentgenology of the accessory nasal sinuses describing a modification of the occipitofrontal position, Am. J. of Roentgenol., 2; 633, 1915.77) 山本宗路：上硕癌のレ線学的観察, 耳臨, 35；189，1940. 78）山本忠邦他：上䫑癌のレ 線検査，日耳鼻，59；1970，1956。79）吉川泰：上

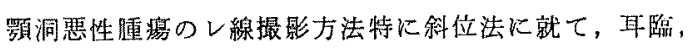
$36 ; 799,1941$. 80) 吉川泰他：上顎洞悪性腫㿑のレ 線撮影方法特に斜位法に就て, 耳踟, 37；1, 1942.

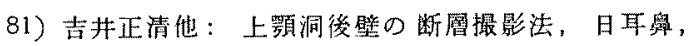
$64 ; 490,1961$.

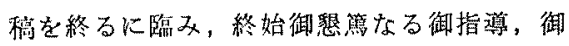
校閲を睗つた恩帥北村武教授に深甚なる謝意を

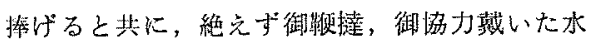
流搏士，目びに教室員各位に擪く御礼申し上げ ます

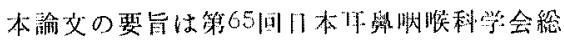
会において発表した。

(原和到萑 $=$ 明和 39.8 .24 日) 